\title{
North American Paleozoic Land Snails, With a Summary of \\ Other Paleozoic Nonmarine Snails
}

GEOLOGICALSURVEY PROFESSIONAL PAPER 1072
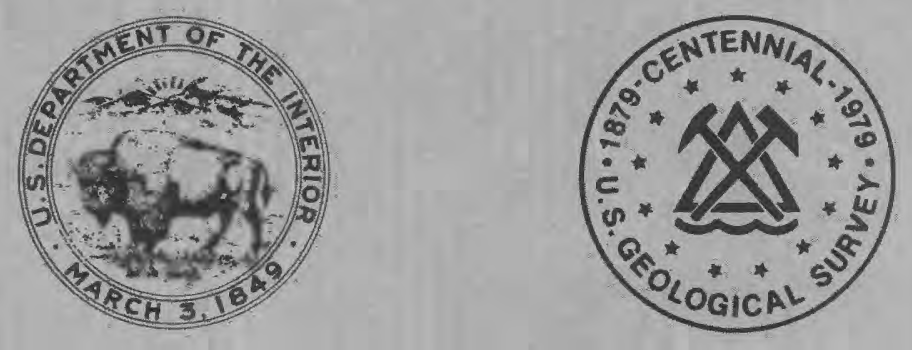


\section{North American Paleozoic \\ Land Snails, With a Summary of \\ Other Paleozoic Nonmarine Snails}

By ALAN SOLEM and ELLIS L. YOCHELSON

G E O L O G I A L S U R V E Y P R O F E S S I N A L P A P E R 1072

A redescription and review of Pennsylvanian

and Early Permian terrestrial forms, demonstrating the early diversification of the Pulmonata

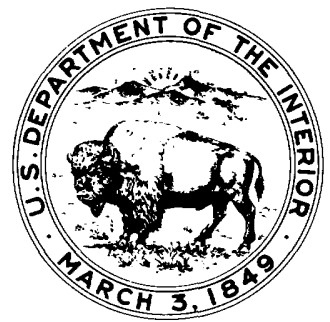

$\overline{\text { UNITED STATES GOVERNMENT PRINTING OFFICE, WASHINGTON: } 1979}$ 


\section{UNITED STATES DEPARTMENT OF THE INTERIOR}

CECIL D. ANDRUS, Secretary

\section{GEOLOGICAL SURVEY}

H. William Menard, Director

Library of Congress Cataloging in Publication Data

Solem, George Alan, 1931-

North American Paleozoic land snails.

(Geological Survey professional paper 1072)

Bibliography: p. 36-38.

Includes index.

1. Gasteropoda, Fossil. 2. Paleontology-Paleozoic. 3. PaleontologyNorth America. I. Yochelson, Ellis Leon, 1928- joint author. II. Title. III. Series: United States. Geological Survey. Professional paper ; 1072. QE808.S67 564'.3’097 $78-606004$

For sale by the Superintendent of Documents, U.S. Government Printing Office Washington, D.C. 20402

Stock Number 024-001-03197-3 


\section{CONTENTS}

\begin{tabular}{|c|c|c|c|}
\hline & Page & & Page \\
\hline 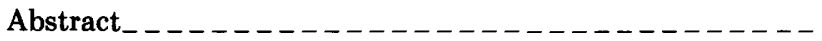 & 1 & Other Paleozoic nonmarine snails & 26 \\
\hline Introduction & 1 & Systematic summary & 28 \\
\hline Acknowledgments & 2 & Phyletic significance & 29 \\
\hline Earlier systematic work & 3 & Ecological significance & 31 \\
\hline Stratigraphic setting and local occurrence & 3 & Biogeographic significance & 33 \\
\hline Illinois and Indiana & 3 & Register of localities for Monongahela-Dunkard & \\
\hline Ohio, Pennsylvania, and West Virginia & 5 & gastropods & 34 \\
\hline New Brunswick and Nova Scotia & 6 & References cited & 36 \\
\hline Analysis and classification of taxa & 7 & Index & 39 \\
\hline
\end{tabular}

\section{ILLUSTRATIONS}

[Plates follow index]

Plate 1. Strophella, Anthracopupa, and ?Anthracopupa.

2. Protodiscus and Pupa.

3. Anguispira.

4. Dendropupa.

5-7. Anthracopupa.

8. Protodiscus, Anthracopupa, and Dendropupa.

9. Anthracopupa.

10. Dawsonella.

FIGURE 1. Shell structures in Dendropupa and a modern enid

2. Original illustrations of Dendropupa primaeva

3. Polished section of Anthracopupa ohioensis

4. Range of variation in barrier development of Anthracopupa ohioensis

5. Ontogenetic development of expanded lip and palatal ridges in Anthracopupa ohioensis

6. Shell-form differences in the pupillid and tornatellinid taxa

\section{TABLES}

TABLE 1. General correlation of parts of the Pennsylvanian and Permian between North America and Europe, showing the approximate positions of the stratigraphic groups from which land snails have been collected in North America _.

2. Size (in $\mathrm{mm}$ ) and shape variation in samples of Anthracopupa ohioensis Whitfield, 1881

3. Frequency distribution for shell height, shell diameter, height/diameter ratio, and whorl count in pooled samples of adult materials of Anthracopupa ohioensis Whitfield, 1881

4. Relation of shell height to shell diameter in all adult specimens of Anthracopupa ohioensis Whitfield, 1881

5. Relation of shell height to whorl count in all adult specimens of Anthracopupa ohioensis Whitfield, 1881

6. Systematic list of the Paleozoic land snails 


\title{
NORTH AMERICAN PALEOZOIC LAND SNAILS, WITH A SUMMARY OF OTHER PALEOZOIC NONMARINE SNAILS
}

\author{
By Alan SOlem ${ }^{1}$ and Ellis L. YOCHELSON
}

\section{ABSTRACT}

Land snails from the Paleozoic of North America are known from the coal fields of eastern Canada, from the Dunkard basin west of the Allegheny Mountains, and from the western margin of the Illinois basin. The earliest finds were made about 125 years ago; essentially no new information has been recorded for a century.

Large collections of Anthracopupa from the Dunkard basin sparked inquiry into the land snails from the other two areas. Studies using the SEM (scanning electron microscope) have provided considerable insight into microdetails of shell structure, which allow systematic assignment of these gastropods. All may be assigned to extant families, except one, for which insufficient material allows only superfamily assignment.

The prosobranch Dawsonella is confirmed as being a terrestrial neritacean gastropod. To date, it is known only from the upper Middle Pennsylvanian of Illinois and Indiana. All the other Paleozoic land snails are stylommatophoran pulmonates; their current classification as nonmarine cyclophoraceans is not correct.

Restudy of material from the Joggins section of Nova Scotia indicates that representatives of two ordinal groups of pulmonates appeared simultaneously in upper Lower Pennsylvanian strata; the oldest land prosobranch is found in only very slightly younger rocks. Zonites (Conulus) priscus is reassigned to the new genus Protodiscus in the extant family Discidae. Dendropupa is placed within the family Enidae, Anthracopupa is placed in the family Tornatellinidae, and "Pupa" bigsbii is assigned to the superfamily Pupillacea. All four of these family-level taxa are diverse and belong to two orders within the superorder Stylommatophora, heretofore considered a derived rather than an ancestral stock.

Anthracopupa ohioensis Whitfield is a highly variable species, and two other species Naticopsis (?) diminuta and A.(?) dunkardona, both named by Stauffer and Schroyer, are placed in synonymy with it. To obtain taxonomic data to support the family placement of Anthracopupa, growth forms of modern pupillid and tornatellinid snails have been distinguished. The apertural barriers in Anthracopupa are identical in placement and growth pattern with those of living Tornatellinidae and independently confirm the family placement derived from study of the general form. One new species, A. sturgeoni, has been named.

Anthracopupa is found most commonly in thin limestones interpreted as having been deposited in pools into which the small shells floated. Dendropupa is most commonly found in erect tree stumps that were covered by rapid sedimentation. Both environments are similar to those in which the shells of allied living species may be found today, and the fossils support environmental interpretations made entirely from lithology.

A survey of the few European occurrences of Paleozoic land snails indicates that both Anthracopupa and Dendropupa occur in Lower Permian strata; Anthracopupa is known from beds as old as

'Department of Zoology, Field Museum of Natural History, Chicago, Ill. 60605.
Westphalian B. These genera cannot be used for determining the Carboniferous-Permian boundary. Both the long local stratigraphic range of $A$. brittanica and $D$. vetusta reported in the literature and the moderately long range and great variability of $A$. ohioensis suggest that the land snails have little stratigraphic utility.

On the other hand, the occurrence of these land snails in the late Paleozoic of the Northern Hemisphere provides further fossil evidence suggestive of a closed Atlantic Ocean at that time. A comparison of the Paleozoic and the present distributions of land-snail families on both sides of the Atlantic provides some interesting data on geographic shifts of organisms. Finally, the assignment of the earliest land snails to extant taxa at the family level indicates that the subclass Pulmonata has been very conservative in its evolution after initial radiation.

A few notes on Paleozoic freshwater snails complete this survey.

\section{INTRODUCTION}

The restudy of type specimens, analysis of significant new collections of Anthracopupa from Ohio, and examination of diverse materials from other areas of the world have permitted us to prepare this detailed revision of the North American Paleozoic land snails and to summarize the probable affinities, stratigraphic significance, and biogeographic implications of all the Paleozoic nonmarine snails. SEM (scanning electron miscroscope) photographs of several taxa have revealed details of structure in the fossils that permitted assignment of the Paleozoic species to extant family groupings. One plate (pl. 1) documents types hitherto illustrated by drawings and supplements the plates of SEM photographs that illustrate shell structures.

Representatives of three orders and five families of land snails appear essentially simultaneously in the fossil record of the Pennsylvanian. These families persist today, thus demonstrating that in the early late Carboniferous, the land snails had achieved a high and stable level of diversity. Only three additional orders of land snails are recognized today. One of these, the Systellommatophora, contains only shell-less slugs and has no fossil record. Land snails belonging to the other two orders, Mesurethra and Holopoda, do not appear in the fossil record until significantly later. 
The record of North American Paleozoic land snails is spotty. Several taxa (Dawsonella meeki (Bradley, 1872), "Pupa" bigsbii Dawson, 1880, and Protodiscus priscus (Carpenter, 1867)) are known either from a single locality or a limited time span. Other taxa belong to genera (Dendropupa and Anthracopupa) that range from Middle Pennsylvanian (Westphalian B) through the Early Permian, about 45-50 million years, and occur in both North America and Europe.

For several taxa, the original age assignments are no longer accepted. We have attempted to equate the age of type localities with present nomenclature. As currently known, the fossil genera cannot be used to determine stratigraphic boundaries. The few species that are abundant have long stratigraphic ranges. Collectively, the Paleozoic land snails do provide added evidence that Europe and North America were joined as a single landmass during this time.

We were able to examine one or more specimens of each of the previously described North American species, except Pupa primaeva Matthew (1895), which is known from only one specimen that we could not locate. Study of extensive new collections from the Monongahela and Dunkard Groups (Upper Pennsylvanian and Lower Permian) resulted in several changes in synonymy and in description of a new species, Anthracopupa sturgeoni. Less intensive study of European and South American material has enabled us to make additional stratigraphic and biogeographic comments.

Our method of analysis of the fossil shells has been first to interpret, so far as possible, the basic growth patterns, structures, and ontogenetic developmental sequences. We have then compared these patterns and structures with the comparable ones found in extant land-snail taxa. Many of the fossils are very well preserved. With the aid of the SEM, we could study extremely fine details of the shell. The availability of both juvenile and adult examples permitted the determination of some aspects of shell ontogeny. When details of both structure and ontogeny in the fossils are found to match exactly features that are now restricted to a single extant family-level unit, we have no hesitation in assigning the fossil species to the extant family.

In the main section of this report, we describe the individual fossil taxa, review their structure, and suggest their individual affinities. The sequence of species is arbitrary and coincides with groupings of illustrations. Formal diagnoses and descriptions of higher taxonomic categories are included with the analysis of the one species in that taxon for which we had the greatest amount of data. This departure from the conventional systematic sequence of higher to lower category is deliberate.

We then present a summary of the other Paleozoic nonmarine snails, which is incorporated into the sections on the phyletic, ecological, and biogeographic significance of our systematic conclusions.

This project is a joint one, Solem being responsible for the data on present-day mollusks and Yochelson, for the geologic data. Both contributed freely to the systematic work and conclusions.

\section{ACKNOWLEDGMENTS}

Type specimens of previously described species were generously lent for study by Roger L. Batten, American Museum of Natural History (AMNH), New York; Stig Bergström, Orton Museum, Department of Geology, Ohio State University (OSU), Columbus; and D. Alison, Redpath Museum, McGill University, Montreal, Canada. Additional materials were borrowed from the Redpath Museum and from the Illinois State Geological Survey, courtesy of Lois Kent.

We gratefully acknowledge the help and advice over the years of the following colleagues in assembling scattered literature and contributing geological and biological information: Michael Calver, Geological Survey of Great Britain, Leeds; Arthur Clarke, U.S. National Museum of Natural History (USNM), Washington, D.C.; Murray Copeland, Geological Survey of Canada, Ottawa; A. Cross, Western Michigan University, Kalamazoo; R. M. C. Eagar, University of Manchester, England; Laing Fergeson, Mount Allison University, Sackville, New Brunswick, Canada; S. M. Gasioroski and A. Gromczakiewicz, Pơlish Academy of Sciences, Krakow; John H. Hanley, U.S. Geological Survey (USGS), Denver; Radvan Horný, National Museum, Prague, Czechoslovakia; Russell Jacobson, Illinois State Geological Survey, Urbana; Hermann Jaeger, Humboldt Museum, Berlin; the late Boris Licharev, All-Union Geological Survey, Leningrad, U.S.S.R.; A. Logan, University of New Brunswick, Fredericton; J. P. E. Morrison, USNM; Bruce Runnegar, University of New England, Armidale, New South Wales, Australia; Thomas Phillips, University of Illinois, Urbana; Werner Vacecek, Krahuletz Museum, Eggenberg, Austria; the late Jon Weber, Pennsylvania State University; and Halina Zakova, Geological Survey of Poland, Kielce. Henry Berryhill and S. Schweinfurth, U.S. Geological Survey, guided the search for fossils in the Dunkard basin.

The SEM photographs were taken by Solem on a Cambridge S4-10 Stereoscan, ${ }^{2}$ purchased by the Field Museum of Natural History (FMNH), Chicago, with the aid of Grant 72-02149 from the National Science

\footnotetext{
2 Any trade names in this publication are used for descriptive purposes only and do not constitute endorsement by the U.S. Geological Survey.
} 
Foundation, whose assistance is gratefully acknowledged. The excellent photographic prints by Fred Huysmans were mounted for publication by Dorothy Karall and Elizabeth A. Liebman. Line drawings are by Elizabeth A. Liebman, Illustrator, Division of Invertebrates, Field Museum of Natural History. The assistance of Sharon Bacoyanis in library work and manuscript preparation and of Barbara Walden in compiling data was indispensible.

\section{EARLIER SYSTEMATIC WORK}

Dawson (1880) summarized previous work and added many new data. He treated six species from the following three localities: Coal-Measures at South Joggins, Nova Scotia (Pupa vetusta Dawson, 1867, Pupa bigsbii Dawson, 1880, and Zonites priscus Carpenter, 1867); Erian plant beds of St. John, New Brunswick (Strophites grandaevus Dawson, 1880); and below coal No. 6 near Petty's Ford, Vermilion River, Ill. (Pupa vermilionensis Bradley, 1872, Dawsonella meeki (Bradley, 1872). Whitfield (1881) named the genus Anthracopupa and described Anthracopupa ohioensis from near Marietta, Ohio; he also commented that Dawsonella had the aspect of the modern prosobranch family Helicinidae. Subsequently, Matthew (1895) described Pupa primaeva from the presumed Devonian Fern Ledges, Lancaster, St. John County, New Brunswick, and Stauffer and Schroyer (1920) described Anthracopupa(?) dunkardana, Naticopsis(?) diminuta, and Loxonema(?) parva from Permian rocks at Pleasant Grove, Belmont County, Ohio.

Starting with that of White (1883), several checklist summaries of Paleozoic land snails have been issued, and some systematic comments have been scattered in the literature, but they were not based on new information or new illustrations. Pilsbry (1926, p. 316-319) reviewed the pupilloid forms. He recognized that Anthracopupa might belong to the Tornatellinidae or the Ellobiidae and described the genus Maturipupa for Pupa vermilionensis, suggesting that it too might be a tornatellinid. He also indicated that Dendropupa vetusta might be an ancestor of the Urocoptidae and stated that Pupa bigsbii, Pupa primaeva, and Strophites grandaeva could not be classified on the basis of pubished descriptions and illustrations. Henderson (1935) placed Strophites, Dendropupa, Anthracopupa, and Maturipupa in the Pupillidae, put Zonites priscus in the Zonitidae, and put Dawsonella in the Helicinidae. Yen (1949) essentially followed Henderson, except in considering that Zonites priscus and Strophites grandaeva were of uncertain affinity.

Bradley (1870, p. 254) reported the occurrence of two kinds of small land snails in "The nodular lime- meeki, placing it next to the Helicinidae, had placed both Dendropupa and Strophella (=Strophites Dawson, 1880 not Deshayes, 1832) in a new subfamily of the Cyclophoridae, the Dendropupinae, and had placed Anthracopupa in a new subfamily, Anthracopupinae, of the Ellobiidae. Knight, Batten, and Yochelson $(1960$, p. 1279,1318$)$ accepted the Dawsonellidae as a family unit, but referred the various pupilloid forms, including Anthracopupa and Maturipupa, to the Cyclophoridae, retaining the subfamily Dendropupinae Wenz (1938). H. B. Baker (1963) commented on the improbability of Anthracopupa and Maturipupa belonging to the Cyclophoridae. Zilch (1959-1960, p. 64-65) followed Wenz and placed both genera in a subfamily Anthracopupinae of the Ellobiidae.

\section{STRATIGRAPHIC SETTING AND LOCAL OCCURRENCE}

The bulk of our material comes from three widely separated areas. Each contains coal beds of economic importance, and interest in the coals probably led to the discovery of Paleozoic land snails. Each region is in a somewhat different geologic setting. The first, Vermilion County, Ill., is on the west edge of the Illinois coal basin, where a repeated alternation of marine and nonmarine units first led to the concept of the cyclothem. The second region, the Dunkard basin is centered roughly on Belmont County, Ohio, and is characterized by lacustrine deposits. The third is the classic Joggins area of Nova Scotia and adjacent areas of New Brunswick, where an enormous thickness of terrestrial strata was deposited in a comparatively short time; interlayers of lacustrine sediments are present. The eastern Canada fossils are from strata dated as Westphalian B, equivalent to Middle Pennsylvanian age; the Illinois basin fossils are from the Kewanee Group of late Middle Pennsylvanian age; the Dunkard basin rocks are of Late Pennsylvanian to Early Permian age. By far the most fossil land snails are from the Dunkard basin, but this may reflect a lack of concentrated collecting for fossil land snails in the Illinois and eastern Canada areas.

Table 1 summarizes the general correlations between North America and Europe and indicates the approximate position of the stratigraphic groups that have yielded the specimens studied.

\section{ILLINOIS AND INDIANA}

Yen overlooked the fact that Wenz $(1938$, p. 435, 470) had erected a family Dawsonellidae for Dawsonella stone accompanying the fire clay of this seam $* * *$ at Petty's Ford on the Little Vermilion River, about four 
TABLE 1.-General correlation of parts of the Pennsylvanian and Permian between North America and Europe, showing the approximate positions of the stratigraphic groups from which land snails have been collected in North America

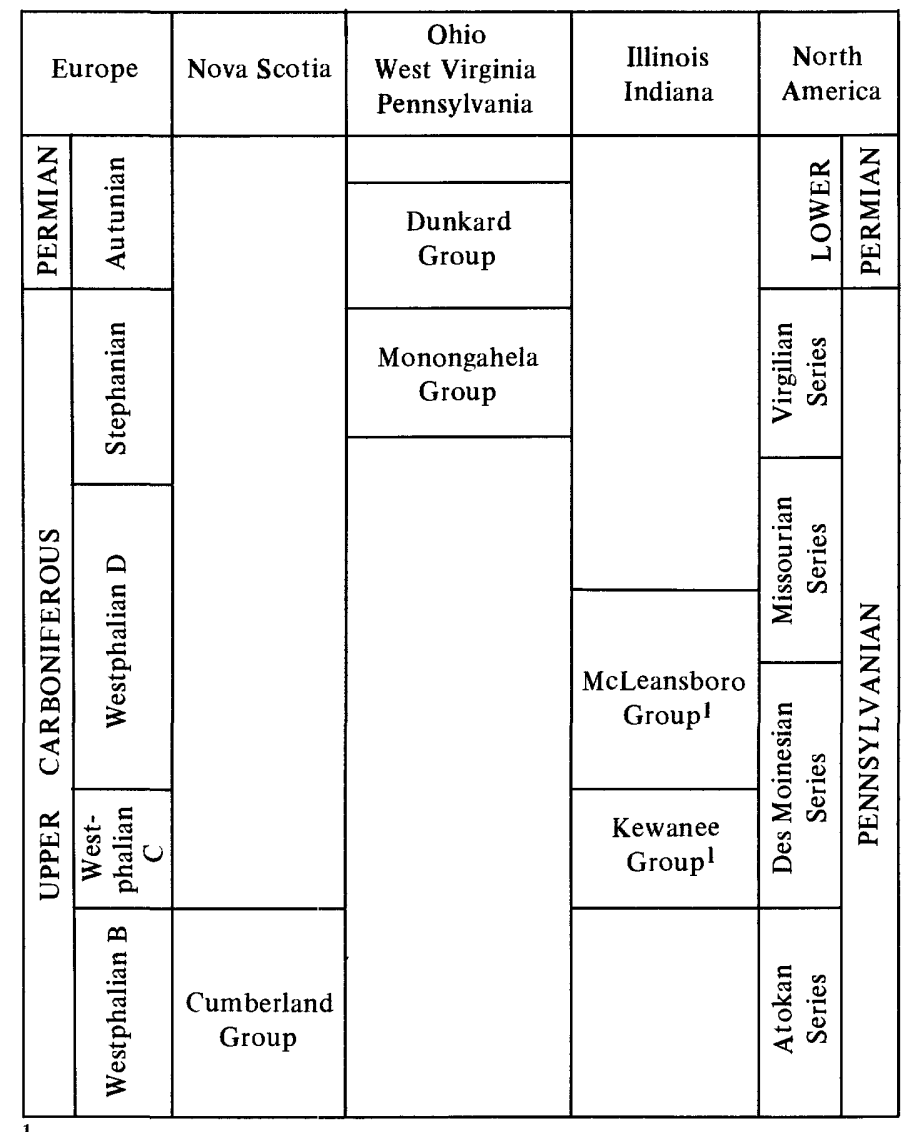

${ }^{1}$ As currently used in Illinois and Indiana nomenclature.

miles below Georgetown, Ill. In his section, this fire clay with concretionary limestone was 5-20 feet $(1.5-6 \mathrm{~m})$ thick. Bradley (1872) indicated later that this was "*** the concretionary limestone accompanying the underclay of coal No. $6^{* * *}$," a well-known unit in the Illinois section. No. 6 coal is the "Herrin Coal Member"3 of the Carbondale Formation (Willman and others, 1975, p. 191). The Spoon Formation and overlying Carbondale Formation constitute the Kewanee Group. This group forms the lower part of the Des Moinesian Series in Illinois; the McLeansboro Group forms the upper part of the Des Moinesian and extends up into the Missourian.

Bradley's collection almost certainly came from above the "Vermilionville Sandstone Member" ${ }^{3}$ and was either from the "Big Creek Shale Member" or more likely from the upper part of the "Spring Lake Coal Member" 3 of the Carbondale Formation, if those units extend eastward into Indiana.

\footnotetext{
'As currently used in Illinois nomenclature.
}

In 1927, J. M. Weller obtained land snails along the Little Vermilion River, a short distance above Petty's Ford in SE $1 / 4$ NW $1 / 4$ sec. 2, T. 17 N., R. 11 W., Vermilion County, Ill.; presumably these are topotypes of Bradley's two species. At that time the area was an abandoned strip mine. In 1976, no stratigraphic section could be compiled at this locality.

In his original description of Anthracopupa ohioensis, Whitfield (1881, p. 127) noted receipt of specimens of the two species described by Bradley (1872) from John Collette, then State Geologist of Indiana. He later amplified this remark slightly (Whitfield, 1895 , p. 490), stating “*** specimens of the two forms from that State $* * *$," implying that the land snails came from Indiana. In a review of Whitfield types purchased by the University of California, Peck and McFarland (1954, p. 304, 306) recorded Dawsonella meeki (Bradley) and Pupa vermilionensis Bradley from "Carboniferous, Coal Measures, Little Vermillion River, Vermillion Co., Indiana"; the county name in Indiana has a double "l," but the river and Illinois county name have one "l."

In view of Whitfield's remark in 1881, the specimens now in California are probably those he referred to as being from Indiana, and probably they do not have the status of types. One specimen of each of Bradley's species was illustrated by Peck and McFarland (1954). If the specimen of Dawsonella meeki that they photographed is the same as that figured by Whitfield (1881, figs. 5, 6), then Whitfield did not accurately portray its features.

To the best of our knowledge, Whitfièld's remark is the only published report of Paleozoic land snails from Indiana. Confirmation that Paleozoic land snails are in Indiana was substantiated by J. M. Weller who made a collection from SW $1 / 4$, sec. $29, T .17$ N., R. 10 W., Vermillion County, Ind., years ago. In attempting to recover this locality, Russell Jacobson found another occurrence of gastropods in a strip coal mine along the Little Vermilion River in the center NE1/4, sec. 32 , T. 17 N., R. 10 W., Vermillion County, Ind. The limestone is about $15 \mathrm{~cm}$ thick, nodular, and brecciated. Gastropods do not appear on the surface but are seen abundantly when the material is sawed. The limestone is about $1.5 \mathrm{~m}$ below a coal thought to be coal no. 4 (Summum coal), and the limestone is designated the equivalent of the Breezy Hill Limestone Member of the Cabaniss Formation of Kansas (Shaver and others, 1970, p. 229). If the coal is correctly identified, this new locality is in the Petersburg Formation of Indiana usage and is slightly older than the occurrence in eastern Illinois.

Collections from Indiana and Illinois contain several times as many fossils of Dawsonella meeki (Brad- 
ley) as of $P$. vermilionensis. The limestone matrix appears slightly more fine grained than in most of the gastropod-bearing beds of the Monongahela and Dunkard Groups, though this may be a function of the degree of weathering.

Terrestrial gastropods, known from two other localities in Illinois, have never been documented. These fossils suggest that a study of the freshwater limestones of the Illinois basin would significantly increase the number of localities known to contain fossil terrestrial gastropods; such freshwater limestones tend to be neglected.

The first locality is in the center $\mathrm{N} 1 / 2$ sec. $27, \mathrm{~T} .7 \mathrm{~N}$., R. 10 E., Jasper County, Ill. The fossils are from an unnamed freshwater limestone about a meter below the "Reisner Limestone Member of the Mattoon Formation." That marine limestone is near the base of the "Mattoon Formation," and the formation is the youngest in the McLeansboro Group. Two poorly preserved Anthracopupa specimens and abundant specimens of Spirorbis were collected from this locality long ago.

The second locality, also one from which fossils were collected long ago, is on the south bank of Hodges Creek, northwest of Chester Field, SW $1 / 4$ sec. 30, T. 10 N., R. 9 W., Macoupin County, Ill. A field check indicated that this area is badly overgrown. The stratigraphic section is thinner and contains more marine units than the section in the eastern margin of the Illinois basin. Possibly the fossils come from a freshwater limestone in the greatly thinned interval between coal no. 6 (Herrin) and coal no. 4 (Summum) or, less likely, they come from below the Summum coal. These fossils are thus middle Des Moinesian in age. Poorly preserved Anthracopupa occur at this locality.

\section{OHIO, PENNSYLVANIA, AND WEST VIRGINIA}

The Dunkard basin is west of the Allegheny Mountains and is more or less bisected by the Ohio River. Erosion has truncated the margins; the basin may have extended to western Maryland as well as an unknown distance northeastward. It is a broad syncline in which rocks are essentially flat lying. Above the marine Conemaugh Group, of Late Pennsylvanian age, are the Monongahela Group, also considered Late Pennsylvanian in age, and the Dunkard Group, considered by various workers to be Pennsylvanian or Permian (Barlow, 1975). The strata in the upper half of the Dunkard, the Greene Formation, are considered by most workers to be Early Permian.

Exposures are moderately good in the Dunkard basin, and no major structural complications exist there.

\footnotetext{
${ }^{4}$ As currently used in Illinois nomenclature.
}

Because marine strata are absent in the Monongahela and younger beds, a great deal of reliance is placed on the various coal beds for correlation. Although a few miscorrelations in the past resulted from misidentification of coals in widely spaced sections, detailed mapping and more closely spaced sections (Cross and others, 1950; Cross and Schemel, 1956; Berryhill, 1963; Berryhill and others, 1971) have essentially eliminated stratigraphic errors of this sort.

About 1,000 m of strata is exposed in the Dunkard basin; it consists of coal, sandstone, freshwater limestone, and shale of several varieties. The area is readily interpreted as a swamp-lake complex into which rivers debouched. From southwest to northeast across the basin, deposits generally shift from terrestrial to aquatic. Because it has the thickest and most abundant limestone deposits, Belmont County, Ohio, appears to have been the most aquatic part of the basin.

The unit that has yielded the most gastropods is the Little Captina Limestone Member of the Monongahela Formation. This unit has been examined at various localities throughout $3,885 \mathrm{~km}^{2}$ of outcrop, and at most places it yields gastropods. The characteristic sequence of this member is a thin rubbly limestone a few centimeters thick at the bottom, then about $15-20 \mathrm{~cm}$ of shale, a massive more fine grained limestone nearly a meter thick, a shale, and a thin rubbly limestone on top. The thin limestones above and below the main bed have yielded specimens.

The lower limestone member of the Washington Formation in the lower half of the Dunkard Group is the source of the second largest number of fossils. In this member of the Washington, as in the Little Captina Limestone Member of the Monongahela, the rubbly limestone, not the main limestone unit, has yielded fossils. Perhaps the main limestone unit only appears unfossiliferous because it has not been as weathered as the rubbly limestone. Some of the rubbly limestones might be brecciated limestones formed from drying crusts of lime mud.

Yochelson (1975, p. 250) suggested that A. ohioensis was probably from the Little Captina Limestone Member of the Monongahela, although its origin in the Washington Formation cannot be ruled out. In either event, collections in the Field Museum of Natural History provide material from the general type area at both horizons.

The three species of gastropods, Anthracopupa (?) dunkardana, Loxonema (?) parva, and Naticopsis (?) diminuta, from the Dunkard Group that were described by Stauffer and Schroyer (1920, p. 144-145) all were obtained "from the shales at the base of the Lower Washington Limestone, one-half mile south of Pleasant Grove, Belmont County, Ohio." Yochelson 
visited this area several times without finding an outcrop of the "Lower Washington Limestone Member." Material from U.S. Geological Survey collections 24846-PC and 24855-PC is from the top of this unit, about a kilometer from the type locality.

\section{NEW BRUNSWICK AND NOVA SCOTIA}

More confusion has surrounded the age of land snails from Joggins, Nova Scotia, and St. John, New Brunswick, than has surrounded the age of those from the Illinois and Dunkard basins. The gastropods at Joggins were first found by J. W. Dawson and Charles Lyell in 1851. For decades they were considered to be as old as Devonian. The same illustration and figures were repeated by Dawson $(1855,1868)$ in various editions of "Acadian Geology" and elsewhere during the last century, but, since the specimens were first described, no further study of the specimens has been made. The one exception to this is the redescription and photographic reillustration by Knight (1941, p. 98-99, pl. 96, figs. 6a-6e) of Pupa vetusta, the type species of Dendropupa.

Dendropupa vetusta ranges locally through more than $610 \mathrm{~m}(2,000 \mathrm{ft})$ of the Cumberland Group.

The lowest bed in which Pupa vetusta occurs belongs to group VIII of Division 4 of my section of the South Joggins, and is between Coal 37 and Coal 38 of Logan's section, being about 42 feet below Coal 37. The next horizon, and that in which the shell was first discovered, in 1217 feet of vertical thickness higher, in group XV of Division 4 of my section. The shells occur here in erect Sigillariae, standing on Coal 15 of Logan's section. The third horizon is in group XXVI of Division 4, about 800 feet higher than the last. Here also the shells occurred in an erect Sigillaria (Dawson, 1880, p. 408-409.)

The collection at the Redpath Museum contains several hundred fragments of Dendropupa, all in dark-gray carbonaceous shale. The original occurrences of $D$. vetusta in hollow upright tree stumps suggest that these were preserved in place, quite unlike the floated shells in lacustrine limestones. Sedimentation was intermittent but rapid when it took place. Upright trees $9 \mathrm{~m}(30 \mathrm{ft})$ high are preserved (Poole and others, 1970, p. 294). Much of the Cumberland Group, especially the upper half, is relatively coarse.

Although several paleontologists have studied the fossils of the Cumberland Group, emphasis has been placed on the fossil plants. Bell (1944, p. 29) did note in passing that Dendropupa occurs in the Cumberland Group, of late Westphalian A or early Westphalian B Age. Copeland (1957, p. 14) assigned the Cumberland to Westphalian B.

Hacquebard (1972) correlated the Cumberland to Westphalian B with a high degree of confidence principally on the basis of spores. He also summarized the depositional history of the area and included an inter- pretive sketch showing the coal basins of northern Europe and eastern Canada as adjacent. Poole and others (1970, Chart II) correlated the Cumberland as late Westphalian A and Westphalian B, in part Atokan in the American sense.

In addition to Dendropupa vetusta, Dawson (1880) reported three land snails from the Joggins section. The form he referred to as "variety tenuistriata" occurred "Along with the ordinary form" of $D$. vetusta. He does not state clearly whether he differentiated this variety at all three stratigraphic levels where the species was collected. Except for a drawing of part of the shell surface, he did not illustrate the variety.

The second form, Pupa bigsbii, was named by Dawson $(1880$, p. 410$)$ for a few specimens “*** found in the erect trees of group XV at the Joggins, along with $D$. vetusta." Only one specimen was available for study, and it was free of matrix. We accept Dawson's statement of occurrence; presumably this form also was found essentially where it had lived, in a decaying tree which was covered by an influx of sediments.

The final species from Joggins, Zonites (Conulus) priscus Carpenter (1867), was recorded by Dawson $(1880$, p. 411,412$)$ as occurring in the lowest beds at South Joggins that produced $D$. vestusta (Group VIII). Upon excavation of the locality in an attempt to find a greater variety of fossils, Dawson found “*.** that the thin layer containing the land shells was not continuous but in limited patches." He found only a few Zonites and a bone fragment in the layer. "One or two crushed specimens have been subsequently found in the erect trees holding Pupa vestusta in group XV, but the species is extremely rare in comparison" (Dawson, 1880, p. 410). On the basis of the meager data supplied, we suggest that this might have been a thin lacustrine limestone of a local pond into which the snail shells floated from their habitat in and around large trees.

Land snails are exceedingly rare in the Fern Ledges at St. Jo'n, New Brunswick. No systematic reports of Paleozoic land snails in eastern Canada have been published since the report published by Matthew in 1895. In part, this lack of reports is probably due to geologists ignoring the snails because they are of little stratigraphic value. The land snails received a great deal of publicity during Dawson's lifetime; the publicity may have served to defer further investigation of them.

The age of gastropods in the Little River Group from "Plant bed No. 2" of the Fern Ledges at St. John, New Brunswick, is more poorly understood than is the age of those from the Joggins Section. The gastropods in the Little River Group were originally considered Devonian (Erian) and subsequently were reassigned 
to the Silurian. Stopes $(1914$, p. $3-8)$ has summarized the various age assignments for these beds. The Fern Ledges are now placed in the Little River Group of late Carboniferous age. Correlation of the stratigraphic units in the nonmarine basins of eastern Canada is extremely difficult, but apparently the flora is comparable with that of the lower part of the Kanawha Formation in West Virginia. If this correlation is correct, the beds at Fern Ledges are probably of Westphalian B Age and therefore virtually the same age as those of the Joggins area that yielded gastropods. The section at Fern Ledges is thinner than that at Joggins.

Pupa primaeva Matthew (1895, p. 99) was collected from "Dark gray shale of Plant Bed No. 2. Fern Ledges, Lancaster, St. John County, N.B.” Repeated unsuccessful attempts have been made to trace Matthew's material. One can infer from the description that only a single specimen was collected.

Matthew's (1895, p. 99) species "comes from the plant bed in which many years ago, the author found the species of Pulmonate described as Strophites grandaeva by J. W. Dawson." Strophella grandaeva (Dawson) is known from a single flattened specimen and is discussed on p. 14.

\section{ANALYSIS AND CLASSIFICATION OF TAXA}

Zonites (Conulus) priscus Carpenter, 1567

Plate 2, figures $1-5$; plate 8 , figures $1-2$

Zonites (Conulus) priscus Carpenter, in Dawson, 1867, p. 331-333, figs. a-c, e; Dawson, 1868, p. 385, fig. 150; Dawson, 1880, p. 411413, figs. 10, 11, 14d; Yen, 1949, p. 237; Yochelson and Saunders, 1967, p. 246.

Zonites priscus Carpenter, White, 1883, p. 453, 475, pl. 2, figs. $11-$ 12; Henderson, 1935, p. 155.

Pyramidula priscus (Carpenter), Pilsbry, 1895, p. xxxix.

Archaeozonites priscus (Carpenter), Grabau and Shimer, 1909, p. 822 , figs. $120 \mathrm{~h}-\mathrm{i}$.

No meaningful discussion of the systematic position of Zonites priscus has been given, except the brief comment by Pilsbry (1895, p. xxxix) that this species should be compared with Discus (= Pyramidula of 1895 usage) or Charopa. The suggestion by Yen (1949, p. 237) that this species might be a cyclophorid is unfortunate and relates to Yen's misinterpretation of Dawson's original drawings. Dawson's illustrations are excellent but included several assumptions as to structure that are not supported by SEM observations.

We were able to examine six specimens, three of which are illustrated here on plates 2 and 8 . The specimen illustrated by Dawson in 1867 (fig. b) and in 1880 (fig. 10) as a whole-shell view was designated as the holotype by Alison and Carroll (1972); it is catalogued as Redpath Museum 3116 (pl. 2, fig. 1). This specimen has $31 / 4$ whorls. Despite being crushed laterally, it is $2.63 \mathrm{~mm}$ in diameter. A paratype, Redpath Museum $3116 \mathrm{a}$ (pl. 8, figs. 1, 2), is the specimen used by Dawson (1867, p. 332 , fig. e; 1880 , p. 411, fig. 11) for the basal view. The maximum diameter of this specimen is 3.22 $\mathrm{mm}$. Dawson's figures of the shell base do not agree, as the earlier drawing (Dawson, 1867, p. 332, fig. e) shows that specimen with an extended columellar area and open umbilicus, whereas the later (Dawson, 1880, p. 411 , fig. 11) shows the columellar lip joining the preceding whorl without any trace of an umbilical opening. Examination of the specimen shows that the basal, columellar, and parietal areas have been destroyed and that the fossil is an internal mold (steinkern). Hence, no information is available concerning the exact structures in these areas. The third specimen (Redpath Museum $3116 \mathrm{~b}$, pl. 2, figs. 2-5) is a juvenile paratype having $2 \frac{1 / 4}{4}$ whorls; it is only $1.94 \mathrm{~mm}$ in diameter. The excellent preservation of this fossil permitted illustration of shell-structure details (pl. 2, figs. 2-5) and determination of the species affinities.

The other three examples are not illustrated. The specimen labeled "upper bed" is $2.43 \mathrm{~mm}$ in diameter but is badly crushed, the specimen labeled "erect tree" is too crushed to measure, and the final specimen is an external impression of a short section of the body whorl which shows details of sculpture but no other features. Presumably all three specimens represent paratype material.

The SEM photographs indicate that early interpretations of the sculpture were erroneous. Both P. P. Carpenter (in Dawson, 1867, p. 332, fig. c) and Dawson (1880, p. $411-412$, fig. $14 d)$ reported that the apical sculpture was continued onto the postapical whorls and that the major ridges had four to five microradial ridges between each pair. Because of the small size of the shells, the limits of optical equipment and illumination, and the lack of knowledge concerning the complexity of shell microsculpture that existed at that time, these early conclusions were reasonable approximations.

The apical sculpture (pl. 2, figs. 2-4) is distinctly different from the postapical. At very low magnification (pl. 2, fig. 1), the apical sculpture does appear irregularly radial, and when it is viewed from a low angle (upper right of pl. 2, fig. 2 and lower left of pl. 2, fig. 3), its obliquely radial aspects are emphasized. When viewed from an angle closer to the vertical (center and lower part of pl. 2 , fig. 2 and pl. 2, fig. 4), the radial elements show an irregular rugose aspect. The main radial elements are partly interrupted at seemingly regular intervals. The difference between this sculpture and the postapical sculpture is quite clear. 
The postapical sculpture consists of major radial ribs; most commonly, two or three microradial ridges are between each pair of major ribs (pl. 2, fig. 2 right and especially pl. 2, fig. 3 lower center). In addition, when viewed at high magnification and from an oblique angle (pl. 2, fig. 5), the sculpture in the suture suggests that a microspiral element probably was present. Particularly apparent in the third and fourth interstices from the bottom of the photograph are remnants of spiral ridges at regular intervals. The sutural sculpture of heavily sculptured shells characteristically shows least wear, even when other parts of the shells are significantly worn. Preservation of sculpture in this section of the body whorl suture is a fortunate accident, but it is not unusual. Recent shells that show an equivalent amount of wear have sculptural remnants of no greater prominence.

On the basis of these observations, the following points are critical in attempting to determine affinities: the apical and postapical sculptures are quite distinct from each other; the apical sculpture has a major oblique radial component that is interrupted over most of the apex; the postapical sculpture consists of major radial ribs and a small number of microriblets in between; and apparently a spiral microsculptural element is present on the postapical whorls, at least near the suture.

Although no comprehensive review of sculpture patterns in extant land snails exists, the combination of different apical and postapical structures and the presence of major sculpture and microsculpture on the postapical whorls fits the "endodontoid" complex of families. Zonitoids generally lack apical sculpture, except fine spiral lines or ridges, rarely have prominent major radial sculpture, and essentially never show microradial sculpture. Pupilloid taxa generally have apices that are smooth or have microspiral grooves, followed by postapical sculpture at most major radial ribs, even in the planulate taxa. The bulimulids, which are much larger and generally elongated, do have complex apical sculpture and a variety of post-apical sculptures, but apparently they do not have a combination of macroradial and microradial postapical sculpture.

Several minute helicoid taxa that at one time were classified as endodontoids have been shown by dissection to belong to other families, despite having combined macroradial and microradial postapical sculpture and distinctive apical sculpture. Solem (1977) reviewed the sculpture of Striatura, Punctum, Radiodiscus, and Planogyra, demonstrating differences in formation and detail that separate them from the endodontoid families Charopidae and Endodontidae, which have the most complex and conservative sculpture patterns of the endodontoid complex. The Endodontidae have a combination of major radials, microradials, and "squiggly" spiral sculpture on the apex (see Solem, 1973b, fig. 1; 1976) and have macroradial ridges, microradial ridges and minute spiral ridges on the postapical whorls. The Charopidae primitively have an apical sculpture of spiral cords, which subsequently may be overlaid by added radial elements; they also have a characteristic, very complex postapical sculpture of major radials, microradials, and spiral elements that buttress the microradials (see Solem, 1970, figs. 7-11). The Punctidae show a variety of elements, but normally these are periostracal in nature, are semideciduous, and rarely show microspiral elements; the apical sculpture most frequently consists of spiral elements only.

Previously, little attention has been paid to the sculpture in the Discidae, a Holarctic family. The sculpture in this family provides the key to understanding the apical sculpture and affinities of Zonites priscus. The limits of the family Discidae are defined elsewhere (Solem, 1978a). Pilsbry (1948, p. 566, fig. 303) pointed out that some discids had complex apical sculpture, but his illustration did not show their complexity. The sculpture of Anguispira picta (Clapp, 1920 ) is illustrated in plate 3 ; this species has marked apical sculpture, but the postnuclear sculpture is lost on the penultimate and body whorls (see Pilsbry, 1948, p. 589). At low magnification (pl. 3, fig. 3), the basic pattern of change from dominance of microelements on the early apex to the presence of only major radial elements on the postnuclear whorls is evident.

Examined at higher magnification, the details of this change can be worked out. The upper part of the apex (left third of pl. 3, fig. 1) has diagonal radial microriblets that at a later stage in life (lower left of pl. 3 , fig. 5) begin to be crossed by oblique incised lines, creating the checkerboard pustule effect seen on plate 3, figure 5. Near the tip of the apex (pl. 3, fig. 4, far left), the initial irregular anastomosing nature of the microradial sculpture can be detected. Shortly before the end of the first apical whorl (pl. 3, figs. 3,5), an overlay of prominent radial ribs begins, starting initially at the upper suture and extending not even to the midpoint of the exposed whorl surface. After the first dozen or so of these ridges, they reach all the way to the next suture. At the 11/4 -whorl mark (pl. 3, fig. 4), these radial ridges are sharply defined and very prominent. The microsculpture between the radial ridges has been slightly altered (pl. 3, fig. 6), the oblique element being greatly reduced in prominence. By the $1 \frac{1 / 2}{2}$-whorl point, a second shift has taken place; the oblique microsculpture once again is very prominent, and the pustules are quite marked (pl. 3, fig. 2). 
The apical sculpture in this species thus is composed of three basic elements, whose prominence shifts from one part of the apex to another. Initially, anastomosing, strongly retractive microradial riblets having very narrow interstices are present. These become clearly separate entities but are then crossed at essentially right angles by extremely protractive incised lines, turning the radial riblets into a checkerboard of pustules. Superimposed on this pattern is a rather gradual development of protractive radial ribs that are inclined at about a $45^{\circ}$ angle and are slightly curved. When this third element reaches full size, the oblique microelements are reduced in prominence, only to reappear near the end of the apex in full prominence.

The early postnuclear sculpture (pl. 3 , fig. 1 right, 3 , 4 far right, 5 left) consists of low rounded radial ribs that essentially are continuations of the superimposed apical radial elements, plus a few microradial riblets in between the major ribs.

Except for the third element of the apical sculpture, the radial ridges, and the absence of any microspiral postapical sculpture, the shell sculpture of Anguispira picta agrees with that of Zonites priscus. The pattern of interruptions to the oblique radials in the latter species (pl. 2, fig. 4) can be interpreted as the remnants of dissecting spiral lines under conditions of moderate wear. Thus, the sculptural elements of $Z$ onites priscus are identical with the basic pattern found in extant Discidae.

Because of the limited material and the fact that several specimens were crushed, the adult size and shape of Zonites priscus are difficult to estimate. The whorls of the holotype (pl. 2, fig. 1) increase rapidly in width. Their pattern resembles the whorl incremental pattern found in the modern New Zealand Flammulina von Martens, 1873, rather than the more regular, less rapid incremental patterns of the North American genera Discus Fitzinger, 1833, and Anguispira Morse, 1864. The sculpture on the last section of the body whorl in the holotype (pl. 2, fig. 1, right) is both crowded and irregular, which is typical of gerontic growth in most land-snail taxa. The major radials are close together and are somewhat irregular in shape, and no microradials are clearly visible. This specimen has $3^{1 / 4}$ whorls; thus, both the whorl count and the whorl incremental pattern of Zonites priscus are comparable with those of Flammulina. Because of great lateral crushing, the measured diameter of the holotype is only $2.63 \mathrm{~mm}$, whereas the measured diameter of the steinkern (pl. 8, figs. 1, 2) is $3.22 \mathrm{~mm}$. Probably Zonites priscus had a maximum shell diameter of about $3.5 \mathrm{~mm}$ and as many as $3 \frac{1}{2}$ whorls.

On the basis of the above data, we have no hesita- tion in assigning Zonites priscus to the Discidae and placing it in a new genus, described below.

Genus Protodiscus Solem and Yochelson, new genus

Type species.-Zonites (Conulus) priscus Carpenter, 1867.

Diagnosis.-Small, diameter 3-3.5 mm, shells having a relatively loose coiling pattern, whorl count $3 \frac{1 / 4}{4}$ to $3 \frac{1}{2}$, apex distinctly elevated. Apical sculpture of protractive radial ribs, probably interrupted by equally strongly retractive lines, appearing rugose when worn. Postapical sculpture of low, prominent, protractive radial ribs, two or three microradial riblets between each pair of major ribs, and microspiral ridgelets visible near the suture.

Discussion.-The name refers to the shell ornamentation that serves as a prototype for the sculpture found in modern Discidae. The fact that the apical ridges in Protodiscus are protractive, whereas those in the modern Anguispira are retractive, is not significant, in view of the shifting sculpture seen on the apex of Anguispira (pl. 3). The age and occurrence of the type and only known species were discussed on p. 6 .

\section{Pupa bigsbii Dawson, 1880}

Plate 2, figure 6

Pupa bigsbii Dawson, 1880, p. 410, figs. 5, 6; Pilsbry, 1926, p. 318. Pupa bigsbyi Dawson, White, 1883, p. 453, 456, 475, pl. 2, figs. $9,10$.

Dendropupa? bigsbii (Dawson), Henderson, 1935, p. 149.

Anthracopupa? bigsbii (Dawson), Yen, 1949, p. 235-238; Yochelson and Saunders, 1967, p. 31.

The two specimens on which this taxon were based have not been studied since their original description. We select as lectotype the larger specimen that was illustrated in figure 5 in Dawson (1880). It is catalogued as Redpath Museum 3122. The lectotype is $2.19 \mathrm{~mm}$ high and $1.18 \mathrm{~mm}$ in diameter and has about $4^{1 / 2}$ whorls remaining. The specimen is covered in back with a hard glue, but the front side is unobscured and is illustrated on plate 2, figure 6 . No trace of surface sculpture exists. Both the shell lip and the last part of the body whorl are completely missing. The part of the specimen farthest from the apex is a piece of shell, presumably part of the columellar lip; the shell height has been measured to this point. The specimen is very slightly flattened but probably not enough to distort the form significantly.

The very broad apex, curved spire contour, and sudden change to the more flattened left profile of the body whorl, are all features that are characteristic of the modern pupillids (see discussion of Anthraco- 
pupa and figure 6A). Species such as Gastrocopta tappaniana (Adams, 1842), G. pentodon (Say, 1821), various Pupilla, and particularly Vertigo (see Pilsbry, 1948 , p. 887, fig. 477 ; p. 930 , fig. 502; p. 945, fig. 509; p. 958, fig. 515) match the basic whorl contours. This pattern of spire shape is highly characteristic of the Pupillacea but is not found in the Tornatellinidae. Thus, we have no hesitation in placing Pupa bigsbii in the Pupillacea. Without knowing the apertural characters, we cannot assign it to any generic taxon. We consider that too little information is available to warrant establishing a new genus for it. We have no doubts that it does represent a distinct generic unit, but we cannot characterize a genus adequately.

Another specimen studied by Dawson (1880, fig. 6) is catalogued as Redpath Museum 3122a. It is imbedded in matrix and measures $1.97 \mathrm{~mm}$ in height and $1.28 \mathrm{~mm}$ in diameter. Careful cleaning along one edge and a low-angle photograph (pl. 8, fig. 3) revealed traces of low radial ribs on the shell. On plate 8 , figure 4 , the whorl contours can be seen more clearly. The narrower apex, less curved spire, and presence of radial sculpture are very different from the characteristics of the lectotype. This specimen is an Anthracopupa, not "Pupa" bigsbii. We chose not to name it as a distinct species because it is a juvenile shell in a poor state of preservation, and the apertural features are unknown. However, the specimen is significant, for no other Anthracopupa are known from the Joggins, and this unique individual extends the range of the genus downward.

One additional uncatalogued specimen in the Redpath Museum is badly crushed and broken in two, then crudely glued back together. It appears to be "Pupa" bigsbii. Because no apertural features are discernible, it adds nothing to the concept of the species.

Dendropupa vetusta (Dawson, 1855)

Plate 4; plate 8, figure 5; figures 1a, b

Pupa vetusta Dawson, 1855, p. 160, fig. 12; Dawson, 1860, p. 270, figs. 1-3; Dawson, 1880, p. 405-409, figs. 1-4, 14, a, b; White, 1883, p. 453, 456, 475, pl. 2, figs. 1, 2.

Pupa vetusta variety tenuistriata Dawson, 1880 , p. 406, fig. $14 \mathrm{~b}$. Dendropupa vetusta vetusta (Dawson), Henderson, 1935, p. 149, 150.

Dendropupa vetusta tenuistriata (Dawson), Henderson, 1935, p. 150; Yochelson and Saunders, 1967, p. 65.

Dendropupa vetusta (Dawson), Pilsbry, 1926, p. 317, 318, pl. 32, figs. 21-24; Yen, 1949, p. 235, 238; Knight, 1941, p. 98, pl. 96, figs. 6a-e; Yochelson and Saunders, 1967, p. 64.

This species has been variously called a pupillid or a urocoptid similar to Microceramus (Dawson, 1880, p. 408; Pilsbry, 1926, p. 318), but no assured systematic position has been established. The data shown on plates 4 and 8 permit assignment to a family unit, al- though with less assurance than for Anthracopupa and Protodiscus.

The holotype of Dendropupa vetusta was designated by Knight (1941, p. 98). Three figured specimens at the Redpath Museum that are catalogued under 3119 are incorrectly designated as cotypes. The material we have examined has not been figured previously and was part of Dawson's uncatalogued collections. Though several hundred individuals are present, almost all are fragments. The material was excellent for studying sculpture and shell structure, but no quantitative study of size variation was possible.

The apex of the shell in this species (pl. 4, fig. 1) is about $2 \frac{1}{2}$ whorls in length, and the whorls are evenly rounded. It is not bulbous, and there is no significant change in logarithmic spiral. The sculpture on the apical whorls (pl. 4, fig. 2, lower right) consists of very fine radial incised lines that are quite crowded and follow the same angle as the growth wrinkles. Dawson (1880, p. 405-406) interpreted this sculpture as follows: "Nucleus round, smooth, the first turn below the nucleus marked with rows of little pits which gradually pass into the continuous striae." The worn areas having pitted spots on the surface of many specimens could easily be interpreted in this way. This observation by Dawson has been cited by most people who commented on the species and has greatly influenced subsequent speculations as to its affinities. We inspected several specimens that are quite well preserved but failed to detect any sculpture on the apex other than the very fine and crowded radial lines.

The postapical sculpture consists of relatively prominent radial ribs (pl. 4, fig. 2) that vary somewhat in size and spacing. Individual ribs, as seen in a fracture section (pl. 4, fig. 4), are shaped like broad inverted "V's" and extend from suture to suture. At their origin in the upper suture (pl. 4, figs. 2, 3), the ribs are blunt tipped and have no sign of expansion or crenulation effect. No microsculpture is visible, even at high magnifications. On the last part of the body whorl, the radial sculpture is reduced in size and quite crowded, almost disappearing behind the lip (pl. 4, fig. 6). The lip itself is broadly and gradually flared, as was well shown in Dawson's figure $2(1880$, p. 407). Seen from behind (pl. 4, fig. 6), the gradual expansion of the lip is evident. A drawing of an apertural fragment (fig. $1 B$ ) also illustrates the broad and gradual lip expansion. There is no heavy callus on the parietal wall or a continuous lip across the wall.

Preservation of detail is good in many specimens. The original shell material in the figured specimen has been replaced (cross section on pl. 4, fig. 4) by a single layer of crystals extending completely across the whorl profile. At places (pl. 4, fig. 5), highly unusual 

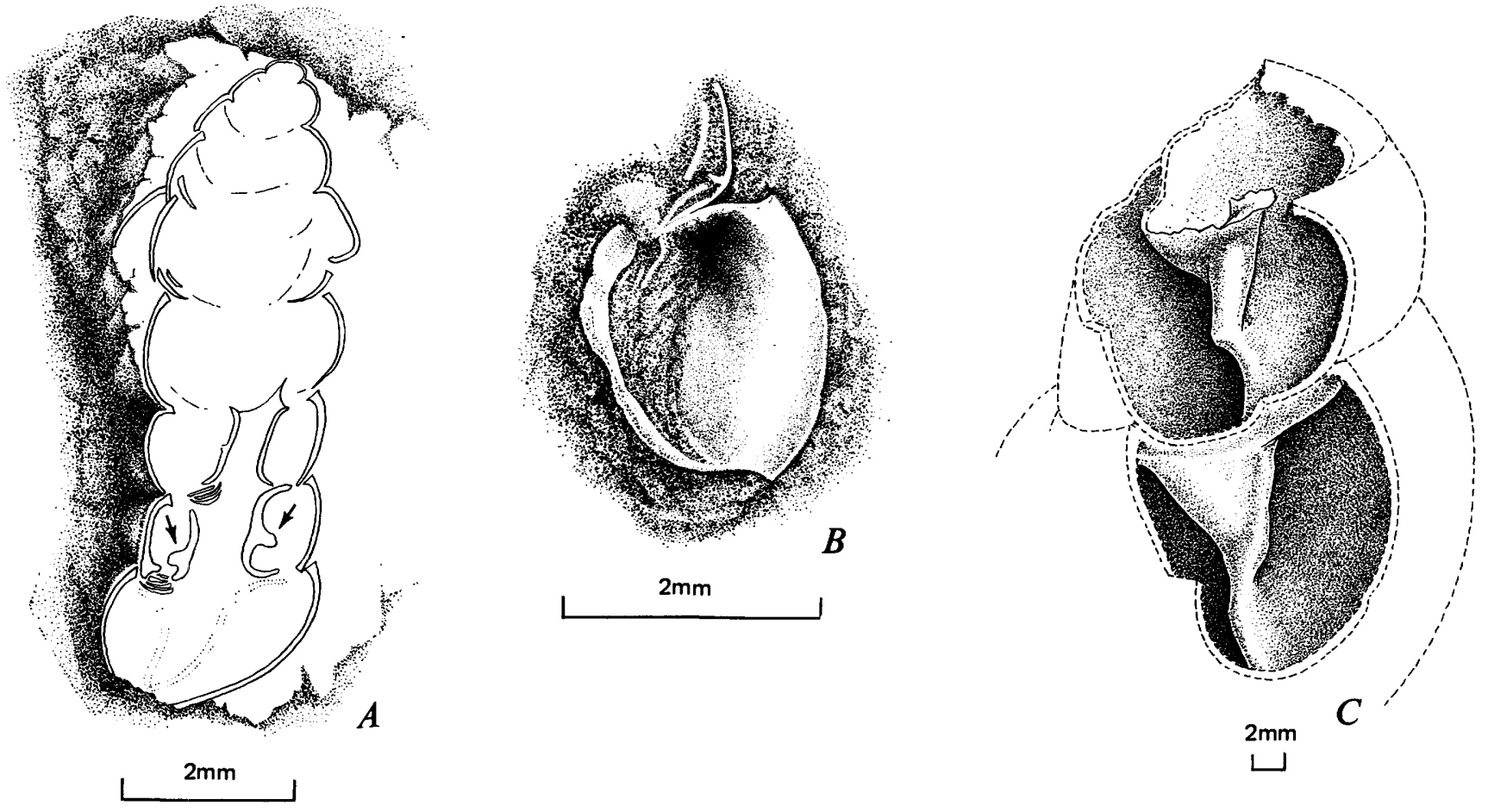

FIgire 1.-Shell structures in Dendropupa and a modern enid. $A$ $B$, Dendropupa vetusta (Dawson, 1855). Coal Measures, South Joggins, Nova Scotia. A, Polished section through partly crushed specimen. Arrows indicate columellar ridges; a large shell axis cavity is shown. Redpath Museum 15.024. B, Lip from another

crystal patterns are on the surface of the shell-replacement material. In other specimens (pl. 4, fig. 6), original shell material seems to have been retained, and shell-layer structures have beeen preserved. No study of the shell material was attempted, because knowledge of shell layers in comparable Holocene taxa is too inadequate to make meaningful comparisons.

The data obtained from an old polished cross section of a shell in the Redpath (fig. $1 A$ ) and study of an isolated columellar fragment (pl. 8, fig. 5) proved crucial in restricting the options for classifying $D$. vetusta. In figure $1 A$, only actual shell fragments are shown. The specimen had been partly crushed, and the polishing was done at an angle. Only the lower part of the columella is present; the upper columellar part was either lost before preservation because of crushing or, more probably, was ground away. We have no data concerning the diameter of the columella in the upper whorls in $D$. vetusta. A steinkern of the European D. zarecznyi Panow, 1936 (see p. 27) has the open columella confined to the lower half of the spire. We suspect this may be the situation in $D$. vetusta. The shell was polished from the back side, and thus the aperture would have been shown on the far left of figure $1 A$.

fragment, showing broad expansion, the thinness of the expansion, and pattern of junction to penultimate whorl. Redpath $\mathbf{M u}$ seum 15.032. $C$, Columellar ridge in a specimen of Buliminus labrosus labrosus Olivier, 1804. FMNH 54038.

The significant feature is that Dendropupa has a very wide, hollow columella, on which there are two raised ridges (arrows in fig. 1A). The ridge visible on the left side of the diagram is lower on the whorl profile than the one shown on the right side. The ridge on the right side also can be seen as a remnant on the next higher whorl on the left side. The SEM photograph (pl. 8, fig. 5) confirms that two such barriers existed and gives some idea as to their shape and angles in relation to the shell axis. Neither barrier apparently would have been visible from the aperture. Their presence had been postulated by Knight (1941, p. 98).

The internal barrier ridges on the columella are sufficient to eliminate possibility of placing Dendropupa in any prosobranch group such as the West Indian Pomatiasidae or the elongate cyclophoroid taxa. The presence of an operculum capable of shutting the shell aperture and the developed ridges on the interior of the columella are not compatible features. The small toothlike ridge or slit at the aperture in many cyclophorids and diplommatinids is a device to permit air flow past a closed operculum (see Solem, 1974, p. 178, 179) and in some species is intensified to form an actual breathing tube. These are very different adaptations from having on the columella actual long ridges that would prevent free movement of an operculum. 
Only higher mesogastropods and neogastropods having reduced opercula have columellar ridges. For this reason alone, the suggestion of Wenz (1938, p. 470) that Dendropupa might be a cyclophorid has to be abandoned.

Comparison with extant pulmonate families is required. Several families characteristically have elongated shells that are roughly equivalent to Dendropupa in shape and size. The Clausiliidae and most of the Pupillacea differ in having complex apertural barriers as adults or near adults. These barriers are clearly visible from the aperture and frequently edge the aperture itself. The Tornatellinidae differ in being generally smaller than Dendropupa, and, except in the Hawaiian radiation, the species have complex apertural barriers at all stages of growth. The Subulinidae and Achatinidae, except very rare individuals, lack a reflected lip, have different patterns of shell growth than Dendropupa, practically never have continuous radial ribbing, have the apical whorls proportionately much larger, and have the aperture occupying a much larger part of the shell length. The points outlined above are only the most obvious set of differences; many additional details of structure also are different. If unusual species in these families do develop features equivalent to those found in Dendropupa, the methods of constructing the characters are very distinctive and immediately distinguish those species from Dendropupa.

Three families-Bulimulidae, Urocoptidae, and Enidae-require more detailed comparisons with Dendropupa. The Neotropical and Austro-Pacific Bulimulidae, except such genera as those often clumped as Bostryx, have prominent and complex apical sculpture. This sculpture consists of both radial and spiral lirae, but never, so far as we are aware, incised radial lines. The genera grouped as Bostryx (sensu Zilch, 1959-1960) are found mainly in the Andean countries, Chile, Peru, and Bolivia; a few species of the subgenus Lissoacme are found in Ecuador and Argentina. Specimens of Bostryx have macroscopically smooth apices, do not have the lip expanded or reflected, and have irregularly rugose postapical sculpture. The whorls are mostly flat sided, the pattern of coiling is very tight (except in Lissoacme), and there are no barriers or expanded columellas. The resemblances to Dendropupa are only of a general nature in regard to shape; specific structural features are different. No other groups of Bulimulidae, except uncommon"freak" species, have this shape and whorl-increase pattern.

The Urocoptidae are a logical group with which to compare Dendropupa. Urocoptids generally have a radically expanded columella; the columella is armored by one to many spiral ridges, hooks, barriers, or corrugations. These features rarely are visible from the shell aperture. The shell generally has prominent, often sharply defined radial ridges after a smooth or weakly striated apex that may have radial ridges on the lower parts. Thus the expanded columella, columellar ridges, and radial ribs of Dendropupa suggest urocoptid affinities. The choice by Dawson (1880, p. 408) of Microceramus gossei (Pfeiffer, 1846) for comparison with Dendropupa is not unreasonable. However, Pilsbry (1903-1904, p. xvii, xviii) noted that the pattern of axial structures has evolved independently several times within the Urocoptidae and also in some achatinoid groups. His statement that "homologous regions of the shell or its axis have given rise to similar structures, wholly independently, in various phyla of the family," followed by a list of such convergences among genera, points out the improbability of making direct comparisons between Dendropupa and extant genera of the Urocoptidae.

Although the columellar expansion, ornamentation, and shell sculpture are similar in urocoptids and Dendropupa, in several features Dendropupa is quite different from the urocoptid growth pattern. Except in such genera as Microceramus and Holospira (sensu lato), the spire of urocoptids is normally decollated. The apex of the shell is bulbous and smooth to weakly ribbed, and the early pattern of spire growth is constricted, commonly leading to concave sides on the spire. The whorls are narrow and often exceed 20. Even in these genera that do not have a decollated spire, the pattern of a bulbous apex having narrow whorls and a constricted spire outline persists.

Equally important in differentiating Dendropupa from the Urocoptidae are their patterns of apertural structure. In nearly all groups of the Urocoptidae, the parietal wall either is detached from the penultimate whorl, forming a continuous lip around the aperture, or has a heavy raised callus. In all these taxa, either the palatal lip is simple to weakly expanded, or, if the palatal lip is expanded, it is abruptly reflexed and narrow. Only Microceramus and Pineria (Pilsbry, 19031904, pls. 1, 15, 20-27) depart from this pattern and have neither a parietal lip nor a heavy parietal callus. Even in these taxa, the lip structure differs greatly from that found in Dendropupa. At its upper margin, the palatal lip turns abruptly before inserting onto the penultimate whorl (Pilsbry, 1903-1904, pl. 26 for example), because the point of attachment is very low on the wall. Pilsbry (1946, p. 109) indicated that "Microceramus is a relatively unspecialized member of the primitive Antillean Urocoptid stock," but the growth 
pattern of the aperture and resultant insertion of the palatal lip is such that only lip extension is required to produce the detached parietal lip that is characteristic of most Urocoptidae.

In contrast, Dendropupa differs in the following ways: it does not have a bulbous apex; the spire sides are convex; the whorls are few in number (as many as nine); the whorls are relatively wide and have curved sides; the palatal lip inserts high and does not curve before inserting onto the penultimate whorl; no thick parietal callus is present; and the palatal lip is broadly and gradually expanded (see Dawson, 1880, p. 407, figs. 1, 2). The Urocoptidae have a basic growth "gestalt" that leads to decollation, detached parietal lip, and narrow whorls. Dendropupa does not share this basic pattern of shell form and growth. In Dendropupa, the special feature of an expanded columella having ridges duplicates a structure characteristic of the Urocoptidae, but this is a highly variable feature that has evolved several different times. The basic differences in shell form and growth pattern lead us to reject the idea that Dendropupa and the Urocoptidae are related forms.

The Enidae appear to be the most likely group with which to associate Dendropupa. A comparison of the illustrations in the latest monograph of the Enidae (Kobelt, 1902) with the urocoptid patterns indicates that the apertural shape, lip expansion and attachment, apex size, and whorl contours in enids closely match the basic growth form in Dendropupa and provide a distinct contrast to those characters typifying the Urocoptidae. The basic "gestalt" of shell form in the Enidae and Dendropupa is a close match, but few enids show major radial sculpture, and most enids have a narrow columella. Only in such taxa as Buliminus labrosus labrosus Olivier, 1804 (this report, fig. $1 \mathrm{C}$ ) is a ridge developed on the slightly expanded columella. Most enids do not develop a regular radial sculpture, but such sculpture has evolved sporadically.

Thus, in basic shell growth form and whorl characteristics, Dendropupa is similar to the extant Enidae; in having an expanded columella with two ridges and in having heavy radial sculpture, Dendropupa is similar to the extant Urocoptidae and differs from the Enidae. We give greater weight to the basic shell form and growth than to the details of the columella and shell sculpture. Therefore, we place the Dendropupinae Wenz, 1938, under the Enidae. The features that distinguish Dendropupinae from other subfamilies of the Enidae are the expanded columella with ridges and the regular radial sculpture on the postapical whorls.

Distributional differences between the extant Uro- coptidae and the Enidae are striking. The Urocoptidae has two centers of diversity-Mexico and the Greater Antilles. Members of both complexes extend short distances into North America and on the southern fringes of the Caribbean. Probable urocoptids (identified as Holospira) are known from the Eocene of both Wyoming and New Mexico and from the Upper Cretaceous of Alberta (Tozer, 1956, p. 82-84), but no South American fossil records exist for the Urocoptidae (Parodiz, 1969). The origin in time and space of the Urocoptidae is unknown, and its affinities, other than that it is loosely associated with the Bulimulidae, are unknown. The Enidae is primarily Palearctic and has extensive speciation in the Himalayas and Middle East and several groups radiating in both tropical Africa and South Africa. A few species are found in Indonesia; a peculiar group, Draparnaudia, is found in New Caledonia and the New Hebrides (Solem, 1959; 1962 , p. 219), and one genus is in northern Australia (Solem, 1964).

\section{Subfamily DENDROPUPINAE Wenz, 1938}

Description.-Columella expanded on lower spire, hollow, surmounted by one or more spiral barriers that stop well behind the aperture. Apex of shell has weak radial incised lines, postapical sculpture of inverted V-shaped radial ribs. Aperture without parietal lip or heavy callus, insertion of palatal lip into preceding whorl direct.

Discussion.-The expanded lower columella with raised ridges and the strong radial postnuclear sculpture are the main features separating the Dendropupinae from the other subfamilies of the Enidae. We recognize only one genus, Dendropupa Owen, 1859, with Strophella Dawson, 1859 (=Strophites Dawson, 1880, not Deshayes, 1832), a subjective synonym.

Genus Dendropupa Owen, 1859

Dendropupa Owen, 1859, p. 94. Type species: Pupa vetusta Dawson, 1859; monotypy. (see Knight, 1941, p. 98)

Strophites Dawson, 1880, p. 413. Not Strophites Deshayes, 1832. Type species: Strophites grandaevus Dawson, 1880; monotypy. Strophella Dawson, 1895, p. 84. Type species: Strophites grandaevus Dawson, 1880; monotypy.

Description.--Shell elongate, cylindrical, has about nine whorls when adult, spire sides convex. Apical sculpture of fine radial lines, postapical of prominent narrow radial ribs. Lip expanded, palatal margin inserting directly onto preceding whorl, no parietal lip or callus. Lower columella expanded, has raised ridges.

Discussion.-The type species is Pupa vetusta Dawson, 1859 , by monotypy, and it has been discussed 
in detail above. We include Strophites grandaevus Dawson, 1880, and Pupa primaeva Matthew, 1895, in Dendropupa, because the limited data on these two taxa provide no criteria by which they can be separated generically from the type species. In addition, the European species D. walchiarum Fischer, 1885, from France and D. zarecznyi Panow, 1936, from Poland fit quite well within our concept of the genus Dendropupa. The known distribution of Dendropupa thus extends from eastern Canada to Poland.

Dendropupa primaeva (Matthew, 1895)

Figure 2

Pupa primaeva Matthew, 1895, p. 98-99, pl. I, figs. 10a, b; Pilsbry, 1926, p. 318.

Dendropupa primaeva (Matthew) Henderson, 1935, p. 149; Yen, 1949, p. 236; Yochelson and Saunders, 1967, p. 125.

Despite repeated inquires during a period of several years, we have not been able to locate the single specimen on which this species was based nor to find any additional material that could be referred to this taxon. We have reproduced Matthew's original description (below) and illustrations (this report, fig. 2).

Matthew's $(1895$, p. 98, 99) description is:

Shell cylindrical, abruptly conical at the apex, increasing rapidly in the upper whorls. Whorls 6 ; sides of the whorls rather flat, upper edge sub-carinate; the last whorl about as wide as the shell, somewhat conical below, nucleus very small. Suture impressed. Aperture unknown. Shell surface smooth and shining.

Sculpture.-Surface ornamented with numerous sharp ribs, transverse to the whorl, about 20 visible on one-half of a whorl. These ribs are not all equally spaced or equally prominent; onesixth of a whorl may have them nearly twice as far apart as the rest. While quite distinct on the two last whorls, the ribs are less so than on the upper whorls of the shell.

Shell.-Length, $5^{1 / 2} \mathrm{~mm}$; width, nearly $2 \mathrm{~mm}$.

The original illustrations are reproduced here as figure 2. The whorl number, whorl contour, shell

$$
\text { Trans. R.S.C.. } 1894
$$

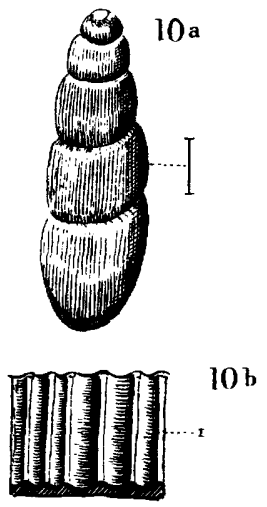

Figure 2.-Original illustrations of Dendropupa primaeva (Matthew, 1895, pl. I, figs. 10a, b). shape, size, and sculpture of radial ribs are consistent with this species being a small relative of Dendropupa vetusta. We can list no characters that would suggest generic separation. As pointed out by Matthew, $D$. vetusta has more whorls, but otherwise is very similar. Tentatively, this taxon is retained as a different species, although the reported diameter of $D$. primaeva (nearly $2 \mathrm{~mm}$ ) is only marginally below the observed range of $2.22-3.27 \mathrm{~mm}$ for $D$. vetusta.

\section{Dendropupa grandaeva (Dawson, 1880)}

Plate 1, figure 4.

Strophites grandaevus Dawson, 1880, p. 413-414, fig. 15; White, 1883 , p. 455, 475, pl. 1, fig. 1; Pilsbry, 1926, p. 319, pl. 32, fig. 16; Henderson, 1935, p. 149.

Strophella grandaevus (Dawson), Dawson, 1895, p. 84; Wenz, 1938, p. 470, fig. 1195; Knight, 1941, p. 341, fig. 5; Yen, 1949, p. 237.

Dendropupa grandaevus (Dawson), Yochelson and Saunders, 1967, p. 64 .

This species is known only from the holotype, catalogued as number 2384 in the Redpath Museum. It has not been restudied since its original description. The specimen is preserved apertural side downward on a thin slab of shale. This slab has broken so that a prominent crack runs diagonally across the lower two whorls (pl. 1, fig. 4). A photograph made many years ago and attached to the cardboard block holding the slab shows the crack as being somewhat narrower than it is now. The left margin of the specimen is broken, and the right margin is covered by a film of matrix; attempts to remove this without injury to the underlying specimen have been unsuccessful. Because neither margin of the shell can be seen, Dawson apparently mistook the preserved shape for the true form and his drawing suggests a bent shell. This interpretation has always been one of the enigmatic features of Strophella.

We interpret the holotype as representing a flattened periostracal fragment of a snail shell. There is no evidence of any thickness to the fossil. The low relief of the ribs is greater than would be expected, considering the degree of sutural crenulation in areas of whorl overlap. Dawson (1880, fig. 15) greatly exaggerated both rib height and degree of sharpness in rib contour. His drawing also gives a false impression of the shape, suggesting that the specimen had a curved columella. The appearance of this fossil is consistent with that of a decalcified periostracal shell remnant that has been pressed flat. This remnant probably included early postapical to lower spire whorls. The body whorl part behind the aperture may be partly present.

On the uppermost whorl, the intervals between ribs range from 0.12 to $0.14 \mathrm{~mm}$. No accurate measure- 
ments can be made on rib spacing on the second whorl. On the third whorl, the distances between successive parts of ribs generally increase along the direction of growth (right to left); the intervals (right to left) are $0.20,0.26,0.23,0.30,0.33,0.33$, and $0.36 \mathrm{~mm}$. On the last whorl, the intervals (right to left) are 0.33 , $0.30,0.36,0.40,0.33,0.40,0.36$, and $0.40 \mathrm{~mm}$.

Certain predictions concerning shell size can be made on the basis of whorl measurements and the intervals between ribs. In modern cylindrical land snails, the common pattern of rib spacing is for it to increase slightly and regularly as the whorl width increases regularly. If whorl width charges rapidly, rib spacing increases dramatically. When maximum shell diameter is approached and whorl width is not increasing, the intervals between ribs remain relatively constant. On the basis of these tendencies, one may infer that Strophella grandaeva may have had a narrow apex, and the early spire may have expanded rather rapidly in width. The penultimate whorl of the holotype still was widening slightly, as shown by the progressive increase in rib interval. On the last whorl of the holotype, the basically stabilized rib interval suggests that whorl width remained constant. From this point of growth, two patterns are equally possible. Either shell width stabilized and growth continued for a while before a lip formed, or, alternatively, gerontic growth and lip formation began almost immediately. In either growth pattern, it seems possible that an apex of one or two whorls was superimposed above the first preserved fragment.

Measurements of individual whorl heights, based on rib length from suture to suture, are: top whorl, $0.93 \mathrm{~mm}$; second whorl, $1.83 \mathrm{~mm}$; third whorl, 2.23 $\mathrm{mm}$; and last whorl (including basal extension), 3.16 $\mathrm{mm}$. The shell fragment has a cumulative total length of $8.37 \mathrm{~mm}$, although distortions have changed the actual tip to base length slightly. Allowing for a minimum of two low apical whorls, perhaps having a combined height of $0.5 \mathrm{~mm}$, plus another half whorl of body whorl growth adding $1.5 \mathrm{~mm}$, a total height of about $10.4 \mathrm{~mm}$ with $6 \frac{1}{2} 2$ whorls would be a minimum adult size. Growth of two additional adult whorls could be possible, and an adult height of as much as 15 $\mathrm{mm}$ is within the realm of speculation.

Clearly, this species falls near the size range of Dendropupa vetusta. Specimens of that species reach a height of $12 \mathrm{~mm}$ and have as many as nine whorls. The apparent major difference in shape is spurious. Indeed, if one allows for the extreme flattening of the specimen of $S$. grandaeva, it and specimens of $D$. vetusta are similar in profile. The two species do differ in the pattern and width of ribbing; Strophella gran- daeva shows much more rapid whorl increment.

We judge that generic separation cannot be maintained, and thus we place Strophella as a subjective synonym of Dendropupa. Knight, Batten, and Yochelson $(1960$, p. I318) had tentatively suggested this synonym, but they had not examined the type specimens of either genus.

\section{Anthracopupa ohioensis Whitfield, 1881}

Plate 1, figures 1-3, 8-10, 13, 14, 18, 19; plates $5-7$; plate 9 , figure 6 ; figures $3-5$

Anthracopupa ohioensis Whitfield, 1881, p. 126, figs. 1-4; White, 1883 , p. 456 , pl. 3 , figs. $5-8$; Whitfield, 1891 , p. 591 , pl. 12 , figs. 15-17; Henderson, 1935, p. 150; Yen, 1949, p. 236; Zilch, 19591960 , p. 63, fig. 202; Yochelson and Saunders, 1967, p. 31.

Anthracopupa(?) dunkardana Stauffer and Schroyer, 1920, p. 144-145, pl. 11, figs. 12-16; Yochelson and Saunders, 1967, p. 32. Naticopsis(?) diminuta Stauffer and Schroyer, 1920, p. 145, pl. 11, figs. 22-23; Tilton, 1930, p. 112, pl. 4, fig. A; Yochelson and Saunders, 1967, p. 140.

We have been able to examine the type of all three species considered here under $A$. ohioensis. The holotype (pl. 1, figs. $13,14,18,19$ ) of $A$. ohioensis is AMNH $8487 / 1$ and is the same morph as the typical rather squat form (fig. 4D), although the holotype reduced palatal ridges. The types of A.(?) dunkardana are cataloged in the Ohio State University Orton $\mathrm{Mu}$ seum as OSU 15151-15164. The largest and most elongated specimen, OSU 15161, is here designated as lectotype (pl. 1, figs. 11, 12), and the other three specimens are thus lectoparatypes. All examples have juvenile apertures and show no thickening of the lip or traces of the palatal barriers. The original figures of A.(?) dunkardana were misleading in that the columellar barrier was omitted. The types of Naticopsis(?) diminuta are OSU 15169 and OSU 15170. They are very young shells, still partly imbedded in matrix. The larger specimen, OSU 15170, is here designated lectotype (pl. 1 , figs. 1,2 ). It has a very wide apical angle and would have grown into one of the very short and broad adults, like that shown in figure 4D.

In addition to these types, we have about 100 specimens in the FMNH that were collected by P. D. Moore and associates and 500 specimens in the USGS collections (Yochelson, 1975).

Inclusion in one species of the diverse-appearing morphotypes represented by the three names and the examples in figures 3-5 requires justification. Because of the abundant material now available, variation both within individual collections (table 2) and in the pooled sample could be analyzed. Approximately 600 specimens were studied, of which 230 were adult and were sufficiently undistorted and complete to allow at least one measurement to be made. Shell height, shell 
diameter, and whorl count could be measured accurately in many specimens. The height/diameter ratio was calculated where possible. Because of flattening during preservation, broken edges on the whorls and spire, apical wear, loss of lip parts, and similar problems, each measurement could not be made on every specimen. When distortions or broken pieces prevented an accurate measurement, that measurement was not made on the specimen. For 226 specimens, shell height could be recorded; for 187 specimens, the whorl count was determined to the nearest eighth whorl; for 182 specimens, the shell diameter was measured; and for 179 specimens (of which both height and diameter had been measured), the height/diameter ratio was calculated. Partial crushing of the shell body whorl or general flattening during preservation was quite common, so that shell diameter commonly could not be determined. The remaining several hundred specimens were fragmentary, juvenile, imbedded in matrix, or too distorted to be measured. Table 2 lists the data of specimens from localities that have yielded more than a few scattered specimens well enough preserved to be measured.

The fossil localities are spread over a small geographic area relative to the range of many modern species and include deposits of slightly different ages. All samples contain adults that are very similar in size and shape. Mean whorl counts listed on table 2 are essentially identical, and the samples show an equally wide variation. Shells from the Nineveh Limestone Member, Greene Formation, were on the average a little smaller in diameter. A sample from the "Lower Washington Limestone Member," Washington For- mation, lacked the more elongated morph. The differences among samples, particularly in view of the large ranges in variations, are not significant. When the samples are pooled (table 3 ), the continuous nature of variation is evident. The height and whorl-count distributions, which are closely linked in expression, have an extended mode because of the variability, but no indication of any bimodality exists. Similarly, table 4 , showing the relation of shell height to shell diameter, and table 5 , showing the relation of shell height to whorl count, demonstrate normal distributions without any trace of bimodality. On the basis of size and shape variation, we cannot distinguish any subgroups within A. ohioensis.

Study of thin sections prepared from material in both the Little Captina Limestone Member and "Lower Washington Limestone Member" confirmed the interpretation of $A$. ohioensis shell structure inferred from the SEM photographs. In the cross-sectional view (fig. 3 ), one can see a very thin periostracal layer between the calcium layers of the shell; the existence of the periostracum indicates that it was not resorbed prior to the attachment of the lower whorls (see pl. 5, figs. 2-4 for the gap that exists where the periostracum was removed before preservation). The early whorls are not resorbed, a variable umbilical chink exists in the columella (ruled areas in fig. 3) during stages of growth, and the barriers do not extend up into the inner whorls.

The variability of $A$. ohioensis involves not only size and shape, but also the degree of development of both lip reflection and apertural barriers. Figure 4 shows four selected stages of barrier development. These

TABLE 2-Size (in mm) and shape variation in samples of Anthracopupa ohioensis Whitfield, 1881

[N, number of specimens. SEM, standard error of the mean]

\begin{tabular}{|c|c|c|c|c|c|c|c|c|}
\hline $\begin{array}{l}\text { Stratigraphic units } \\
\text { (collection nos.) }\end{array}$ & $\mathrm{N}$ & $\begin{array}{c}\text { Height } \\
\text { Mean } \pm \text { SEM } \\
\text { (range) }\end{array}$ & $\mathrm{N}$ & $\begin{array}{c}\text { Diameter } \\
\text { Mean } \pm \text { SEM } \\
(\text { range })\end{array}$ & $\mathrm{N}$ & $\begin{array}{l}\text { Height/diameter } \\
\text { ratio } \\
\text { Mean } \pm \text { SEM } \\
\text { (range) }\end{array}$ & $\mathrm{N}$ & $\begin{array}{c}\text { Whorl Count } \\
\text { Mean } \pm \text { SEM } \\
\text { (range) }\end{array}$ \\
\hline $\begin{array}{l}\text { "Lower Washington" } \\
(24846,24855-7)\end{array}$ & 18 & $\begin{array}{c}2.92 \pm 0.036 \\
(2.66-3.13)\end{array}$ & 9 & $\begin{array}{r}1.82 \pm 0.033 \\
(1.71-2.01)\end{array}$ & 9 & $\begin{array}{c}1.62 \pm 0.049 \\
(1.38-1.83)\end{array}$ & 8 & $\begin{array}{r}4.83 \pm 0.071 \\
\left(4^{1 / 2}-5^{1 / 8}\right)\end{array}$ \\
\hline $\begin{array}{l}\text { Nineveh } \\
(24827) \ldots-------\end{array}$ & 34 & $\begin{array}{l}3.03 \pm 0.076 \\
(2.66-4.14)\end{array}$ & 31 & $\begin{array}{l}1.72 \pm 0.042 \\
(1.35-2.17)\end{array}$ & 30 & $\begin{array}{c}1.75 \pm 0.031 \\
(1.39-2.09)\end{array}$ & 32 & $\begin{array}{r}4.81 \pm 0.047 \\
\left(4^{1 / 2}-5^{1 / 2}\right)\end{array}$ \\
\hline $\begin{array}{l}\text { Monongahela (Uniontown) } \\
(24851-2 \text { collections) }\end{array}$ & 16 & $\begin{array}{c}3.15 \pm 0.082 \\
(2.76-4.01)\end{array}$ & 13 & $\begin{array}{r}2.04 \pm 0.030 \\
(1.84-2.17)\end{array}$ & 13 & $\begin{array}{r}1.57 \pm 0.042 \\
(1.31-1.85)\end{array}$ & 13 & $\begin{array}{r}4.76 \pm 0.046 \\
\left(4^{1 / 2}-51 / 8\right)\end{array}$ \\
\hline $\begin{array}{l}\text { Little Captina } \\
\qquad(24854)\end{array}$ & 44 & $\begin{array}{l}3.24 \pm 0.036 \\
(2.73-3.78)\end{array}$ & 23 & $\begin{array}{r}1.88 \pm 0.026 \\
(1.61-2.11)\end{array}$ & 23 & $\begin{array}{c}1.71+0.033 \\
(1.45-2.02)\end{array}$ & 17 & $\begin{array}{r}4.90 \pm 0.049 \\
\left(4^{1 / 2}-5^{3 / 8}\right)\end{array}$ \\
\hline$(24840),--------$ & 15 & $\begin{array}{c}3.29 \pm 0.078 \\
(2.86-3.91)\end{array}$ & 16 & $\begin{array}{c}2.02 \pm 0.031 \\
(1.84-2.17)\end{array}$ & 14 & $\begin{array}{c}1.65 \pm 0.044 \\
(1.49-1.95)\end{array}$ & 14 & $\begin{array}{r}4.83 \pm 0.075 \\
\left(4^{1 / 2}-5^{1 / 4}\right)\end{array}$ \\
\hline (24836) --------- & 21 & $\begin{array}{c}3.17 \pm 0.075 \\
(2.66-3.75)\end{array}$ & 15 & $\begin{array}{r}1.86 \pm 0.030 \\
(1.71-2.04)\end{array}$ & 15 & $\begin{array}{c}1.71 \pm 0.037 \\
(1.46-2.00)\end{array}$ & 19 & $\begin{array}{r}4.86 \pm 0.051 \\
\left(4 \frac{1}{2}-51 / 4\right)\end{array}$ \\
\hline (24850) ---------- & 12 & $\begin{array}{l}3.21 \pm 0.070 \\
(2.76-3.59)\end{array}$ & 11 & $\begin{array}{c}1.99 \pm 0.038 \\
(1.78-2.17)\end{array}$ & 11 & $\begin{array}{r}1.60 \pm 0.045 \\
(1.45-1.98)\end{array}$ & 11 & $\begin{array}{r}4.94 \pm 0.052 \\
\left(4^{3 / 4}-5^{1 / 4}\right)\end{array}$ \\
\hline Scott's Cut (FMNH) & 47 & $\begin{array}{l}3.15 \pm 0.031 \\
(2.80-3.59)\end{array}$ & 47 & $\begin{array}{c}1.94 \pm 0.015 \\
(1.71-2.14)\end{array}$ & 47 & $\begin{array}{r}1.63 \pm 0.015 \\
(1.42-1.88)\end{array}$ & 38 & $\begin{array}{r}4.79 \pm 0.033 \\
\left(4^{1 / 2}-51 / 4\right)\end{array}$ \\
\hline
\end{tabular}


TABLE 3.--Frequency distribution for shell height, shell diameter, height/diameter, ratio, and whorl count in pooled samples of adult materials of Anthracopupa ohioensis Whitfield, 1881

\begin{tabular}{|c|c|c|c|c|c|c|c|}
\hline \multicolumn{2}{|c|}{ Shell height $(\mathrm{mm})$} & \multicolumn{2}{|c|}{ Shell diameter (mm) } & \multicolumn{2}{|c|}{ Height/diameter ratio } & \multicolumn{2}{|c|}{ Whorl count } \\
\hline$\overline{\text { Reınge }}$ & $\begin{array}{c}\text { No. of } \\
\text { specimens }\end{array}$ & Range & $\begin{array}{c}\text { No. of } \\
\text { specimens }\end{array}$ & Range & $\begin{array}{c}\text { No. of } \\
\text { specimens }\end{array}$ & Mean & $\begin{array}{c}\text { No. of } \\
\text { specimen }\end{array}$ \\
\hline $2.53-2.66$ & 4 & $1.35-1.48$ & 5 & $1.30-1.39$ & 3 & $4 \frac{1}{2}$ & 24 \\
\hline $2.67-2.83$ & 34 & $1.49-1.64$ & 15 & $1.40-1.49$ & 15 & $45 / 8$ & 27 \\
\hline $2.84-2.99$ & 49 & $1.65-1.81$ & 35 & $1.50-1.59$ & 47 & $43 / 4$ & 36 \\
\hline $3.00-3.16$ & 49 & $1.82-1.97$ & 77 & $1.60-1.69$ & 47 & $47 / 8$ & 36 \\
\hline $3.17-3.32$ & 35 & $1.98-2.14$ & 39 & $1.70-1.79$ & 31 & 5 & 31 \\
\hline $3.33-3.49$ & 30 & $2.15-2.30$ & 11 & $1.80-1.89$ & 20 & $51 / 8$ & 20 \\
\hline $3.50-3.65$ & 10 & -- & -- & $1.90-1.99$ & 10 & $51 / 4$ & 10 \\
\hline $3.66-3.82$ & 5 & -- & -- & $2.00-2.09$ & 5 & $5^{3 / 8}$ & 3 \\
\hline $3.83-3.98$ & 5 & -- & -- & -- & -- & $51 / 2$ & 1 \\
\hline $3.99-4.14$ & 5 & -- & -- & -- & -- & -- & -- \\
\hline
\end{tabular}

TABLE 4.--Relation of shell height to shell diameter in all adult specimens of Anthracopupa ohioensis Whitfield, 1881

\begin{tabular}{|c|c|c|c|c|c|c|c|c|c|c|c|c|}
\hline \multirow{2}{*}{\multicolumn{2}{|c|}{ Shell height (mm) }} & \multicolumn{11}{|c|}{ Shell diameter $(\mathrm{mm})$} \\
\hline & & $\begin{array}{c}1.35- \\
1.41\end{array}$ & $\begin{array}{l}1.42- \\
1.51\end{array}$ & $\begin{array}{c}1.52- \\
1.61\end{array}$ & $\begin{array}{c}1.62- \\
1.71\end{array}$ & $\begin{array}{c}1.72- \\
1.81\end{array}$ & $\begin{array}{l}1.82- \\
1.91\end{array}$ & $\begin{array}{c}1.92- \\
2.01\end{array}$ & $\begin{array}{l}2.02- \\
2.11\end{array}$ & $\begin{array}{c}2.12- \\
2.20\end{array}$ & $\begin{array}{c}2.21- \\
2.30\end{array}$ & Total \\
\hline $2.53-2.70$ & ---------- & -- & 1 & 1 & 1 & -- & -- & -- & -- & -- & -- & 3 \\
\hline $2.71-2.89$ & - - - - - - - - - - & 1 & 4 & 5 & 7 & 9 & 10 & 3 & 2 & - & -- & 41 \\
\hline $2.90-3.09$ & 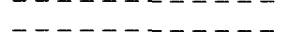 & -- & 3 & 2 & 2 & 5 & 17 & 13 & 5 & 2 & -- & 49 \\
\hline $3.10-3.29$ & 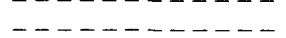 & -- & -- & -- & 2 & 7 & 7 & 11 & 10 & $\overline{5}$ & -- & 42 \\
\hline $3.30-3.49$ & $-------\cdots$ & -- & -- & -- & 1 & 2 & 5 & 10 & 5 & 2 & -- & 25 \\
\hline $3.50-3.68$ & - & -- & -- & -- & -- & 2 & 1 & 3 & 1 & -- & 1 & 8 \\
\hline $3.69-3.88$ & 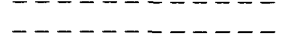 & -- & -- & - & -- & -- & 1 & 2 & 1 & -- & -- & 4 \\
\hline $3.89-4.08$ & $--\ldots$ & -- & -- & -- & -- & -- & -- & 1 & 2 & 4 & -- & 7 \\
\hline \multicolumn{2}{|c|}{ Total _. $\ldots \ldots \ldots$} & 1 & 8 & 8 & 13 & 25 & 41 & 43 & 26 & 13 & 1 & 179 \\
\hline
\end{tabular}

TABLE 5.--Relation of shell height to whorl count in all adult specimens of Anthracopupa ohioensis Whitfield, 1881

\begin{tabular}{|c|c|c|c|c|c|c|c|c|c|c|}
\hline \multirow[b]{2}{*}{ Shell height $(\mathrm{mm})$} & \multicolumn{10}{|c|}{ Whorl count } \\
\hline & $4^{\prime}:$ & 4 ix & $4{ }^{4}+$ & $4^{-}{ }^{H}$ & 5 & $5 *$ & $5^{\prime}+$ & $5^{3}{ }^{8}$ & $51 / 2$ & Tota \\
\hline $2.53-2.70-----------$ & 2 & 2 & - & - - & -- & - - & -- & -- & -- & 4 \\
\hline $2.71-2.89$ & 10 & 9 & 12 & 3 & 3 & 1 & -- & -- & -- & 38 \\
\hline $2.90-3.09$ & 8 & 10 & 11 & 11 & 5 & 1 & - - & - - & -- & 46 \\
\hline$-1-1-1-1-1$ & 4 & 4 & 8 & 13 & 8 & 7 & 1 & - & - & 45 \\
\hline $3.30-3.49$ & - & 2 & 3 & 6 & 12 & 6 & 1 & - - & - - & 30 \\
\hline $3.50-3.68 \ldots---\cdots----$ & -- & - - & 1 & 1 & 3 & 4 & 1 & -- & -- & 10 \\
\hline $3.69-3.88 \ldots \ldots-\ldots-\ldots$ & - - & -- & - - & 1 & -- & - - & 2 & 2 & -- & 5 \\
\hline $3.89-4.08$ & - - & - - & - - & - - & - - & 1 & 4 & 1 & 1 & 7 \\
\hline $4.09-4.27$ & -- & -- & -- & -- & -- & -- & 1 & -- & -- & 1 \\
\hline Total _ & 24 & 27 & 35 & 35 & 31 & 20 & 10 & 3 & 1 & 186 \\
\hline
\end{tabular}

features and those shown in figure 5 and on plate 5 , figures 1-3, demonstrate that shell shape and apertural features are not correlated. Even though many of the smaller squatter shells do have huge teeth and broadly reflected lips (figs. $4 C, D$ ), the same lip features and huge teeth occur in elongated slender shells (pl. 5, fig. 1). The development of the upper palatal ridge takes place very late in ontogeny, as discussed below, and the ridge may be absent from specimens having thin lips (fig. $4 B$ ). The lower palatal ridge varies from wide and bifurcated (pl. 5, fig. 2 ; figs. $4 C, D$ ) to narrow and single (fig. $4 A$ ). The inward sinuation of the lower palatal lip varies from absent (figs. $4 A, B$ ) through slight (pl. 5, fig. 1) to very prominent (fig. $4 C$ ).
Variation in thickness of the lip does correlate with the degree of palatal ridge development. If the lip is very thick and has grown inward, the palatal ridges are large. If the lip is thin and only slightly expanded, the palatal ridges are absent or only weakly developed. After initial reflection of the lip (fig. $5 A$ ), the subsequent growth is internal, narrowing the aperture by adding great thickness to the palatal wall and then building the palatal ridges. The lip thickening and palatal-ridge development are ontogenetic changes (figs. $5 A-C)$.

Despite attempts on our part, we could find no basis on which to divide this material into two or more taxa. Anthracopupa ohioensis appears to be a highly vari- 


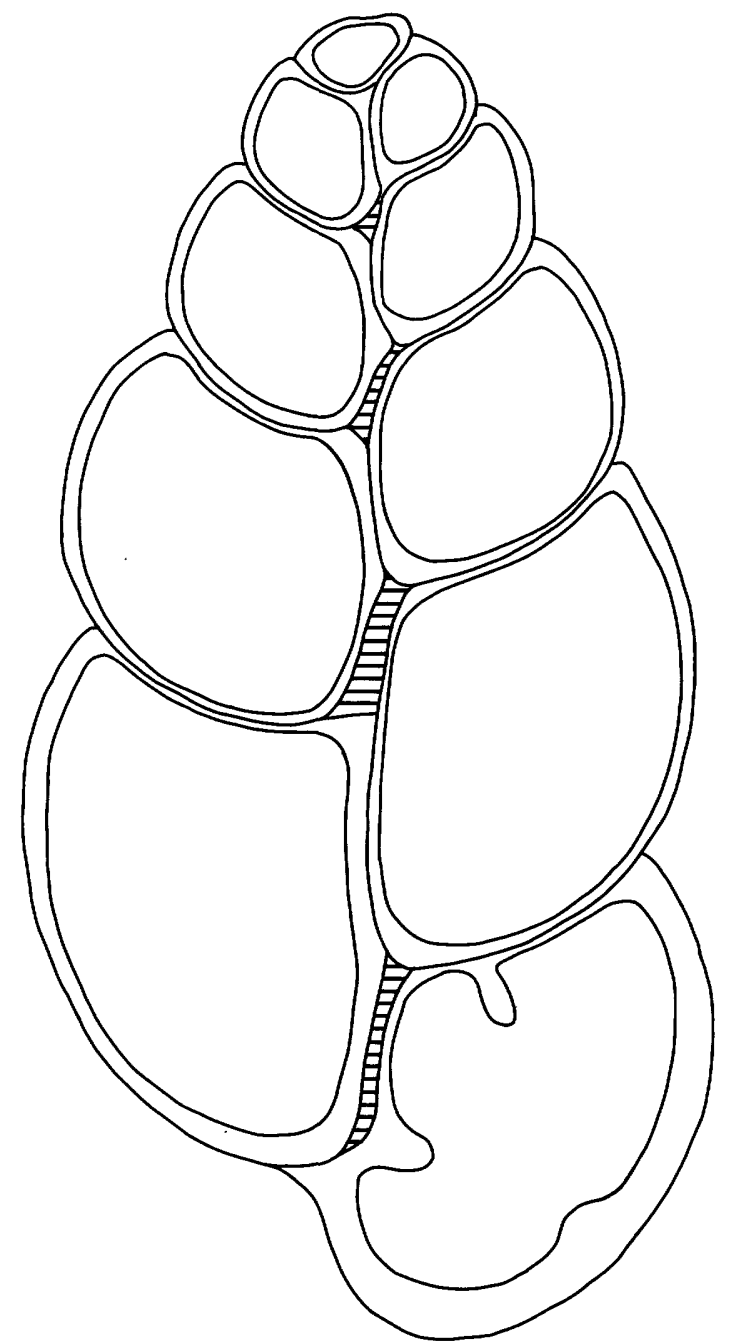

$2 \mathrm{~mm}$

FIGURE 3.-Polished section of Anthracopupa ohioensis Whitfield, 1881. Little Captina Limestone Member, Monongahela Formation, USGS locality USGS 24840-PC (USNM 242, 697). Ruled areas indicate hollow parts of columella. Periostracum is continued between new whorl attachment sections (see pl. 5, figs. 2-4, for an example of a specimen from which the periostracum has dissolved away). Note retention of the upper whorl partitions and slight remnant of basal ridge in section.

able species, as noted above, but it is not bimodal in its variation. Whenever more than 5 or 10 specimens were available from a locality, the same range in variation was found. We conclude that only one species can be recognized.

Preservation of the material varies greatly. The material includes badly crushed fragmentary specimens, steinkerns of the inside whorl profile, and recrystallized exact replicas of the shell surface. In one sample, from the "Lower Washington Limestone Member" in Ayers limestone quarry (USGS 24855-PC), a miracle of preservation permitted us to study shell details at nearly $10,000 \times$ (pl. 7, figs. 1-4). The following observations on structure were made about a variety of specimens and preservation types.

Commonly, specimens preserved in various ways were found at a single locality. Illustrated specimens from USGS 24855-PC indicate two extremes. These are easily separated visually by the presence (pl. 6 , figs. 1-3) or absence (pl. 5, fig. 1) of radial sculpture on the spire. Specimens without the radial sculpture showed different layers of crystals in what was originally the calcareous part of the shell (pl. 5, figs. 4-6) and no microprojections on the surface of the major barriers. Specimens having radial ribbing preserved showed only one type of crystallization (equivalent to that seen in Dendropupa vetusta, pl. 4, figs. 4-5) and many microprojections on the surface of the barriers (pl. 7, figs. 1-4). We interpret the mode of preservation of the specimens not having radial sculpture as loss of the periostracum without its replacement, followed by surface erosion of the barriers. We interpret the second type of preservation as replacement of both periostracum and calcareous layers by a single crystalline structure; exquisite surface details were preserved in the process. We have not studied the frequency of these two types of preservation or the mineralogy of the replacing mineral.

Examination of a ribless adult shell having well-developed barriers (pl. 5) shows that the parietal and columellar barriers (pl. 5, figs. 2-4) are relatively simple in structure and position and normally show no change from the locations and directions present in the juveniles (pl. 6, figs. 3-6). A speciment having a greatly distorted lip (figs. $4 C, D$ ) may also have the columellar barrier angled slightly upwards. In contrast, the palatal ridges are totally absent in juveniles (pl. 6, figs. 3-6), start to appear in specimens having newly formed lips (figs. $4 B, 5 A$ ) and are prominent only in gerontic shells (pl. 5 , figs. 2,3 ; figs. $4 C, D$ ). The lower palatal ridge is basal in position and normally is quite broad and has only a slight sinuation on its upper surface. The outer palatal ridge (pl. 5, fig. 3) commonly consists of two knobs connected by a lower, but still elevated, ridge.

The parietal and columellar barriers of the ribbed juvenile shells (pl. 6, fig. 1) are narrower than those of the gerontic individuals, and the columellar barrier shows a slightly curved tip (pl. 6, figs. 4, 6). The microstructure of the barriers is preserved to differing degrees. The surface radial sculpture on the shell spire is missing from the gerontic individual illustrated on plate 5, and apparently the surface layers of the bar- 


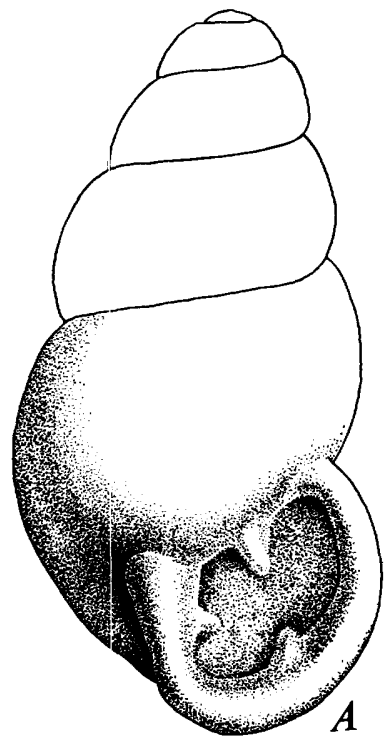

A

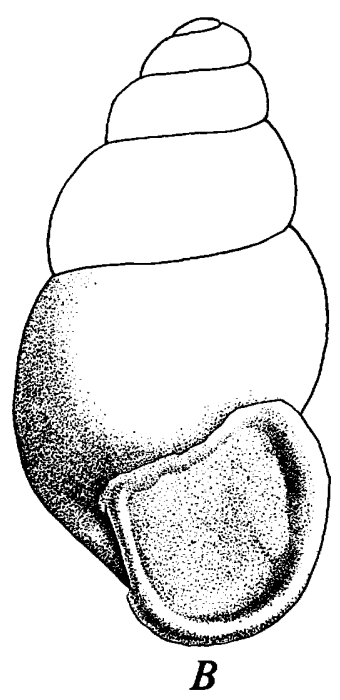

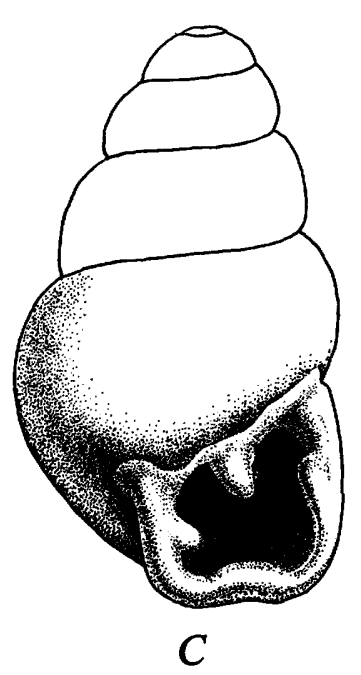

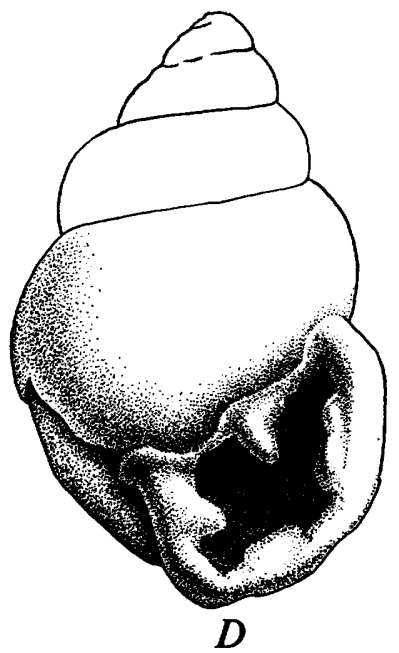

$2 \mathrm{~mm}$

Figure 4.-Range of variation in barrier development of Anthracopupa ohioensis Whitfield, 1881. "Lower Washington Limestone Member," Washington Formation. A, USGS 24857-PC. B, USGS 24855-PC. $C$, $D$, USGS 24846-PC.

riers also are absent (pl. 5, figs. 4-6). On plate 5, figure 4 , a crevice is discernible between the end of the parietal barrier with its continuing callus and the surface of the penultimate whorl. We interpret this crevice as representing a missing periostracal layer that had been dissolved after death and burial but before diagenetic modification of the shell layers had taken place. More detailed examination of the barrier edge (pl. 5, figs. 5-6) shows two different crystalline layers, an inner layer (left of pl. 5, fig. 5) consisting of large horizontal crystals, and an outer layer of vertical columnar crystals (pl. 5, figs. 5-6). This outer layer was covered by a second complex layer (see right part of pl. 5 , fig. 5), details of which could not be studied because of surface wear. The photograph fracture section was chipped during cleaning; hence, the two crystal layers were unworn.

Several specimens from Ayers quarry had the periostracal layers apparently intact at the time of preservation. Study of details on these specimens (see also fig. 3) produced critically important data in determining the affinities of Anthracopupa. The apical whorls are smooth, even at $205 \times$ magnification (pl. 6, figs. 1,2 ), whereas the postapical whorls (pl. 6 , figs. $2,3,5$ ) have a sculpture of low, rather closely spaced axial ribs. Remnants of this form of sculpture also were seen on the juvenile Anthracopupa that was part of the type lot of Pupa bigsbii (pl. 8, fig. 3, upper left side). The ribs are greatly reduced below the periphery of the whorls (pl. 6, figs. 3,5 ), and this perhaps explains the existence of the crevice mentioned above and shown on plate 5 , figure 4 . If the rib profile is very low or reduced below the periphery, resorption of the periostracal covering and (or) ribs is not necessary before growth of the next whorl. This contrasts with the situation in extant endodontoids, where rib and periostracal resorption on the lower part of the whorl is necessary preliminary to growth of the next whorl (Solem, 1973a, fig. 7). Preservation of these Anthracopupa seems to have involved replacement of both shell and periostracum.

The barriers in the specimens having preserved periostracum showed incredibly minute surface detail (pl. 7). An excised parietal barrier was mounted for SEM observation (pl. 7, fig. 1) in order to minimize electron charging interference. Matrix in the aperture (pl. 6, figs. 3, 4,6) charged badly, and higher magnification study of the parietal barrier would have been impossible without separating it from the matrix. The sides of the barrier have very few microprojections (pl. 7, fig. 2), and the top of the barrier is crowded with very large microprojections (pl. 7 , figs. 3,4 ); this pattern is neither accidental nor an artifact. In some recent Pupillidae, such as Vertigo morsei Sterki, 1894 (Solem and Lebryk, 1976, figs. 27-32), exactly the same pattern is seen; microprojections on the barrier tops are much larger than those on the lip edge and sides of the barriers. As is typical in most pupillids, the microprojections are roughly triangular (pl. 7, fig. 4). Even on a shell embedded in matrix (pl. 7, figs. 5, 

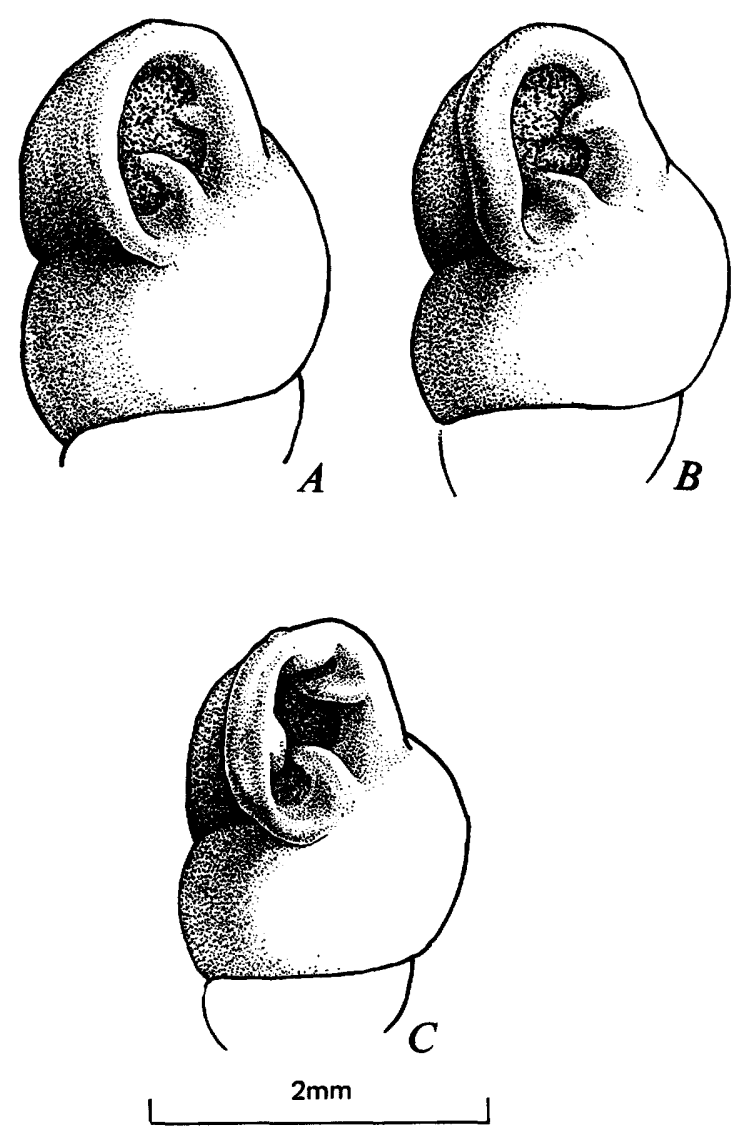

Figure 5.-Ontogenetic development of expanded lip and palatal ridges in Anthracopupa ohioensis Whitfield, 1881. $A$, Newly adult. $B$, Typical adult. $C$, Gerontic individual. $A, B$, From Monongahela Formation, Scott's Cut, Warnock, Ohio (FMNH). $C$, From "Lower Washington Limestone Member," Washington Formation, Ayers limestone quarry, Belmont County, Ohio (USGS 24855-PC).

6), the form of the barrier microprojections remains relatively unworn and is suitable for study after very careful cleaning.

As is discussed later in this report, the data presented above (p. 62-73) are sufficient to classify Anthracopupa ohioensis with the Tornatellinidae; to define the subfamily Anthracopupinae Wenz, 1938; and to include several less well known taxa in the genus Anthracopupa.

\section{Subfamily ANTHRACOPUPINAE Wenz, 1938}

Description.-Parietal and columellar barriers typical of family, lip thickening internally and developing two ridges only in late growth stages. Apex smooth, postapical sculpture of low to strong radial ribs.

Discussion.-Because of the unusual pattern to formation of the shell lip, the great time gap between Anthracopupa and the modern Tornatellinidae, and the high degree of subfamily and tribal divergence among the modern taxa (Cooke and Kondo, 1960, p. $16-18,50,51$ ), we accept subfamily-level divergence for the Anthracopupinae.

Only one genus, Anthracopupa Whitfield, 1881, is recognized and Maturipupa Pilsbry, 1926, is listed as a subjective synonym.

\section{Genus Anthracopupa Whitfield, 1881}

Anthracopupa Whitfield, 1881, p. 126. Type species: Anthracopupa ohioensis Whitfield, 1881; original designation.

Maturipupa Pilsbry, 1926, p. 317. Type species: Pupa vermilionensis Bradley, 1872; original designation.

Pilsbry (1926, p. 317) separated Maturipupa from Anthracopupa as it was originally illustrated on the basis of Maturipupa's much more elongated shell, oblique parietal margin, and shortly ovate aperture. Because these differences represent the extremes of the shape and ontogenetic variation within a species as discussed above, Maturipupa is here placed in subjective synonymy. The comment of Pilsbry (1926, p. 317) that the shell "*** has more resemblance to the Tornatellinidae or to some Auriculidae (=Ellobiidae) than to any Pupillidae, and it probably does not belong to the latter family" was not accepted by subsequent workers. Henderson $(1935$, p. 150, 151) and Yen (1949, p. 236) continued to place Maturipupa in the Pupillidae; Wenz (1938, p. 52, 68) and Zilch (19591960, p. 63,64) grouped the two taxa as a subfamily of the Ellobiidae; Knight, Batten, and Yochelson (1960, p. I318) placed them in the prosobranch group Cyclophoridae.

The question of potential family affinities for Anthracopupa is obviously controversial. On the basis of the structural features described above, we make the following arguments. Reference to the Cyclophoridae, or any other prosobranch group, is improbable because Anthracopupa has both a parietal and a columellar barrier. As noted under the discussion of Dendrofupa, coexistence of major apertural barriers and an operculum (other than a remnant) is not possible. Barriers equivalent to those in the endodontid land snails are found in only one land prosobranch group, the helicinid subfamily Proserpininae. The barriers are particularly strongly developed in the genera Proserpina Gray, 1839, from Jamaica and Ceres Gray, 1856, from Mexico. Prosperinella Bland, 1865, and Cyane H. Adams, 1870, have reduced barriers. None of these genera have an operculum, and in their pattern of shell form and anatomical structure, they are clearly helicinid. Anthracopupa and all extant cyclophorid groups do not have features with detailed similarities. The presence of the two barriers throughout ontogeny in Anthracopupa led us to exclude prosobranch affinities from further consider- 
ation. We cannot exclude the slight possibility that Anthracopupa was a nonoperculated prosobranch, but because of the striking detailed similarities of Anthracopupa to extant pulmonate families, we consider that it was a pulmonate land snail.

The assignment of Anthracopupa by Wenz (1938) and Zilch (1959-1960) to the only terrestrial group of the superorder Basommatophora, the Ellobiidae, follows a suggestion by Pilsbry (1926); their assignment is based in part on errors in the original illustrations. Both Whitfield (1881) and Bradley (1872) showed the parietal margin as being weakly arched and obliquely angled to the shell axis. The typical pupillid-tornatellinid has a much more strongly arcuate and angled margin. Illustrations presented here (figs. 3-6) show that the parietal margin is well within the pupillidtornatellinid range, and that it is quite different from the ellobiid slanted parietal wall (see Zilch, 19591960, p. 64-78). A general difference also exists in the barrier position and structure. In the ellobiids, the parietal barrier, if single, invariably is located near the parietal-collumellar margin, and the columella is sinuately twisted and has a ridged barrier. In Anthracopupa (pl. 6, figs. 3-6), the parietal barrier is higher on the parietal wall, and the columellar barrier is lamellar and not sinuate.

The greatest similarity of Anthracopupa to the Ellobiidae is in the method of palatal lip thickening. In the Holocene Ellobiidae, such as Pythia Röding, 1798, Cassidula Ferussac, 1821, and Ellobium Röding, 1798, the palatal lip first reflects slightly, then builds up internally and narrows the aperture by inward growth, just as in Anthracopupa (fig. 5). We consider this similarity to be convergent in nature. The basic shell form of the Ellobiidae, even in Carychium Müller, 1774 (see Pilsbry, 1948, p. 1051-1061), retains the oblique parietal wall and rarely adopts a pupilliform or tornatelliniform shape. Moreover, the shell structures of the Ellobiidae and of the higher pulmonates are fundamentally different. In the Ellobiidae, the shell axis and whorl partitions in the upper spire are resorbed by the animal; they are not resorbed in the pupillid-tornatellinid lineages. The elegant study on Pythia by Harry (1951, figs. 9-10) and the illustrations of Carychium in Pilsbry (1948, figs. 562A, 566A, 567B) show quite well that resorption has taken place. Anthracopupa (fig. 3) retains the upper whorl partitions, and thus it cannot be grouped with the Ellobiidae. The lip formations of Anthracopupa and the Ellobiidae are similar only very late in ontogeny. The differences in parietal barrier positon, parietal wall angle, upper whorl partitions, and basic shape are ontogenetically earlier and combine to separate the two groups clearly.
The problem then becomes to compare Anthracopupa with extant groups of the superorder Stylommatophora. The shells of groups such as the Enidae, Subulinidae, Urocoptidae, Achatinidae, and Bulimulidae, with which Dendropupa was compared, are much larger, have more whorls, and have quite different growth patterns than shells of Anthracopupa. The zonitidendodontid-helicoid taxa differ in sculpture, form, whorl count, and many other features. We consider that small size, presence of apertural barriers, and relatively few whorls, very narrow columella (fig. 3 ), elongated shell form, and simple shell sculpture, narrow the choice down to the pupilloid-tornatellinoid lineages. Both of these groups traditionally have been cited as potential relatives of Anthracopupa. We must first indicate whether constant shell differences exist between the pupilloids and tornatellinoids, and then indicate to which pattern Anthracopupa conforms.

The growth pattern shown by the apex and spire is a major and characteristic difference between pupilloid and tornatellinoid taxa. In the pupilloid groups (fig. $6 A$ ), the upper spire has a distinctly convex outline resulting from significant decoiling. In contrast, the typical tornatellinoid form (fig. $6 B$ ) results in a nearly straight-sided spire outline, or at most (fig. $6 C$ ), a very slight convexity. These differences hold for almost all taxa but are subject to certain growth modifications that are easily recognizable as exceptions. To test the significance and stability of this difference, all species of pupillids illustrated in the comprehensive monograph by Pilsbry (1916-1935) and all the tornatellinids illustrated by Pilsbry and Cooke (1914-1916), Odhner (1922), and Cooke and Kondo (1960) were scored by Barbara Walden as to whether the spire outline was pupilloid, tornatellinoid, or intermediate. Not all named species are illustrated in these papers, and no attempt was made to cover pupillids described since 1935. Only a few proved difficult to assign to a category, as can be seen from the results summarized below:

Number of taxa having basic spire form (percentages in parentheses):

$\begin{array}{lcrr} & \text { Pupilloid } & \text { Intermediate } & \begin{array}{c}\text { Tornatel. } \\ \text { linoid }\end{array} \\ \text { Pupillids (all) } & & & 145(27) \\ \text { Pupillids (normal) }-- & 339(62) & 63(11) \\ \text { Tornatellinids }--- & 252(86) & 31(11) & 8(3) \\ & 0 & 3(1) & 227(99)\end{array}$

Two species of tornatellinids having an intermediate spire shape have a very blunt apex and expanded early spire. They are Tornatellides oncospira Pilsbry and Cooke, 1915 (Pilsbry and Cooke, 1914-1916, p. 214, pl. 46, fig. 8), and T. oswaldi Cooke and Kondo (1960, p. 257, fig. 109a). The third species, Fernandezia cylin- 

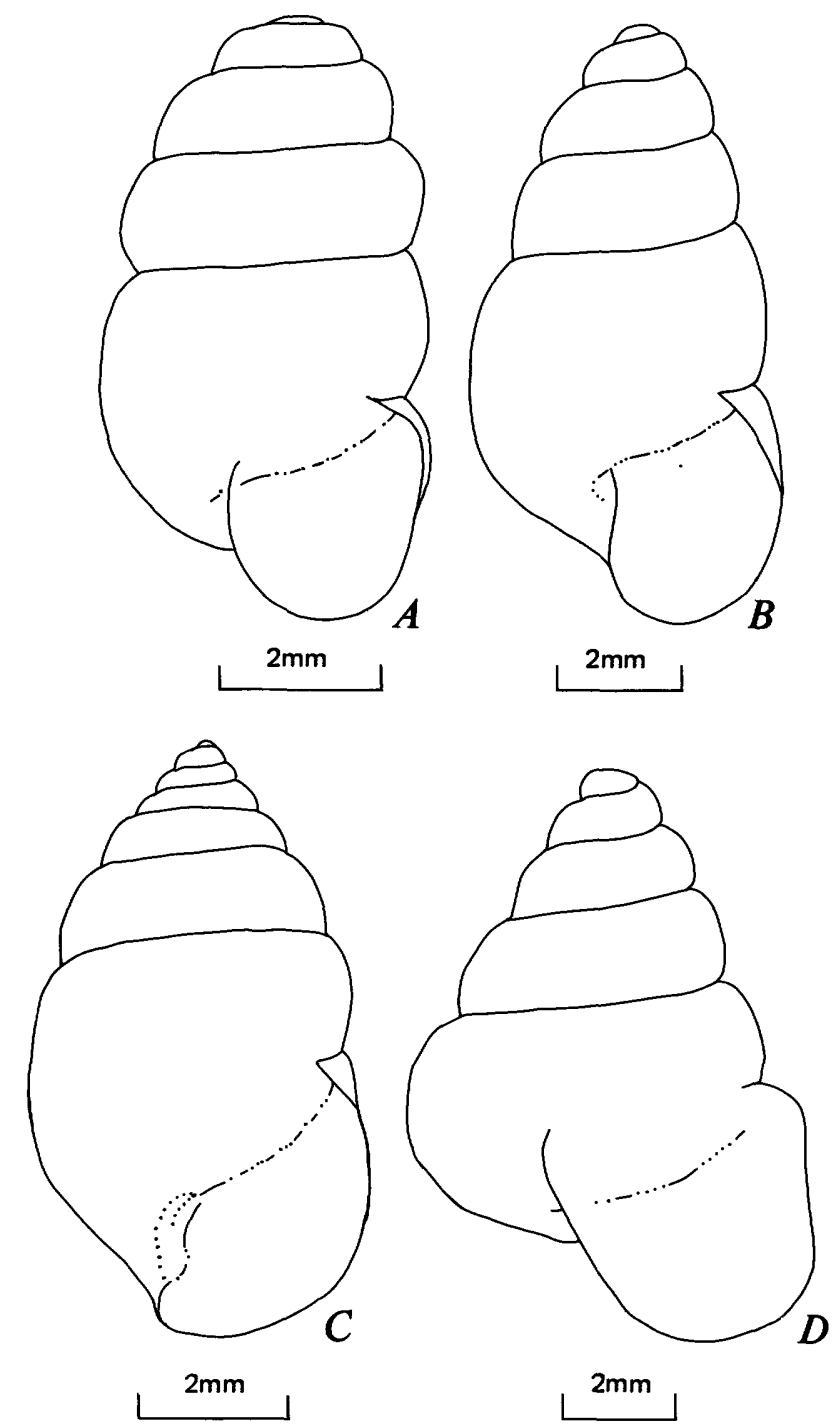

Figure 6.-Shell-form differences in the pupillid $(A, D)$ and tornatellinid $(B, C)$ taxa. Apertural barriers omitted from all these figures. A, Vertigo modesta (Say, 1824) modified from Pilsbry (1948, p. 983, fig. 527); B, Lamellidea (L.) oblonga (Pease, 1864) modified from Cooke and Kondo (1960, p. 203, fig. 89e); C, Antonella trochlearis fusiforma Cooke and Kondo, 1960 (modified from Cooke and Kondo, 1960, p. 121, fig. 54c); D, Bensonella lamothei (Bavay and Dautzenberg, 1912) modified from Pilsbry (1916-18, pl. 35, fig. 3).

drella Odhner (1922, p. 242, pl. 9, fig. 49), has a subuliniform shape and a greatly increased whorl count. It is very atypical of its genus, which is composed mostly of bulimuliform species.

The pupilloid taxa having tornatelliniform spire shapes have achieved this shape either by whorl-count increase with shell elongation or by becoming squatly triangular in outline (fig. $6 \mathrm{D}$ ). Comparatively few of the 50 full pupillid genera are involved in these alterations. A summary of the spire-outline distribution in the elongated taxa follows:
Number of species having basic spire form (dash leaders indicate none found):

\begin{tabular}{|c|c|c|c|}
\hline & Pupilloid & $\begin{array}{l}\text { Inter- } \\
\text { mediate }\end{array}$ & $\begin{array}{l}\text { Tornatel } \\
\text { linoid }\end{array}$ \\
\hline Fauxulus Schaufuss, 1869 & 4 & 2 & 4 \\
\hline Abida Leach, 1830 & 5 & 10 & 4 \\
\hline Granopupa O. Boettger, 1889 & 2 & 7 & 3 \\
\hline Chondrina Reichenback, 1828 & 3 & 16 & 7 \\
\hline Lauria Gray, 1840 & 37 & 15 & -- \\
\hline Pupoides L. Pfeiffer, 1854 & 4 & 19 & 2 \\
\hline Pupisoma Stoliczka, 1870 & -- & 22 & -- \\
\hline Nesopupa Pilsbry, 1900 & 32 & 23 & -- \\
\hline Totals & 87 & 114 & 20 \\
\hline
\end{tabular}

An additional 35 of the tornatelliniform pupillid species are found in the squatly triangular genera $G i b$ bulina Beck, 1837, Hypselostoma Benson, 1856, Boysidia Ancey, 1881, Gyliotrachela Tomlin, 1930, Systenostoma Bavay and Dautzenberg, 1909, Anauchen Pilsbry, 1917, Aulacospira Moellendorff, 1890, and Odontocyclas Schlüter, 1838. Such recently described or separated genera as Ulpia Scott, 1955, Afriboysidia Zilch, 1939, and Bensonella Pilsbry and Vanatta, 1900, have the same growth form. The shells are essentially triangular in outline and have the whorls decoiling regularly down to, and often strikingly on, the body whorl (fig. 6D). In these taxa, the whorl count is low, the altered decoiling pattern has produced convergence in the spire shape.

Thus, 55 of 63 "tornatelliniform" pupillid species are in genera that have greatly altered whorl counts or atypical decoiling patterns, and 114 of the 143 pupillids having intermediate shapes are in the few elongated genera that have higher whorl counts. If the "typical" or "normal" pupillids are compared with the tornatellinids, then the differences in shape are striking and highly stable.

In whorl count and basic shell shape, Anthracopupa is very similar to typical pupillids and tornatellinids, but in spire shape (pl. 5, fig. 1; pl. 6, figs. 1, 3, 5; pl. 8, figs. 3, 4; figs. 3, 4), Anthracopupa has the characteristic appearance of the Tornatellinidae.

In yet another fundamental feature, the pupillids and the tornatellinids differ without overlap. Tornatellinids, except Achatinella and its Hawaiian relatives, have a few too many apertural barriers present in juveniles. These barriers continue in many taxa until or even through the gerontic growth stage. Fully adult specimens may have the barriers reduced or absent, but their presence in juveniles is characteristic of the family. In contrast, the pupillids only develop the apertural barriers when nearly adult or as part of the lip-formation syndrome that signals the end of shell growth. Although many pupillids are without these barriers and have only a reflected lip, the barriers themselves are never present in juvenile shells. Young Anthracopupa (pl. 6, figs. 3-6) have a well-developed 
columellar barrier and a parietal barrier, both of which continue into the adult growth stage (pl. 5, figs. 1,2 ; figs. 4,5 ), so that the tornatellinid barrier growth pattern is followed. The formation of a reflected lip in Anthracopupa is comparable with the lip formation in Auriculella Pfeiffer, 1855, and in a few Achatinella Swainson, 1828; lip expansion is a somewhat unusual feature in the Tornatellinidae.

Both tornatellinids and pupillids have microprojections on the barriers (Solem, 1972; Solem and Lebryk, 1976), but whether or not there are family-level differences in structures of these microprojections cannot be determined at this time.

To summarize the above discussion, shell shape, ontogeny of the barriers, and retention of internal early whorl sides by Anthracopupa clearly indicate that it is not closely related to the Ellobiidae and pupillid taxa. The features of Anthracopupa and the Tornatellinidae are compatible; only the unusual lip formation and palatal ridges of Anthracopupa depart from the standard tornatellinid pattern. Even the variation in shell shape seen in Anthracopupa ohoiensis (figs. 4, 5) finds a modern counterpart; species such as Lamellidea pusilla (Gould, 1847) see Cooke and Kondo, 1960, fig. 82a-p) and Tornatellides oblongus (Anton, 1839) (see Cooke and Kondo, 1960, fig. 105a-1) showing intra- and intercolony variations in shell shape and whorl shape.

In addition to Anthracopupa ohioensis, undescribed species of the genus are from near Prague and Vienna; A. britannica Cox, 1926, and A. rothenburgensis Hintze, 1933, are from Europe; and three taxa are from the Eastern United States-?A. parva (Stauffer and Schroyer, 1920), A. sturgeoni Solem and Yochelson, n. sp., and A. vermilionensis (Bradley, 1872). These species differ in details of shape, barrier development, size, and lip expansion. No key to identification of species is given because we lack sufficient information on the European taxa to permit assessment of their affinities. Comparative comments are included under the respective species.

\section{Anthracopupa sturgeoni Solem and Yochelson, new species Plate 9, figures 1-5)}

Diagnosis.-Shell small, slender, heavily ribbed. Parietal barrier thick and has a bulbous tip, columellar barrier deeply recessed and reduced in size, lip ridges as in $A$. ohioensis. A. ohioensis less elongated, barriers less thickened and modified even on gerontic shells, ribbing distinctly weaker and lip normally less thickened.

Description.-Shell narrow, elongated, probably has $5^{3 / 4}$ to $61 / 2$ whorls, spire not expanded rapidly, last whorls not bulbous. Sculpture of apical whorls un- known, lower whorls have prominent, slightly protractive radial ribs, whose interstices are three to four times their width. Sutures deep, whorls flatly rounded laterally. Aperture ovate, no parietal callus, ribs extend into aperture without modification. Parietal barrier very wide, thickened, has clearly bulbous tip. Columellar barrier deeply recessed, reduced in height and widened. Basal ridge weakly bifurcated, present only in gerontic individuals. Palatal ridge somewhat recessed, higher, and slightly bulbous compared with basal ridge. Height of shell an estimated $4-4.5 \mathrm{~mm}$, diameter $1.31-1.41 \mathrm{~mm}$.

Holotype.-Little Captina Limestone Member, Monongahela Formation, at USGS locality, USGS 24836-PC (USNM 242,705).

Paratypes.-USGS locality 24836-PC, 1 specimen (USNM 242,706); USGS locality 24840-PC, 3 specimens (USNM 242,707; 242,708; and 242,709); USGS locality 24851-PC, 4 speciments (USNM 242,710; 242,$711 ; 242,712$; and 242,713); USGS locality 24854PC, 1 specimen (USNM 242,714).

Discussion.-All known examples are from the Little Captina Limestone Member of the Monongahela Formation, except the specimens from USGS 24851PC, which are from the overlying "Uniontown Limestone Member," Uniontown Formation. No complete, undamaged specimens are known. The holotype is the nearest to being complete, but it is crushed laterally and has the upper spire broken off and twisted to one side. Nevertheless, this specimen permits grouping as one species the few spire and body whorl fragments that constitute the remaining material. Four apical fragments lack all sculpture (USNM 242,710$242,713)$, a small midspire fragment has well-preserved sculpture (USNM 242,714), an upper spire has good scuplture except on the apex itself (pl. 9, fig. 4, USNM 242,706), and three adult body whorl fragments (USNM 242,707-242,709) vary in sculpture and in age. In one body whorl fragment without sculpture, the lip is only slightly expanded and lacks the ridges, the parietal barrier is thinner and without the bulbous tip, and the columellar barrier reaches to the lip edge. A second specimen from the same locality also is without sculpture, but the lip is slightly thicker and has bare traces of the ridges, and the barriers are somewhat thicker. The third specimen also is barely adult, and sculpture has been worn off the shell.

The apex and spire (pl. 9, fig. 4) are narrow and have flatly rounded whorls and rather deep sutures. $A$. sturgeoni has very slight decoiling, and its prominent ribbing contrasts with that of $A$. ohioensis. The ribs in $A$. sturgeoni are narrow, high, and rather widely spaced (pl. 9, fig. 5) compared with those of $A$. ohioensis (pl. 9, fig. 6). The ribs of $A$. sturgeoni are more like 
those found in Dendropupa vetusta (pl. 4, figs. 2-4).

The aperture of $A$. sturgeoni is remarkable primarily for the bulbous termination of the parietal barrier (pl. 9, figs. 1-3), the deep recession and size reduction in the columellar barrier (which is barely visible from the angle shown on pl. 9, fig. 1), and the recession of the palatal ridge (pl. 9, fig. 2). The weakly bifurcated shape of the basal ridge shows well from the low-angle view shown on plate 9 , figure 3 . A comparison of figures 3 and 4 of plate 9 with the growth sequences shown in figures 4 and 5 indicates that lip thickening and growth patterns in the $A$. sturgeoni and in $A$. ohioensis are similar.

Despite the fragmentary and limited material available, the differences in shell ribbing and barriers are substantial enough to warrant naming $A$. sturgeoni a distinct species. The basic patterns of lip formation, barrier position, and ridge formation suggest that only specific-level differentiation from $A$. ohioensis is involved.

We consider it appropriate to name this species after Myron T. Sturgeon, who has worked in the Dunkard beds and has contributed materially to knowledge of the late Paleozoic gastropods of Ohio.

Anthracopupa parva (Stauffer and Schroyer, 1920)

Plate 1, figures 15-17, 20-22

Loxonema(?) parva Stauffer and Schroyer, 1920, p. 145, pl. 11, figs. 17-21.

We have examined the type specimens in the OSU Orton Museum, but because they lack some significant characteristics, we are uncertain as to the affinities of this species. All the specimens are juvenile, and only in the specimen we designate as the lectotype (pl. 1 , figs. 15, 20), can any part of the aperture be examined. We can detect no trace of any barriers on the parietal wall, and the columellar wall is partly broken and obscured, but has a trace of a barrier.

The sculpture of these specimens is quite similar to that of Anthracopupa sturgeoni (pl. 9, figs. 1-5) but is slightly finer. A. sturgeoni and ? A. parva differ most obviously in the spire angle; $A$. sturgeon $i$ has a narrower apical angle and a slightly wider body whorl. In contrast, the spire angle of all specimens of ?A. parva is greater, and the lower whorls are distinctly wider than in A. sturgeoni. Until we have adult specimens of ?A. parva, or at least juveniles having clear apertures so that the presence or absence of barriers can be checked, any generic assignment must be tentative. The spire angle of ? A. parva is intermediate between the wider angle of $A$. ohioensis and the very narrow angle of $A$. sturgeoni. The differences in these features are matched by the range of variation among species of extant tornatellinid genera. Tentative inclusion of Loxonema (?) parva in Anthracopupa is a conservative and appropriate treatment.

Anthracopupa sturgeoni is known only from the Little Captina Limestone Member of the Monongahala Formation and "Uniontown Limestone Member" of the Uniontown Formation, whereas ?A. parva is from the "Lower Washington Limestone Member" of the Washington Formation. No specimens referrable to ?A. parva were taken by Yochelson in his fieldwork on the Dunkard and Monongahela Groups.

Anthracopupa vermilionensis (Bradley, 1872)

Plate 1, figures 5-7

Pupa vermilionensis Bradley, 1872, p. 87, 88, fig. 1; Dawson, 1880 , p. 410 , 411, figs. 8, 9, 14c; White, 1883, p. 456, pl. 2, figs. 13, 14; Knight, 1941, p. 190, pl. 96, figs. 4a, b; Peck and McFarland, 1954 , p. 297, 306, pl. 29 , fig. 4.

Maturipupa vermilionensis (Bradley), Pilsbry, 1926, p. 317, pl. 32, figs. 17, 18; Henderson, 1935, p. 150, 151; Yen, 1949, p. 236; Zilch, 1959-1960, p. 64, fig. 203; Knight, Batten and Yochelson, 1960, p. I318, fig. 211; Yochelson and Saunders, 1967, p. 125.

The location of the type specimens is not known to us. Scattered material in collections dating from the late 1800's and early 1900's probably consist of specimens collected by Bradley, if not indeed actually representing cotype material. Included in this array are a miscellany of specimens-FMNH 51464 from the Walker Museum, FMNH 11675 from the Gurley collection, FMNH 4028 from the Illinois State Museum, and USNM 27611 received from F. H. Bradley in 1898. Size variation in the seven adults from the above sets is: height of shell, $3.09-3.72 \mathrm{~mm}$ (mean $3.35 \pm 0.087 \mathrm{~mm}$ ), diameter, $1.55-1.84 \mathrm{~mm}$ (mean $1.72 \pm 0.046 \mathrm{~mm})$, height/diameter ratio $1.84-2.14$ (mean $1.94 \pm 0.042$ ), whorls $47 / 8$ to $5 \frac{5}{8}$ (mean $5.08 \pm 0.114)$. The shells are thus slightly longer, are a little more slender, and have a very slightly higher whorl count than most of the measured Anthracopupa ohioensis (table 2). Although we maintain $A$. vermilionensis as a distinct species, collection of wellpreserved and more comprehensive materials might show that the populations fall within the range of $A$. ohioensis.

None of the specimens available to us had the palatal lip preserved, and most of the specimens had the aperture blocked by debris. Two partly cleaned specimens that had the palatal lip badly damaged or missing as a result of preparation showed the same parietal and columellar barriers as in A. ohioensis (pl. 1, fig. 5).

Some fragmentary specimens of $A$. vermilionensis are preserved in the Illinois State Geological Survey. Generally more specimens of Dawsonella than of $A$. vermilionensis are in these same samples, some of which contain many specimens of Spirorbis. A. 
ohioensis samples also contain many specimens of Spirorbis. None of the specimens loaned by Dr. Lois Kent had the apertures intact, and none add any new data to our understanding of the species. They do provide additional verified localities of occurrence:

Freshwater beds below Macoupin, Center $\mathrm{N} 1 / 2$, sec. 27, T. 7 N., R. 10 E., Jasper Co., Illinois. J. M. Weller.

St. David Formation, ${ }^{5}$ along Little Vermilion River, a short distance above Petty's Ford, SE $1 / 4$ NW $1 / 4$, sec. 2, T. 17N., R.11W., Vermilion Co., Illinois. J. M. Weller, 1928. No Spirorbis.

South bank of Hodges Creek, northwest of Chesterfield, SW $1 \frac{1}{4}$ sec. 30, T. 10 N., R. 9 W., Macoupin Co., Illinois. J. M. Weller, 1927.

West of coal mine in bluff on right bank, SW $1 \frac{1}{4}$, sec. 29, T. 17 N., R. 10 W., Vermilion Co., Indiana.

No count was attempted because of the multiple nature of the fragments and the thickness of the matrix. These records do confirm the joint occurrence of $A$. vermilionensis and Dawsonella, indicate that at least rarely they were found with Spirorbis, and provide potential sites for additional collecting activities.

Because of its shape, sculpture, and basic barrier structure, A. vermilionensis unquestionably belongs to the same genus as $A$. ohioensis, and it may well be conspecific with that species.

\section{Subfamily DAWSONELLINAE Wenz, 1938}

Description.-Typical neritoid shelf concave over umbilicus, spire normally elevated, few whorls without marked sculpture, lip weakly expanded and thickened.

\section{Genus Dawsonella Bradley, 1874}

Dawsonella Bradley, 1874, p. 151. Type species: Anomphalus meeki Bradley, 1872; original designation.

Description.-Shell small, with as many as $33 / 4$ rather rapidly widening whorls. Lip thickened and expanded, sharply angled at basal-columellar margin. Umbilicus covered in juveniles and adults by a concave callus that narrows the aperture. No prominent shell sculpture.

Discussion.-Dawson (1880, p. 413) compared Dawsonella with two polygyrid land snails, Stenotrema leai (Binney, 1841) and Triodopsis (Xolotrema) notata (Deshayes, 1830), but the barrierconstricted apertures of these shells, their strong surface sculpture, large number of whorls, reflected but thin adult lip, and large size $(7-25 \mathrm{~mm})$ easily distin-

\footnotetext{
s "St. David Limestone Member" of the Carbondale Formation, as currently used in Illinois nomenclature.
}

guish them from Dawsonella and make any relationship to Dawsonella highly improbable. Whitfield (1881, p. 127, figs. 5,6$)$ was the first to call attention to the similarities of Dawsonella to members of the family Helicinidae. The subsequent placement either in the Helicinidae or in a family unit, Dawsonellidae, standing next to the Helicinidae, is justifiable, but it is probably more conservative to treat the Paleozoic group as subordinate.

Dawsonella meeki (Bradley, 1872)

Plate 10, figures 1-6

Anomphalus meeki Bradley, 1872, p. 88, fig. 2.

Dawsonella meeki (Bradley), Bradley, 1874, p. 151; Dawson, 1880, p.413, figs. 12, 13; Whitfield, 1881, p.127, figs. 5, 6; Henderson, 1935, p. 159; Wenz, 1938, p. 52, 62, 434, 435, fig. 1070; Knight, 1941 , p. 97,98, pl. 96, figs. la-c; Yen, 1949, p. 236, 238; Peck and McFarland, 1954, p. 304, pl. 29, figs. 5,6; Knight, Batten, and Yochelson, 1960, p. I279, fig. 189.3; Yochelson and Saunders, 1967, p. 64; Solem, 1974, p. 175, fig. 3.

The location of the holotype is unknown. Six undistorted adult shells in FMNH 11673 from the Gurley Collection measured: height of shell, $2.30-2.89 \mathrm{~mm}$ (mean $2.66 \mathrm{~mm}$ ), diameter, 3.78-4.11 mm (mean 3.99 $\mathrm{mm}$ ), height/diameter ratio, 0.565-0.710 (mean 0.664 ), whorls, $3 \frac{1 / 4}{4}$ to $3 \frac{5}{8}$. They conform well to the material figured by Knight (1941) and Peck and McFarland (1954). Fragments in the Illinois State Geological Survey field collections made by J. M. Weller and listed under Anthracopupa vermilionensis were all subadult.

The most characteristic feature of the shell is a slightly concave plate (pl. 10, figs. 1,2$)$ that extends across the umbilical region. This plate is present in juveniles as well as adults, has an abrupt apertural margin, and effectively narrows the aperture. This plate is the typical neritacean shelf and, despite the lack of direct evidence, we assume it was accompanied by a neritoid operculum. Few dead helicinids that are found today in stream drift have the operculum in place, and indeed, few helicinid opercula have been found in drift deposits. The flat pebble shape of the operculum does not lend itself to accidental transport, whereas the globular shell can entrap a bubble of air and thus be transported for a considerable distance by a brief flood following a heavy rain. The absence of opercula in these deposits is not surprising to us.

The shell lip is slightly reflected (pl. 10, figs. 1,2 ), is only moderately thickened internally (pl. 10, fig. 1), and has a fairly heavy parietal callus (pl. 10, fig. 2). One highly significant feature relating to classification of this species is found at the basal-columellar margin (upper right of figs. 1, 2, of pl. 10) where the lip is sharply angled and protrudes in a right-angled turn. 
This protruded corner of the aperture is a characteristic of such modern helicinids as Pseudhelicina Sykes, 1907, Waldemaria A. J. Wagner, 1907, Oligyra Say, 1818, Alcadia Gray, 1840, Pleuropoma Moellendorff, 1893, and Schasicheila Shuttleworth, 1852. The heavy umbilical callus is a general feature of the Helicinidae, as is the low whorl count.

Surface sculpture of the shell (pl. 10, fig. 3) is undistinguished, showing no major features that would be indicative of a particular group. The shell structure itself (pl. 10, figs. 4-6) has a rather complex pattern of shell layers but the complex layers probably are a replacement phenomenon rather than the original structure.

Fragmentary specimens having shattered whorls show that the shell was quite thick and solid, another feature agreeing with the pattern seen in such drier zone helicinid species as Oligyra orbiculata tropica (Pfeiffer, 1852) and the Pacific Islands Orobophana Wagner, 1905, complex.

Because the shell of Dawsonella meeki is relatively simple in structure, it has few positive features to suggest family-level affinities. The umbilical callus, neritoid shelf, protruding basal-columellar lip junction, and thickening of the lip internally are all fully consistent with the extant Helicinidae. The basic shell shape, possession of only a few whorls, size, and lack of positive shell sculpture also are consistent with the Helicinidae. We can find no characters to separate Dawsonella from the Helicinidae.

Because of the concave umbilical callus surface and the large time gap, we accept the Dawsonellinae Wenz, 1938, as a subfamily unit of the Helicinidae.

\section{OTHER PALEOZOIC NONMARINE SNAILS}

We cannot offer a detailed review of Paleozoic nonmarine snails from other parts of the world. We do provide comments and suggestions for study, on the basis of a survey of the literature and examination of some materials. We try to place both the land and freshwater taxa within the systematic framework and the time scale worked out for the North American land taxa. Comments given by Yochelson $(1975, \mathrm{p}$. 254-256) concerning the placement of some of these species were preliminary and, in the main, were based on a misunderstanding of the genera.

A fair record exists of one species of land snail from England. Anthracopupa britannica Cox (1926, p. 407-410, figs. 1,2) was described from the Keele beds (Westphalian D) near Hagley Park, Birmingham, England. The species was reassigned to Maturipupa by Yen (1949), but this reassignment has been ignored by later British workers. The outline drawings of the original material show a well-developed parietal barrier and suggest a low, rather recessed columellar barrier equivalent to that described for Anthracopupa sturgeoni. In size and shape, $A$. brittanica is similar to A. ohioensis, but differs in possessing a lower, apparently deeply recessed, columellar barrier.

Poole (1969) summarized occurrences to date of the species in boreholes and indicated a local stratigraphic range of more than 350 feet $(107 \mathrm{~m})$. Calver (1969), in a definitive summary of the Westphalian of Britain, reported $A$. britannica from several localities in the Pennines and Midlands. At one locality, Uptown borehole, Oxfordshire, it ranges through about 1,800 feet $(549 \mathrm{~m})$ of strata. Calver dated the beds then known to contain the species as probably late Westphalian D, but he could not rule out an early Stephanian age. Subsequently, both the geographic and geologic ranges have been extended significantly. Calver (in Richardson and Francis, 1971, p. 238, pl. 22, figs. 1-4) reported finding this species at half a dozen localities in the north of England and in southern Scotland, where he identified it in beds of Westphalian A age. His data included a few measurements and photographs of the species.

The single French record of a Paleozoic land snail is the specimen named Dendropupa walchiarum Fischer $(1885$, p. 100$)$ from the "Permien moyen de Chambois (Saône-et-Loire)." This report describes a partial individual, estimated to have been $12 \mathrm{~mm}$ high and $4 \mathrm{~mm}$ in diameter when complete. All published information on shape, size, sculpture, and aperture are consistent with the structures reported above for Dendropupa vetusta. We have not been able to locate the holotype. It is not in the collection of the Journal de Conchyliologie, the Museum National d'Histoire Naturel, Paris, which holds many of the types of species described in that publication, nor in the Ecole de Mines. Without restudy of this unique fossil, we cannot comment further on its possible affinities. Pruvost $(1957$, p. 19) notes that Saône-et-Loire is in the Autun Basin. A geologic map (Feys and Greber, 1964, p. 49) shows Chambois to be near the north edge of the basin, north-northwest of Autun. It is in an area mapped as lower Autunian, in the Lower Permian. The record is thus much younger than that of Dendropupa vetusta, which is known from the lower upper Carboniferous. Whether this species is specifically or generically separable from Dendropupa is unknown.

The German Anthracopupa rothenburgensis Hintze (1933) from the Mansfelder Schichten of Halle, West Germany, is only slightly better known; the material is late late Carboniferous (early Stephanian) in age (H. Jaeger, written commun., 1971). As indicated by the published sketches, this is a slender, 
rather small species that has three barriers in the aperture. The published data do not indicate whether the lip was thickened, and $A$. rothenburgensis may well prove to belong to a distinct genus. The age of $A$. rothenburgensis fits in well with the record of other species of Anthracopupa; $A$. rothenburgensis is intermediate between the age of $A$. ohioensis and that of $A$. vermilionensis. A small helicoid snail from the same deposit was not named. It is only $2.2 \mathrm{~mm}$ in maximum dimension and has a deep and widely open umbilicus. We can offer no suggestions as to its affinities.

Staesche $(1963,1969)$ discussed the fauna of the East German Lower Permian Rotliegende. Several forms had been called gastropods, but we agree with Dawson $(1880)$ and Staesche $(1963,1969)$ that none of this material can be considered of gastropod origin. Probably all are worm tubes, closely related to or identical with Spirorbis.

A potentially diverse fauna of land snails has been collected from the Lower Permian beds near Karniowice, $35 \mathrm{~km}$ west of Krakow, Poland. Dendropupa zarecznyi Panow (1936, p. 37-41, pl. 1, figs. 1-6) consists of two species. The larger (Panow, 1936, pl. 1, figs. 1,2 ) is a Dendropupa related to $D$. vetusta. Additional specimens from the type locality were collected in 1968 by E. L. Yochelson, S. Gasioroski, and A. Gromczakiewicz. Some years ago, specimens from Panow's collection were donated to the USNM. One steinkern in the USNM collection shows the same open umbilical region found in $D$. vetusta. On another specimen, fragments of axial sculpture are preserved. We have no doubt that these specimens are Dendropupa. Obvious differences from $D$. vetusta include a lower whorl count (less than seven), apparently wider whorls, and finer sculpture. We can offer no opinion as to the relationships among Dendropupa vetusta, $D$. walchiarum, and D. zarecznyi.

The smaller, narrower species (Panow, 1936, pl. 1, figs. 3-6) is less abundantly represented in the material available to us, and the specimens are slightly to moderately distorted. No traces of any sculpture remain, and we can only comment that in shape and form the specimens resemble Dendropupa primaeva (Matthew, 1895).

Yochelson collected his material in the lower part of the Karnovice Limestone, which is about $6 \mathrm{~m}$ in maximum thickness and is exposed near a hillcrest. The few specimens were associated with large fragments of stems and leaves. Examination of the outcrop showed that the lower part of this unit contains abundant broken plants and leaves. The upper part has two lithologies that are repeated several times. One of these is an "organ pipe" limestone, apparently formed by lime deposited around the stems of reedlike plants, which are now elongate holes in the rock. Alternating with this is a fine-grained limestone, locally having some holes, which is suggestive of deposition by an algal mat. Although the Karnovice beds are conventionally referred to as a travertine, they might equally well be interpreted as a lime-rich shallow pond.

The late Dr. Jon Weber, of Pennsylvania State University, kindly analyzed the isotopic composition of all three limestones. Data are reported in relation to the PDB standard in standard $\sigma$, notation as:

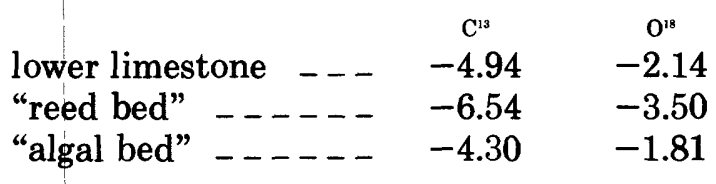

He reported that these values are typical of freshwater carbonate rocks. With other evidence, they could be used to support a conclusion in favor of freshwater deposition for the Karnovice Limestone.

The age of this deposit has been redefined as early Autunian by Lipiarski (1971) in her revision of the Carboniferous and Permian plants of Poland. Lipiarski uses Autunian as nearly equivalent to the German Rotliegende, the uppermost part of the unit being Saxonian.

During 1975, Yochelson was shown two European Lower Permian assemblages of land snails that have not yet been reported in the literature. Near Ceský Brod, east of Prague, Czechoslovakia, several thin limestones in a red-shale sequence contain specimens of an Anthracopupa and possibly of other taxa. In the vicinity of Eggenberg, Austria, Anthracopupa occurs sparingly in similar rocks. These records will extend the geographic distribution of Anthracopupa, but we cannot comment on specific affinities at this time.

Records of Paleozoic nonmarine snails from the U.S.S.R. are equivocal. Cox (1953) directed attention to the report of Revunova (1938) on Tartarian Age snails from the Sukhona-Mezen Rivers area, in the Vologda region north-northwest of Moscow. They were described as freshwater taxa, but the late Dr. Boris Licharev (written commun., 1971) reported that "It is necessary for me to tell you that the species in my possession was described by Revunova in 1938 as Omphaloptychia malachovi. The author of that article did not clean the aperture of his specimens and missed the presence of a tooth therein." Thus, at least some of this material may represent land-snail species, but without restudy, no additional comments can be made.

These are the only certain records of Old World Paleozoic land snails or possible land-snail fossils that we have been able to locate. They extend the geographic ranges of Anthracopupa and Dendropupa from 
North America to Europe and also increase the known time range of Dendropupa into the Early Permian.

Several records of Paleozoic freshwater gastropods exist and are summarized below, although we can offer no meaningful comments on the affinities of the taxa. They do establish that the freshwaters had been colonized successfully by a variety of taxa in the late Paleozoic.

The earliest record is from Devonian beds near D’Aiguillon, Gaspé Peninsula, Quebec, Canada (Russell, 1947, p. 4). "A small gastropod, of generalized, viviparid-like form, was obtained" together with a clam similar to Modiomorpha, eurypterids, and fish remains. To our knowledge, this gastropod has not been described.

The species Carbonispira scotica Yen (1949) is represented by a single flattened, partly destroyed specimen. Although the specimen is dubiously describable and in poor condition, the suggestion by Yen that this may be a thiarid prosobranch is the best that can be made at present. The single specimen of Carbonispira was collected from shales below the Top Hosie Limestone of Namurian A, early late Carboniferous age (George and Black, 1971, p. 199).

Bernicia praecursor Cox (1927) was compared to the amnicolid hybrobiids, a conclusion with which we do not disagree. It is from rocks of the Scremerston Coal Group, of late Early Carboniferous (Viséan $\mathrm{D}_{2}$ ) age (George and Black, 1971, p. 335), from near Scremerston, Northumberland, England.

Hydrobia gondwanica Cox (1953) from the Upper Permian Karroo Beds of Southern Rhodesia is an elongated hydrobiid shell and shows few unusual shell features. The existence of the European modern genus Hydrobia in the Permian is improbable, but proposal of a new generic name is unwise without added information on the shell structure. Subsequently, Rossouw (1970) reported, but neither described nor illustrated, a large $(34 \mathrm{~mm})$ freshwater snail from the Lower Beaufort beds at Weltevrede, South Africa, and an obscure early record of a planorbiform snail in the upper Paleozoic of Madagascar. The latter could be based on worm tubes.

Runnegar and Newell (1971, p. 25, 26, 54, figs. 24AC) have provided one record from the Lower Permian in the Estrada Nova Formation in the Paraná basin of Brazil. Yochelson was quoted as referring these to Dendropupa, an error in judgment made at a time when Dendropupa was poorly understood. Restudy of these casts, from USGS locality 22836-PC, suggests that the material represents at least two, if not more, species of freshwater "hydrobiid" snails. The elongated morph that was figured by Runnegar and Newell (1971, figs. 24A-C) has an angled periphery, and, in the better preserved large individuals, a truncated columella. This pattern is exactly equivalent to the modern hydrobiid Lyrodes Doering, 1884, in its nonspinate stage, and to the Old World genus Potamopyrgus Stimpson, 1865. The apparent columellar barrier mentioned by Runnegar and Newell (1971, p. 26 , fig. 24A) appears to be based on a fleck of dirt that was accentuated in retouching. The short, broader morph is roughly equivalent to such modern Neotropical hydrobiids as Aroapyrgus alleei Morrison (1946, pl. 2, fig. 4). In his review of the Tertiary nonmarine mollusks of South America, Parodiz (1969, p. 117,118) reported Lyrodes from the Oligocene of Colombia. Other taxa are Miocene and Pliocene, so that early Tertiary and Mesozoic records are lacking.

The fragmentary record of late Paleozoic freshwater snails includes apparent hydrobiids from England, Rhodesia, and Brazil; a possible thiarid from England; a "viviparid-like form" from Canada; and unclassifiable materials from South Africa and Madagascar. No freshwater pulmonate taxa have been recorded, despite the extensive freshwater bivalve fauna from many areas of the world. The data are insufficient to permit any sweeping conclusions. We can say that the record to date shows that freshwater gastropods preceded terrestrial ones by some millions of years. Paleozoic freshwater taxa occur both in Europe and in areas that formerly constituted Gondwanaland and they are found in older beds in the Northern Hemisphere. Terrestrial forms are known only from the Northern Hemisphere.

\section{SYSTEMATIC SUMMARY}

The classification of the Paleozoic land snails known from North America which has been discussed in the preceding pages is summarized in table 6 ; the ordinal and superfamily groupings are from the system proposed by Solem (1978), which in turn is modified froin the systems of H. A. Pilsbry and H. B. Baker.

The distribution of the 10 fossil species among 5 families and 3 orders of land snails emphasizes that a diverse fauna of land snails already existed before the end of the Paleozoic.

The confidence levels of family-group assignments for the studied material are summarized below. Solem judges that the evidence for family-level placement of Anthracopupa and Protodiscus is more than substantial. The complexity of the shell microstructural-ornament details in both fossil taxa and their extant relatives is such that convergent evolution is most improbable. We judge that these family assignments are quite firm. 
TABLE 6.-Systematic list of the Paleozoic land snails

Class Gastropoda

Subclass Prosobranchia

Order Diotocardia

Superfamily Neritacea

Family Helicinidae

Subfamily Dawsonellinae

Dawsonella meeki (Bradley, 1872)

Subclass Pulmonata

Superorder Stylommatophora

Order Orthurethra

Superfamily Achatinellacea

Family Tornatellinidae

Subfamily Anthracopupinae Wenz, 1938

Anthracopupa ohioensis Whitfield, 1881

?Anthracopupa parva

(Stauffer and Schroyer, 1920)

Anthracopupa sturgeoni So-

lem and Yochelson, n.sp.

Anthracopupa vermilionensis

(Bradley, 1872)

Superfamily Pupillacea

"Pupa" bigsbii Dawson, 1880

Superfamily Partulacea

Family Enidae

Subfamily Dendropupinae Wenz, 1938

Dendropupa vetusta (Dawson, 1867)

?Dendropupa grandaeva

(Dawson, 1880)

Dendropupa primaeva

(Matthew, 1895)

Order Sigmurethra

Suborder Aulacopoda

Superfamily Arionacea

Family Discidae

Protodiscus priscus (Carpenter, 1867)

The evidence concerning Dawsonella and Dendropupa is at a somewhat lower confidence level. The shell structure of Dawsonella is relatively simple. All of its few unusual features agree with the structures found in the extant Helincinidae. These structures are not unique among extant gastropods, although the particular combination of structures seen in Dawsonella is not duplicated in any other family. We cannot rule out the possibility that Dawsonella is convergent to the Helicinidae, but because no structures of Dawsonella are incompatible with its assignment to the helicinids, we are convinced that this family assignment is reasonable. Dendropupa shows most similarity to the Enidae and has been placed in that family. The genus could be a prototype for the Urocoptidae, but Solem considers that this is unlikely, as basic shell-growth features in Dendropupa and the Urocoptidae are inconsistant. Dendropupa may belong to an extinct family unit that was ancestral to the enid lineage, but the preponderance of evidence supports our including it as a subfamily of the Enidae.

The assignment of "Pupa" bigsbii to the Pupillacea is based on only one character complex, the apex and spire growth pattern. This pattern effectively separates this species from the Tornatellinidae, but assignment to any family unit of the Pupillacea is precarious.

\section{PHYLETIC SIGNIFICANCE}

The occurrence of five families and three orders of land snails in the Pennsylvanian-Permian section of the fossil record has several interesting evolutionary implications. First, considerable taxonomic diversity is exhibited by the oldest known land snails. Indeed, half the gastropod orders that have produced land snails were present when this group initially appeared in the fossil record. Second, all the five family-level groups found in the Paleozoic are still extant. This fact indicates a basic conservatism among the higher land-snail taxa. Third, the time and sequence of appearance of the gastropod orders have considerable bearing on evolutionary direction and speculations as to interordinal relationships.

The oldest known Archaeogastropoda appeared in the Late Cambrian. Yochelson (unpub. data, 1977) judges that all the assignments of Early and Middle Cambrian fossils to the Class Gastropoda that are recorded in the literature are spurious. The superfamily Neritacea is recorded first from the Middle Devonian of Great Britian, about 375 million years ago. By the Early Mississippian, neritaceans were widely spread in marine deposits. Thus, presence of a terrestrial neritacean, Dawsonella, by the late Middle Pennsylvanian indicates that less than $75,000,000$ years passed between the origin of the neritaceans and their recorded presence on land. Discovery of terrestrial neritaceans in earlier deposits would not be surprising. The earliest record of a freshwater neritacean, however, is not until the very end of the Jurassic (Mesoneritina Yen, 1946, from the Morrison Formation of western North America).

The presence of two orders and four families of the superorder Stylommatophora in the late Paleozoic is somewhat surprising. Conventionally, the superorder Basommatophora has been assumed to be more primi- 
tive than and ancestral to the superorder Stylommatophora. However, the first terrestrial basommatophoran is the ellobiid genus Carychium Müller, 1774, which appeared in the Late Jurassic of Europe; the first freshwater ellobiids are from the uppermost part of the Upper Jurassic Morrison Formation (Tortacella White, 1895, Zaptychius Walcott, 1883, Mesochilina Yen, 1951, Mesauriculstra Yen, 1952); the first marine ellobiids seem to be from the Upper Jurassic of Europe; and the first appearance of the higher limnic Basommatophora is in the same Morrison Formation (Lymnaeidae, Planorbidae, Physidae).

Thus, the superorder Basommatophora appeared about 150 million years later than the Stylommatophora. Perhaps the Basommatophora was derived from the Stylommatophora, the opposite of current thinking, or perhaps each had an independent origin from more primitive stocks.

In our opinion, the reality of this time gap cannot be seriously questioned. Even though the time of first appearance in the fossil record and the time of origin are not the same, the first records of both superorders indicate that equivalent degrees of diversity had been reached. Thus, pushing back the origin of the Basommatophora, could entail a similar backwards shift of the origin of the Stylommatophora. If the freshwater mollusk record were essentially unknown before the Late Jurassic, the absence of Basommatophora might not be considered highly significant. However, a scattered, but significant, record of early freshwater mollusks does exist. The Paleozoic viviparid-form, hydrobiid-form, and thiarid-like records were noted above. The Valvatidae and the Viviparidae are known from the Triassic, along with a very extensive record of freshwater clams. The earliest non-marine bivalve group seems to be the Late Devonian family Archanodontidae Weir, 1969, from the United Kingdom and North America, based on Archanodon Howse, 1878 (=Amnigenia Hall, 1885). By the early Carboniferous, a diverse group of "unionid precursors" existed, even though the Unionidae themselves did not appear until the Triassic. The late Carboniferous also saw the family Myalinidae make an incursion into fresh waters (data supplied by John Pojeta, Jr., 1975).

Thus, a significant record exists of several freshwater taxa older than the Late Jurassic. The number of records is such that, very probably, basommatophorans would have been preserved if they had been present.

The Morrison Formation (Yen and Reeside, 1946; Yen, 1952) is thus viewed as an indicator of the first flourish of the Basommatophora and the first extengive documentation of a rich freshwater mollusk. Be- sides the Physidae, Lymnaeidae, and Planorbidae, the Morrison contains representatives of the Neritinidae (Mesoneritina Yen, 1946), "Hydrobiidae," Viviparidae, Valvatidae (Amplovalvata Yen, 1952), several “Unio, s. 1.," Vetulonaia Branson, 1935, and the enigmatic clam genus Hadrodon Yen, 1952. Limopsis Yen, 1952 , was referred to the Otinidae, but we suggest that evidence is insufficient to refer this taxon to a family unit. The only unusual added element in this assemblage was the large number of freshwater Ellobiidae, because this taxon today inhabits mangrove and nipa palm swamps on the coast or brackish-water mudflat areas, and does not live in freshwater. Apparently the Ellobiidae underwent an extensive late Mesozoic freshwater radiation.

The presence of freshwater clams and prosobranches in Paleozoic deposits shows that the fresh water had been colonized by mollusks and that conditions favorable for their preservation existed long before the first recorded appearance of the Basommatophora. Thus, the absence of basommatophorans from the fossil record until the Jurassic-Cretaceous boundary suggests that they evolved later rather than that chance prevented their preservation. The earlier appearance, and thus probable much earlier evolution, of the superorder Stylommatophora indicates the need to reevaluate the relationship between these two superorders and the previously hypothesized direction of evolution leading from the $\mathrm{Ba}-$ sommatophora to the Stylommatophora.

We cannot resist speculating on one highly intriguing evolutionary correlation. The first appearance of the typical freshwater basommatophoran snails was at the end of the Jurassic in the Morrison Formation. Present in this fauna are the typical taxa of temporary ponds and streams, the families Physidae, Lymnaeidae, and Planorbidae. All these are capable of self-fertilization to start a new colony and frequently have been found on the feet and feathers of waterfowl; they are thus known to be dispersed by birds.

The coincidence of the sudden appearance of these freshwater snail taxa with the origin and radiation of birds cannot be ignored. As summarized by Cracraft (1973, p. 495, 496), the fabled Archaeopteryx appeared in the Late Jurassic, Australian and European records of waterfowl in the Early Cretaceous exist, and by the Late Cretaceous, a worldwide fauna of diverse waterfowl had evolved. Cracraft (1973, p. 496) concluded that "*** the Class Aves, much as we know it today, was present on all continents in the Cretaceous***" and that by the end of the Eocene "***approximately 26 of the 32 known orders are found as fossils." Thus, the sudden appearance of the hitchhiking basommatophoran pond snails may have been the 
result of pond-hopping birds in the Late Jurassic.

The essentially simultaneous recording of four families and two orders of the Stylommatophora sheds no light on the problem of origin and early evolution of the group. The fact that the fossil genera are referable to extant families with very high confidence limits (Anthracopupa and Protodiscus) or high confidence limits (Dawsonella and Dendropupa) indicates that by the first appearance in the fossil record of the Stylommatophora, their radiation already had reached a plane of stability. The Tornatellinidae (Anthracopupa), although complex in many features, have a number of generalized anatomical features and are placed as perhaps the most generalized group within the Orthuretha. In contrast, the Enidae (Dendropupa) show many advanced features, and some taxa have evolved "pseudosigmurethrous" features, which apparently have enabled them to colonize semiarid areas successfully. The Enidae are thus probably one of the most advanced families of the Orthurethra. The superfamily Pupillacea ("Pupa" bigsbii) is yet a third family-level group of the Orthurethra.

The fourth taxon of the Stylommatophora found in the late Paleozoic, the family Discidae, belongs to the arionid complex, which is one of the most primitive groups of the Order Sigmurethra. The Discidae is probably one of the more advanced families of the Arionacea, but it still belongs to a probable stem group of the Sigmurethra. The above data on landsnail phylogeny are summarized from Solem (1978b).

Possible reasons for the absence of the remaining land-snail ordinal groupings are worth considering. The absence of both freshwater and terrestrial basommatophoran snails until the Jurassic-Cretaceous boundary, despite the recording of freshwater mollusks since the Devonian, suggests a later period of evolution. The land-snail order Mesurethra, the suborder Holopodopes, and the suborder Holopoda (the latter two are subdivisions of the Sigmurethra) all first appear in the Upper Cretaceous of Europe. These fossils, like the Paleozoic taxa, also are assignable to extant families, and they indicate that a high level of differentiation had been achieved and stability reached by the time of their appearance. In general, most of these taxa have efficient water-conservation devices; thus, they are able to inhabit drier areas than the members of the order Orthurethra (except the arid-zone pupillaceans and enids) and the superfamily Arionacea. Most arionids still inhabit flood plains or very moist forests. They, and the terrestrial prosobranchs such as the Helicinidae, can be active only during periods of nearly saturated humidity. In contrast, the higher Sigmurethra, because they evolved better water-conservation mechanisms, can be active in drier conditions and can more effectively retreat from both floods and drying niches. Hence the higher Sigmurethra would be less likely to be preserved as fossils than would the flood-plain-inhabiting Orthurethra and Arionacea. Exceptions to the above generalities occur, but differences in both habitat selection and mobility result in different chances of successful preservation for the ordinal groups that are present and for those that are absent from the Paleozoic deposits. The absence to date of land-snail fossils from the Early Permian to the Late Jurassic might well conceal the actual evolution of the missing ordinal units; we cannot exclude the possibility that higher forms were present in the late Paleozoic but were not preserved in the limited record because of habitat selection.

\section{ECOLOGICAL SIGNIFICANCE}

We can offer a few observations and speculations on the probable ecology of the Paleozoic land snails. The most abundant materials are those of Anthracopupa in the Little Captina Limestone Member of the Monongahela Formation and Dendropupa in the tree stumps of the Joggins Formation. Dawsonella is abundant in restricted Illinois localities. All other specimens are rare in comparison.

The occurrence of fresh and worn fossils of Anthracopupa in the same locality finds modern equivalents among pupillid land snails of North America. Streamdrift windrows in late spring often contain material of the same species in two conditions. Specimens without periostracum whose surfaces have been worn or eroded are mingled with fresh undamaged specimens. The former, after death, may have sat in standing water with decaying leaves for a short to medium period. The weak humic acids and (or) bacterial action could have removed the periostracal covering. When a subsequent rain storm washed them into a stream, they could have been joined by individuals that died at the same time but then laid in dry leaf litter and did not lose the periostracum or by live specimens that, after being washed into the stream and stranded, died on the spot. The thanatocoenoses of Anthracopupa could have originated in a similar way.

The postulated method of deposition is fully consistent with conclusions reached through study of the lithology and stratigraphy of the Dunkard beds (Berryhill, 1963, p. 80-90). Seasonally high rainfall could have flushed downstream the dead snails accumulated during preceding drier periods. A bubble of air inside the shell, trapped and held by the protruding apertural barriers, could have enabled the shell to 
float for a long time. Only breaking of the shell to release the air bubble or gradual filtering in of fine sediment would have reduced buoyancy and caused the shell to sink to the bottom. Wind drift, or eddy effects along stream margins could have caused the tiny shells to accumulate in shore drift and thus be subject to burial and preservation during the next rainstorms. This theory accounts for the presence of minute land snails in such drift deposits. The observed paucity or absence of larger shells in the drift deposits is also consistent with this environment. A larger shell, $6 \mathrm{~mm}$ or more in diameter, or a shell without any apertural barriers is far more apt to have any air bubble escape and thus lose buoyancy. In addition, the larger shells can more easily crash into one another and break, whereas the surface tension of the water film tends to keep the minute specimens apart and thus undamaged. This inference is supported by the high percentage of the large snails represented in drift deposits by broken fragments.

Carroll (1967, p. 112) has postulated that the standing fern trees of the Joggins were inundated by heavy floods and that vertebrates wandered onto the drying mud and into the decaying, partly buried tree trunks. A second flood would then bury and preserve the unlucky colonizers. Massive deposits of fragments of Dendropupa are consistent with this scenario, particularly if Dendropupa, rather than being a leaf-litter inhabitant, might have been associated with the tree-trunk-base debris in the fern forests. Such an ecological niche would be consistent with that of modern terrestrial snail taxa of equivalent size.

A possible present-day analog to the Dendropupa thanatocoenose is present in modern tropical forests. There, a variety of cyclindrical land snails $8-20 \mathrm{~mm}$ long inhabit the buttress and tangled root litter accumulations of large trees. The environment is somewhat acidic, turnover rates are high, and dead shells fragment quickly. The soil generally is thin and gravelly, so that runoff after heavy rains tumbles dead shells and gravel fragments, further breaking the shells. Accumulation of these in rock crevices, streamside drift, low tree holes, or in a buttress of a tree are all common phenomena.

In general, the taxa that have depositional associations in freshwater limestones similar to that of Anthracopupa, live today in open loose litter, under bark of decaying logs, and in or slightly above floodplain levels. They do not live in swamps or in continuously inundated areas, but in the seasonally flooded areas and humid forests adjacent to the flood levels. Some taxa have adapted to drier plains habitats, but the time their adaptation occurred is unknown. The tree-associated larger shelled taxa of the tropics today are found mostly in monsoon or rain forest areas. We cannot assume from the snails that the Joggins section had a higher and less seasonal rainfall regime than the Dunkard. However, the snails and repeated widespread thin limestones of the Dunkard may indicate that the limestones were deposited in an area having a mildly seasonal rainfall pattern.

Land snails of the modern helicinid genus Oligyra commonly compose a large proportion of the streamdrift deposits in Texas and drier parts of Mexico. Apparently they can be transported tens if not hundreds of kilometers during periodic floods resulting from cloud bursts, as the thick shells are less easily damaged than the more fragile shells of the pupillid taxa also found in the semiarid regions of Texas and Mexico. The shells of Oligyra are common in these deposits, but their opercula are rarely found. An air bubble caught in the shell permits long-distance transport, whereas the flat solid operculum is far less apt to be stream transported.

Thus, all three of the abundant genera of Paleozoic land snails can be matched with modern equivalents in terms of probable ecology and chances for preservation. All three were transported moderate to long distances by floods. Although most frequently such transportation today results in the transport of dead shells or in the death of any live snails picked up by the floodwaters, occasionally to frequently, floodwaters successfully transfer live snails from one area to a site many kilometers downstream. Establishment of new colonies by stream transport is one of the more usual ways in which flood-plain land snails are dispersed. Such transport can, of course, happen only in a downstream direction. Even local movement of land snails can lead, in a relatively short time, to great range extensions. The last major glaciation in North America extended as far south as central Indiana and Illinois as late as 25,000 years ago. Yet land-snail species such as Vitrina limpida (Gould), Discus cronkhitei (Newcomb), Punctum minutissionum (Lea), Vertigo ventricosa (Morse), and Cionella lubrica (Müller) have managed to reach the shores of Hudson Bay, a distance of at least $2,000 \mathrm{~km}$, since the retreat of the glacier. Such movement has been basically against streamflow, so that flooding transport has not been a positive factor in their dispersal.

Although we present no new botanical data, speculation as to the factors that permitted the initial explosive radiation of land snails is very much in order. The first appearance of a diversity of land snails in the Joggins section (late early Pennsylvanian) of Nova Scotia is highly dramatic and was a point emphasized repeatedly by Sir William Dawson. The limited paleobotanical data do not identify any dramatic shift in 
vegetation types that coincides with or slightly precedes this gastropod crawl onto land, but three trends in the evolution of Euramerican flora at about this time seem to have provided, in combination, conditions favorable to the colonization of land by snails.

The three floristic trends were the increase in arborescent plants at the expense of herbaceous types, the development of laminate foliage types in several lineages, and (associated with the development of laminate foliage types) development of a continuous leaf-shedding pattern typical of modern evergreen plants in addition to the already existing seasonal leaf-shedding pattern typical of modern deciduous plants (T. Phillips, oral commun., 1976). Although the arborescent pattern of growth is known to have been present by the Late Devonian, it did not become common until the latter part of the Mississippian. Plants showing these trends gradually became more common through the Mississippian.

The combined net effect of these changes for potential litter dwellers would have been considerable. Broadening of the higher leaves provides shade and substantially retards the dessication caused by exposure to direct sunlight. Broad leaves also add, through transpiration, considerable moisture to the shaded air layers. The trend towards continuous leaf shedding has two effects: continual addition of raw material to the litter and continual provision of better shade cover for the litter. These relatively simple trends would have combined to provide a moist, well-shaded, and continuously replenished litter-a favorable environment for moisture-loving snails. Thus, the sudden explosive appearance of land snails in the Westphalian $B$ could have been triggered by the above-mentioned botanical trends that produced a suitable continuously moist litter habitat. In contrast, at the same time, the Gondwana and Cathaysean floras were still shedding leaves seasonally rather than continuously. Thus, the fact that the first land snails found in the fossil record of the Gondwana areas are much younger than those found in the Joggins section might indicate that the land there was not favorable to snail colonization until the flora changed. However, this idea pushes our speculations to the outer limit.

Careful attention to earlier limestones that may have been deposited in freshwater ponds, the inferred habitat of the Anthracopupa assemblages, would provide the best chance of locating land-snail fossils older than those in the Joggins section. The chances for successful preservation of snails in these habitats would be much greater than those for the very unusual preservation of snails in tree stumps found in the Joggins. We would not be surprised if study of such earlier limestones did reveal traces of earlier land snails, but we are not optimistic that this hunt will prove successful. Breakdown of litter to a size easily attacked by bacteria and fungi existed on land at the death of the earliest herbaceous plants. However, dry seasons, the absence of moisture-preserving shelter sites, seasonal rather than continuous additions to the litter, and resulting moisture-deficit problems would effectively have prevented colonization by most snails. To what extent the first land plants were restricted to continuously moist habitats or adjusted to seasonality of dryness is unknown, as is the identity of the early plantdetritus feeders. The Viséan may well have been the first suitable opportunity for snails to colonize the land, and the Westphalian $B$ records may represent the initial surge of land-snail taxa.

\section{BIOGEOGRAPHIC SIGNIFICANCE}

The occurrence of Anthracopupa in an area from Vienna, Austria, to the Illinois-Indiana border and the apparent presence of Dendropupa in eastern Canada, Poland, and France provide additional evidence that Europe and North America were joined together during the late Paleozoic. During the approximately $75,000,000$ years separating the earliest and latest records for Anthracopupa, it could easily have dispersed across this range of nearly $5,500 \mathrm{~km}$. The dispersal of land snails across $2,000 \mathrm{~km}$ in North America during less than 25,000 years is evidence enough of their dispersal powers. We also would point out that bird (or even pterodactyl) accidental transport was not available to the Pennsylvanian land snails. Although some freshwater prosobranch snails have been known to emerge alive from the crop of a duck, and thus could be transported in bird stomachs as well as on bird feet, no pulmonate snails, which lack the protective operculum, have been known to undertake a similarly safe passage. The comparatively rare giant insects of the Pennsylvanian coal forests conceivably could have accidentally transported water snails, but resorting to such helpful chauffeurs is unnecessary to explain the distributions.

The comparative distributions of the Paleozoic and appropriate modern taxa are highly diverse. We discuss these in phylogenetic order. The modern Helicinidae are basically tropical and markedly disjunct in distribution; Southeast Asia to Polynesia and Central America and the West Indies are the two centers of diversity. A few genera, such as Pseudhelicinia, are endemic to South America, and a few species live in Florida or the southeast United States (Helicina Lamarck, 1799, Oligyra Say, 1818, and Lucidella Swainson, 1840). One genus, Hendersonia A. J. Wagner, 1907 , is a Holarctic relic that still can be found in scat- 
tered colonies through northern Iowa, southern Minnesota, Wisconsin, Michigan, and Illinois. From the structure of the operculum and the radula, Hendersonia is considered to be a primitive helicinid, somewhat related to the Japanese endemic Waldemaria. Fossil species assigned to Hendersonia are known from the Paleocene of Wyoming and Miocene of Oregon (Pilsbry, 1948, p. 1087). Thus, the presence of Dawsonella in Illinois during the late Paleozoic falls within the fringes of current geographic range.

The Tornatellinidae, except those transported by humans, are currently limited to the islands of Polynesia, Micronesia, and Juan Fernández (see Cooke and Kondo, 1960, p. 22-31). The centers of speciation are the Austral Islands (35 species), Hawaii (152 species), and Juan Fernández (19 species). Only a few small arboreal genera and species are widely distributed. There is a "***tenuity of relationship between the larger groups that indicates either great age and long isolation of the groups or destruction of the direct links leading to the highly variegated forms of today, or both" (Cooke and Kondo, 1960, p. 45). The discovery of late Paleozoic Anthracopupa in Illinois, Ohio, Pennsylvania, Nova Scotia, and Europe is thus quite an extension in geographic range. The only other known fossil tornatellinid is Protornatellina isoclina (White, 1895) from the Cretaceous of Wyoming. Polynesia today is an important center of snail diversity, harboring the relic land-snail families Endodontidae, Partulidae, and Amastridae and the achatinellid-tornatellinid complex.

The Pupillidae and other vertiginid families are mostly worldwide in distribution. No meaningful observations of changed distribution are possible, particularly in view of the tentative nature of our classifying "Pupa" bigsbii in the Pupillacea and its unique occurrence.

The Enidae are distributed in the Palearctic, China, India, and marginally southeast Asia and Indonesia; single taxa are in northern Australia, New Hebrides, and New Caledonia. A modest radiation in Africa completes their modern known range. The Nova Scotia record presents quite a different picture. It raises questions as to which group might have displaced the Enidae from North America, what group is the modern ecological equivalent in North America, and what special niche is occupied by the enids in the Old World. We do not have satisfactory answers to these questions and can only point them out as worthy of investigation.

Today the Discidae is a strictly Holarctic group containing only a few species. The greatest generic diversity is in North America, where humid montane areas or at least hill country contain the greatest variety of forms. Essentially no shift in distribution has taken place since Protodiscus evolved.

To summarize, the changes in biogeographic patterns from late Paleozoic to Holocene range over a spectrum; they include no change (Discidae); worldwide distribution (Pupillacea); slight southern shift and separation into two centers of diversity, one in the Eastern Hemisphere and one in the Western Hemisphere (Helicinidae); displacement from North America to the Old World (Enidae); and isolation today on the outer islands of the Pacific (Tornatellinidae). More detailed discussion of comparative distribution through time has been given by Solem (1977).

\section{REGISTER OF LOCALITIES FOR MONONGAHELA-DUNKARD GASTROPODS}

The occurrence of well-preserved gastropods at many of localities in the northern part of the Dunkard basin was reported by Yochelson (1975). His list by no means gives all the localities at which lands snails may be found but is representative of the geographic distribution of these fossils.

Repeated below are locality data for those specimens from U.S. Geological Survey collections that have been illustrated or measured. Localities for additional collections of land snails in the Field Museum of Natural History, Chicago, are given here.

U.S. Geological Survey

24827-PC Clark Hill section of Cross (1950). Poorly exposed limestone in roadside ditch at altitude of approximately 1,300 feet $(396 \mathrm{~m})$, just below crest of hill, center SW $1 / 4$ sec. 16, Salem Twp., Monroe County, Ohio. Nineveh Limestone Member, Green Formation, possibly unit 21.

24836-PC In ravine on north side of Deep Run Road, extreme west sec. 26, Pease Twp., Belmont County, Ohio. Basal part Little Captina Limestone Member, Monongahela Formation.

24840-PC Pasture on south side of Ohio Route 148, just east of junction with Ohio Route 145 , in gully below bench, $30 \mathrm{~m}$ south of road, center of west line, sec. 28, Washington Twp., Belmont County, Ohio. Little Captina Limestone Member, Monongahela Formation.

24846-PC Ayers limestone quarry in $\mathrm{SW}^{1 / 4}$ sec. 19, Pease Twp., Belmont County Ohio. 
Thin limestone $0.6 \mathrm{~m}$ below base of main bed of "Lower Washington Limestone Member," Washington Formation.

24850-PC Pasture on south side of Ohio Route 148, center of west line, sec. 28, Washington Twp., Belmont County, Ohio (re-collection of 24840-PC). Little Captina Limestone Member, Monongahela Formation.

24851-PC North side of cut on unnamed secondary road east of Henderson Avenue. (highway 18$), 0.68 \mathrm{~km}$ southwest of sewagedisposal plant, Washington West quad., Washington County, Pa. Uniontown Formation, Monongahela Group.

24854-PC In the bank of Deep Run on northwest side of county road $2,0.72 \mathrm{~km}$ east of Ohio Route 798, Belmont County, Ohio (re-collection of 24836-PC). Little Captina Limestone Member, Monongahela Formation.

24855-PC Ayers limestone quarry in $\mathrm{SW}^{1 / 4}$ sec. 19, Pease Twp., Belmont County, Ohio (recollection of 24846-PC). "Lower Washington Limestone Member," Washington Formation.

24856-PC In bank on south side U.S. Route 40 behind old house at " $\mathrm{S}$ " bridge which is also point of divergence of $\mathrm{Pa}$. Route 221, Washington County, Pa. "Lower Washington Limestone Member," Washington Formation.

24857-PC B\&O Railroad cut at Washington, Pa., 1.1 $\mathrm{km}$ northwest of mosque in Washington Cemetery, Washington County, Pa. "Lower Washington Limestone Member," Washington Formation.

Field Museum of Natural History

[Description of locality, collector, date of collection.

Comments on possible geologic occurrence are given in brackets.]

I-1 Scott's Cut on the B\&O Railroad) about 1 mile $(1.6 \mathrm{~km})$ northwest of Warnock, Belmont County, Ohio. Lowest limestone bed (on the east side of the cut). P.D. Moore. July 4-6, 1925. [Upper part of Monongahela Group, possibly Uniontown Formation.]

I-2 Scott's Cut (on the B\&O Railroad) about 1 mile $(1.6 \mathrm{~km})$ northwest of Warnock, Belmont County, Ohio. Second limestone bed containing fossils in this cut, about 25 feet $(7.6 \mathrm{~m})$, above the level of the tracks and beneath the shale zone that underlies the coal. P. D. Moore. July 6, 1925.

I-2 Same locality as above, but "from the middle limestone beds." [upper part of Monongahela Group, possibly Uniontown Formation or Waynesburg Formation of Dunkard Group.]

I-3 About 1 mile (or $1.6 \mathrm{~km}$ ) northwest of Warnock, Belmont County, Ohio. Scott's Cut (on the B\&O Railroad). From the black shale beneath the Waynesburg coal. July 8, 1925. [Probably part of the Gilboy Sandstone Member, Monongahela Formation.]

I-4 Along north side of Cadiz Road in bank beside road, $1 / 4$ mile $(0.4 \mathrm{~km})$ northwest of the village of Colerain, in southwest cor. SE $1 / 4$ sec. 14, Colerain Twp., Belmont County, Ohio. Altitude 1,300 feet (396 m). "Upper Washington limestone" (according to Wilbur Stout). Wilbur Stout, Geo. White, and P. D. Moore. July 1925. [Upper Washington Limestone Member," Washington Formation.]

I-4 Same locality as I-4 above. From "Lower Washington limestone." P. D. Moore. July 7,1925. [Probably "Lower Washington Limestone Member," Washington Formation.]

I-5 Near center sec. 30 , T $1 \mathrm{~N}, \mathrm{R} 9 \mathrm{~W}$, about $3 / 4$ mile $(1.2 \mathrm{~km})$ southwest of Constitution, Washington County, Ohio. At an altitude of about 985 $990 \mathrm{ft} .(300.2-301.8 \mathrm{~m})$ in the very top of the amphitheatre facing to the northwest. From the outcrop of the "Nineveh limestone" at the above place. The limestone here is about $10 \mathrm{in}$. $(25.4 \mathrm{~cm})$ thick and crops out for about $200 \mathrm{yd}$. $(183 \mathrm{~m})$ around the head of this sharp valley. Prof. R. W. Whipple and P. D. Moore. July 10, 1925 [Correlations in the upper part of the Greene Formation are uncertain; this may not be the Nineveh Limestone Member.]

I-6 From outcrop in bed of the small tributary, south of Cat Run and west of the old byroad in the west-central part of sec. 19, York Twp., Belmont County Ohio. From the black limy shale about $6 \mathrm{ft} .4 \mathrm{in}$. $(1.9 \mathrm{~m})$ above the "Fulton green shale" outcrop in this gully. P. D. Moore. July 8, 1925. [Probably from the Little Captina Limestone Member, Monongahela Formation.]

I-7 The very top of the little hill just east of the center $\mathrm{SE}^{1 / 4} \mathrm{SW}^{1 / 4}$ sec. $27, \mathrm{~T} 2 \mathrm{~N}, \mathrm{R} 9 \mathrm{~W}$; about 6 miles $(9.6 \mathrm{~km})$ southwest of Marietta, Ohio. South of the old railroad and from just inside the fork of the roads about $1 / 4$ mile $(0.4 \mathrm{~km})$ east of the above location, in the pasture; also along the road in the north-central part of 
SW $1 \frac{1}{4}$ sec. 21. Prof. R.W. Whipple and P. D. Moore. July 13, 1925 [Possibly Dunkard Group.]

I-8 From limestone exposure in road $2 / 5$ way up hill, on east bank of Muskingum River, 1 1/2 miles $(2.4 \mathrm{~km})$ southeast of the mouth of Bear Creek, northwest of Marietta, Ohio. Some specimens are from boulders in creek bed. This is most probably No. 9 of the section given by Stauffer and Schroyer (1920, p. 127) "Section of east bank of Muskingum River, $11 \frac{1}{2}$ miles southwest of mouth of Bear Creek." P.D. Moore. July 12, 1925 [Near the top of the Monongahela Group.]

\section{REFERENCES CITED}

Alison, D., and Carroll, R., 1972, Catalogue of type and figured specimens, fossil vertebrates, invertebrates and plants in the Redpath Museum, McGill University: Montreal, Redpath Mus., 173 p.

Baker, H. B., 1963, Anthracopupa and Maturipupa: Nautilus, v. 76 , no. 3 , p. 110 .

Barlow, J. A., ed., 1975, Proceedings of the First I. C. White Memorial Symposium "The age of the Dunkard": Morgantown, W. Va., West Virginia Geol. and Econ. Survey, 352 p.

Bell, W. A., 1944, Carboniferous rocks and fossil floras of northern Nova Scotia: Canada Geol. Survey Mem. 238, 277 p., 74 pls.

Berryhill, H. L., Jr., 1963, Geology and coal resources of Belmont County, Ohio: U.S. Geol. Survey Prof. Paper 380, 113 p.

Berryhill, H. L., Jr., Schweinfurth, S.P., and Kent, B.H., 1971, Coal-bearing Upper Pennsylvanian and Lower Permian rocks, Washington area, Pennsylvania: U.S. Geol. Survey Prof. Paper $621,47 \mathrm{p}$.

Bradley, F. H., 1870, Geology of Vermilion County: Illinois Geol. Survey, v. 4, p. 241-265.

-1872, Description of two new land snails from the coal measures: Am. Jour. Sci., ser. 3, v. 4, p. 87-88, 2 figs.

1874, Note on Anomphalus meekii: Am. Jour. Sci., ser. 3, v. 7, p. 151.

Calver, M. A., 1969, Westphalian of Britain: Cong. Internat. Stratigraphie et Géologie Carbonifére, 6th, Sheffield, England, 1967, Compte Rendu, v. 1, p. 233-254, 16 figs.

Carroll, R. L., 1967, Labyrinthodonts from the Joggins Formation: Jour. Paleontogy, v. 41, no. 1, p. 111-142, 26 figs.

Clapp, G. H., 1920, A new species of Pyramidula from Alabama and notes on $P$. cumberlandiana with new varieties: Nautilus, v. 34 , pt. 1 , p. $23-26$, pl. 1.

Cooke, C. M., and Kondo, Yoshio, 1960, Revision of Tornatellinidae and Achatinellidae (Gastropoda, Pulmonata): Bernice P. Bishop Mus. Bull. 221, 303 p., 123 figs.

Copeland, M. J., 1957, The arthropod fauna of the upper Carboniferous rocks of the Maritime Provinces: Canada Geol. Survey Mem. 286, 110 p., 21 pls.

Cox, L. R., 1926, Anthracopupa britannica sp. nov., a land gastropod from the Red Beds of the uppermost Coal-Measures of northern Worcestershire: Geol. Soc. London Quart. Jour., v. 82 , p. 401-410, 4 figs.

- 1927, Bernicia praecursor gen. and sp. nov., a lower Carboniferous freshwater gastropod: Geol. Mag., v. 54, p. 326-328, 1 fig.

1953, Gastropoda from the Karroo Beds of Southern Rhodesia: Geol. Mag., v. 90, no. 3, p. 201-207, 2 figs.
Cracraft, Joel, 1973, Continental drift, paleoclimatology, and the evolution and biogeography of birds: Jour. Zoology (London), v. 169 , p. $455-545,20$ figs.

Cross, A. T., Smith, W. H., and Arkle, Thomas, Jr., 1950, Field guide for the special field conference on the stratigraphy, sedimentation and nomenclature of the Upper Pennsylvanian and Lower Permian strata (Monongahela, Washington and Greene Series) in the northern portion of the Dunkard Basin of Ohio, West Virginia and Pennsylvania, September 8, 9, and 10, 1950, Privately printed, $104 \mathrm{p}$.

Cross, A. T., and Schemel, M. P., 1956, Geology and economic resources of the Ohio River valley in West Virginia-Pt. 1, Geology; Pt. 2, Economic resources: West Virginia Geol. Survey [Rept.], v. 22, pt. 1, 149 p.; pt. 2, 129 p.

Dawson, J. W., 1855, Acadian geology; an account of the geological structure and mineral resources of Nova Scotia and portions of the neighboring provinces of British America: 1st ed., Edinburgh, 388 p.; 2nd ed., 1868, 694 p. (3d and 4th ed. repub. without change, 1878, 1891).

1860 , On a terrestrial mollusk, a chilognathous myriapod, and some new species of reptiles from the coal-formation of Nova Scotia: Geol. Soc. London Quart. Jour., v. 16, p. 268-277. (Communication read before the Society, Dec. 14, 1859.)

- 1867 , On the discovery of a new pulmonate mollusk (Zonites (Conulus) priscus, Cpr.) in the coal-formation of Nova Scotia, with a description of the species by Philip P. Carpenter: Geol. Soc. London Quart. Jour., v. 23, p. 330-333, 5 figs.

1880, Revision of the land snails of the Palaeozoic era, with descriptions of new species: Am. Jour. Sci., ser. 3, v. 20, p. 403415,15 figs.

1895, Synopsis of the air-breathing animals of the Palaeozoic in Canada, up to 1894: Royal Soc. Canada Proc. and Trans., 1894, v. 12, sec. 4, p. 71-98.

Feys, Robert, and Greber, Ch., 1964, Bassin Carbonifère et Permien d'Épinac et d'Autun: Cong. Internat. Stratigraphie et Géologie Carbonifère, 5th, Paris, 1963, Compte Rendu, v. 1, p. 45-52.

Fischer, Paul, 1885, Description d'une nouvelle espèce de Dendropupa, du terrain Permien de Saône-et-Loire: Jour. Conchyliologie, v. 33, pt. 1, p. 99-105, 1 fig.

George, T. N., and Black, W. W., 1971, Lexique stratigraphique international. Vol. 1, Europe. Fasc. 3a, England, Wales and Scotland. Part 3a VII, Lower Carboniferous (Dinantian): Paris, Centre Natl. Recherches Sci., 416 p.

Grabau, A. W., and Shimer, H. W., 1909, Gastropoda, in North American index fossils; Invertebrates, v. I: New York, p. 582823.

Hacquebard, P. A., 1972, The Carboniferous of eastern Canada: Congrès Internat. Stratigraphie et Géologie Carbonifère, 7th, Krefeld, 1971, Compte Rendu, v. 1, p. 69-90.

Harry, H. W., 1951, Growth changes in the shell of Pythia scarabaeus (Linne): California Zool. Club Proc., v. 2, pt. 2, p. 1-14. 10 figs.

Henderson, Junius, 1935, Fossil non-marine Mollusca of North America: Geol. Soc. America Spec. Paper 3, 313 p.

Hintze, Egon, 1933, Anthracopupa rothenburgensis n. sp. und ein Helicide (?), zwei Landschnecken aus dem Obercarbon: Centralbl. Mineralogie, Geologie, Paläontologie, Abt. B, no. 4, p. $239-250$.

Knight, J. B., 1941, Paleozoic gastropod genotypes: Geol. Soc. America Spec. Paper 32, 510 p., 96 pls., 32 figs.

Knight, J. B., Batten, R. L., and Yochelson, E. L., 1960, [Descriptions of Paleozoic gastropods], in Moore, R. C., ed., Treatise on invertebrate paleontology, Part I, Mollusca 1: New York 
and Lawrence, Kans., Geol. Soc. America and Univ. Kansas Press, p. I169-I331, figs. 89-216.

Kobelt, Wilhelm, 1902, Die Familie Buliminidae: Nürnberg, Bauer and Raspe, p. [397]-1051, pls. 71-133. (Systematisches conchylien-cabinet von Martini und Chemnitz, Bd. 1, Abt. 13, pt. 2.)

Lipiarski, Ireneusz, 1971, Dolnopermska flora martwicy karniowickiej koto Krakowa: Poland Inst. Geol. Prace, v. 58, p. 5112,17 pls.

Matthew, G. F., 1895, On the organic remains of the Little River Group, No. II: Royal Soc. Canada Proc. and Trans., v. 12, pt. 4, p. 89-100, pl. I.

Morrison, J. P. E., 1946, The nonmarine mollusks of San Jose Island, with notes on those of Pedro González Island, Pearl Islands, Panamá: Smithsonian Misc. Colln., v. 106, no. 6, 49 p., 3 pls.

Odhner, N. Hj., 1922, Mollusca from Juan Fernandez and Easter Island, in Skattsberg, C. J. F., ed., The natural history of Juan Fernandez and Easter Island: Uppsala, Almqvist and Wiksells Boktryckeri, v. 3, pt. 2, p. 219-254, pls. 8-9, 24 figs.

Owen, Richard, 1859, Palaeontology, in Encyclopaedia Britannica [8th ed.], v. 17, p. 91-176.

Panow, E., 1936, Permokarbónska fauna martwicy karniowickiej: Polskie Towarz. Geol. Rocznik (Soc. Géol. Pologne Ann.), v. 12 , p. $36-42$, pl. 1

Parodiz, J. J., 1969, The Tertiary non-marine Mollusca of South America: Carnegie Mus. Annals, v. 40, 242 p., 7 maps, 18 pls.

Peck, J. H., Jr., and McFarland, H. B., 1954, Whitfield collection types at the University of California: Jour. Paleontology, v. 28, no. 3, p. 297-309, pl. 29.

Pilsbry, H. A., 1895, Manual of conchology; structural and systematic: Philadelphia, Pa., ser. 2, v. 9, 366 p., 73 pls., 126-p. index. -1903-1904, Manual of conchology; structural and systematic: Philadelphia, Pa., ser. 2, v. 16, 329 p., 68 pls.

1916-1935, Manual of conchology; structural and systematic: Philadelphia, Pa., ser. 2, v. 24-28 (see especially v. 24 (19161918), 380 p., 49 pls. v. 27, (1926) pt. 108, p. 177-369, pls. 19 $32)$.

-1946-48, Land Mollusca of North America (north of Mexico): Acad. Nat. Sci. Philadelphia Mon. 3, v. 2, pt. 1 (1946) p. 1 520, figs. 1-281; pt. 2 (1948), p. 521-1113, figs. 282-585.

Pilsbry, H. A., and Cooke, C. M., 1914-1916, Manual of conchology; structural and systematic: Philadelphia, Pa., ser. 2, v. 23, 302 p., 55 pls.

Poole, E. G., 1969, The stratigraphy of the Geological Survey Apley Barn borehole, Witney, Oxfordshire: Great Britain Geol. Survey Bull. 29, 103 p.

Poole, W. H., and others, 1970, Geology of southeastern Canada, in Geology and economic minerals of Canada: Canada Geol. Survey, Econ. Geology Rept. 1 (5th ed.), p. 228-304.

Pruvost, Pierre, 1957, Lexique stratigraphique international. Vol 1, Europe. Fasc. 4a, France, Belgique, Pays-Bas, Luxembourg. Part 4aII, Paléozoique Supérieur: Paris, Centre Natl. Recherche Sci., $255 \mathrm{p}$.

Revunova, K. E., 1938, [Some gastropods of the Tartarian stage from the basin of the Sukhona and Mezen Rivers]: U.S.S.R., Central Geol. Prospecting Sci. Research Mus. (Tschernyschew Mus.), Annals, v. 1, p. 66-74, pl. 24. (In Russian, with English summary.)

Richardson, G., and Francis, E. H., 1971, Fragmental clayrock (FCR) in coal-bearing sequences in Scotland and north-east England: Yorkshire Geol. Soc. Proc., v. 38, pt. 2, p. 229-260, pls. 19-22, 4 figs.

Rossouw, P. J., 1970, Freshwater Mollusca in the Beaufort Series of southern Africa: Internat. Symposium on Gondwana Strati- graphy and Paleontology, 2d, Capetown and Johannesburg, p. 615-616.

Runnegar, Bruce, and Newell, N. D., 1971, Caspian-like relict molluscan fauna in the South American Permian: Am. Mus. Nat. History Bull., v. 146, art. 1, 66 p., 27 figs.

Russell, L. S., 1947, A new locality for fossil fishes and eurypterids in the Middle Devonian of Gaspé, Quebec: Royal Ontario Mus. Palaeontology Contr., v. 12, 6 p., 3 figs.

Shaver, R. H., and others, 1970, Compendium of rock-unit stratigraphy in Indiana: Indiana Geol. Survey Bull. 43, 229 p.

Solem, Alan, 1959, Systematics and zoogeography of the land and freshwater Mollusca of the New Hebrides: Fieldiana-Zoology, v. 43 , nos. $1 / 2,359$ p., 38 figs., 34 pls.

1962, Notes on, and descriptions of New Hebridean land snails: British Mus. (Nat. History) Bull., Zoology, v. 9, pt. 5, p. 215-247, 2 pls., 17 text-figs.

1964, Amimopina, an Australian enid land snail: Veliger, v. 6 , pt. 3, p. 115-120, 4 figs.

1970, Malacological applications of scanning electron microscopy. I. Introduction and shell surface features: Veliger, v. 12 , pt. 4 , p. $394-400$, pls. $58-60$.

1972, Microarmature and barriers in the apertures of land snails: Veliger, v. 15, pt. 2, p. 81-87, 5 pls.

1973a, Apertural barriers in Pacific Island land snails of the families Endodontidae and Charopidae: Veliger, v. 15, pt. 4, p. $300-306,24$ figs.

1973b, A new genus and two new species of land snails from the Lau Archipelago of Fiji (Mollusca: Pulmonata: Endodontidae): Veliger, v. 16, pt. 1, p. 20-30, 21 figs.

1974, The shell makers: Introducing mollusks: New York, Interscience Publishers, 289 p., 12 pls., many text-figs.

1976, Endodontoid land snails from Pacific Islands (Mollusca, Pulmonata, Sigmurethra). Part I, Family Endodontidae: Chicago, Field Mus. Nat. History, 508 p.

1977, Shell microsculpture in Striatura, Punctum, Radiodiscus, and Planogyra (Pulmonata): Nautilus, v. 91, pt. 4, p. 149-155.

1978a, Biogeographic significance of land snails, Paleozoic to Recent: Oregon State Univ. Biol. Colloquium (in press).

1978b, Characteristics of the land snail family Discidae, Thiele, 1931: Veliger v., p. (in press.)

1978c, Classification of the land Mollusca, in Pulmonates. Vol. 2, Systematics, evolution, and ecology: London, Academic Press, p. 49-97.

Solem, Alan, and Lebryk, S., 1976, Apertural microprojection size correlations in pupillid and polygyrid land snails: Veliger, v. 19 , pt. 2, p. $115-120$.

Staesche, Karl, 1963, Übersicht über die Fauna des deutschen Rotliegenden (Unteres Perm). Pt. A, Wirbellose mit Ausschluss der Insekten: Stuttgarter Beitr. Naturkunde, no. 96, 7 p. 1969, Übersicht über die Fauna des deutschen Rotliegenden (Unteres Perm). Pt. D, Nachtrag zur systematischen Übersicht: Stuttgarter Beitr. Naturkunde, no. 198, 10 p.

Stauffer, C. R., and Schroyer, C. R., 1920, The Dunkard series of Ohio: Ohio Geol. Survey Bull. 22, ser. 4, 167 p., 14 pls.

Stopes, M. C., 1914, The "Fern Ledges" Carboniferous flora of St. John, New Brunswick: Canada Geol. Survey Mem. 41, 167 p., 25 pls.

Tilton, J. L., 1930, Plant and animal remains in the rocks at Oglebay Park, West Virginia: West Virginia Acad. Sci. Proc., v. 4 (Univ. Bull. ser. 31, no. 2), p. 100-118, pls 1-4.

Tozer, E. T., 1956, Uppermost Cretaceous and Paleocene non-marine molluscan faunas of western Alberta: Canada Geol. Survey Mem. 280, 125 p., 9 pls., 5 figs. 
Wenz, Wilhelm, 1938, Gastropoda, in Schindewolf, O. H., ed., Handbuch der Paläozoologie: Berlin, Gebrüder Borntraeger (Lf. 1 (Bd. 6, 1), Teil 1, Allgemeiner Teil und Prosobranchia, p. 1-240, 471 figs. Lf. 3, 4 (Bd. 6, 1), Teil 2, 3, Prosobranchia, p. 241-480, 481-720, 1612 figs.)

White, C. A., 1883, A review of the nonmarine fossil Mollusca of North America: U.S. Geol. Survey Ann. Rept. 3, p. 403-550, pls. 1-32.

Whitfield, R. P., 1881, Notice of a new genus and species of airbreathing mollusk from the Coal-Measures of Ohio, and observations on Dawsonella: Am. Jour. Sci., ser. 3, v. 21, p. 125-128, 6 figs.

1891, Contributions to invertebrate paleontology [Ohio]: New York Acad. Sci. Annals, v. 5, p. 505-620, pls. 5-16.

1895, Contributions to the paleontology of Ohio: Ohio Geol. Survey, v. 7, p. 407-494, 13 pls.

Willman, H. B., and others, 1975, Handbook of Illinois stratigraphy: Illinois State Geol. Survey Bull. 95, 261 p., 176 figs.

Yen, Teng-Chien, 1949, Review of Palaeozoic non-marine gastropods and description of a new genus from the Carboniferous rocks of Scotland: Malacolog. Soc. London Proc., v. 27, pt. 6, p. 235-240, pl. 12A.

1952, Molluscan fauna of the Morrison Formation: U.S. Geol. Survey Prof. Paper 233-B, p. B 21-B51, pls. 3-6, 1 fig.

Yen, Teng-Chien, and Reeside, J. B., Jr., 1946, Fresh-water mollusks from the Morrison Formation (Jurassic) of Sublette County, Wyoming: Jour. Paleontology, v. 20, no. 1, p. 52-58, 12 figs.

Yochelson, E. L., 1975, Monongahela and Dunkard nonmarine gastropods, in Barlow, J. A., ed., Proceedings of the First I. C. White Memorial Symposium "The age of the Dunkard": Morgantown, W. Va., West Virginia Geol. and Econ. Survey, p. 249-263.

Yochelson, E. L., and Saunders, B. W., 1967, A bibliographic index of North American late Paleozoic Hyolitha, Amphineura, Scaphopoda, and Gastropoda: U.S. Geol. Survey Bull. 1210, 271 p.

Zilch, Adolf, 1959-1960, Gastropoda; Teil 2, Euthyneura, of Handbuch der Palaözoologie, Bd. 6: Berlin, Gebruder Borntraeger, 834 p. (in 4 pts.), 2515 figs. (Zilch completed material prepared by Wilhelm Wenz, who died in 1945.) 


\section{INDEX}

[Italic page numbers indicate both major references and descriptions]

\section{A}

Page

Abida--

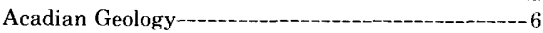

Achatinella --...- 22, 23

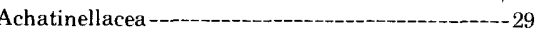

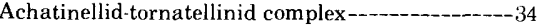

Achatinidae --

Acknowledgments -

Alcadia--

Algal mat--.-_-_.--27

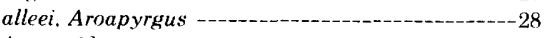

Amastridae - -

Amnigenia--o--

Amplovalvata -...--

Anauchen --_-_...--22

Anguspira --_-

picta-sculpture, apical +-

Anomphalus meeki --_-_-_-_-_-_- 25

Anthracopupa --.-- 2, 3, 5, 9, 10, 20, 24, 27, 28, 31 affinities-_-_...- 19, 20

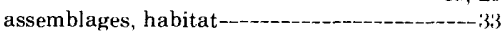
bigshii---_os

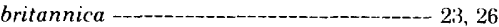
collections, Ohio -compared to Cyclophoridae---_-_-_compared to Dendropupa------_------ 20, 21 compared to Ellobiidae---_-_-_-_-_- 21 compared to Stylommatophora -- compared to Tornatellinidae-depositional associations --dispersal-----_--- 33 dunkardana -fossils - geographic range -Illinois-Indiana border --_-_-_-_-_.--133

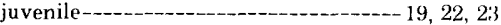
mode of preservation-_...- 19 ohioen sis--_-_-_-_ $4,5,15,20,23,24$, $25,26,27,29$; pls. 1,5 ,

$6,7,9$

measurements -.........-- 16

mode of preservation--

shape variation - 16,17

shell structure --_...-- 16

size variation -

variability ----_- 16,17

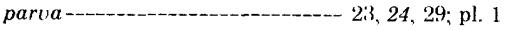

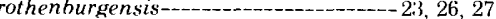

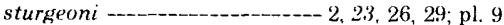

thanatocoenoses - -

vermilionensts -_-__-_-_ 23, 24, 25, 27, 29; pl. 1

Vienna, Austria--

sp --_-_-

Anthracopupinae --_._- 3, 20, 29

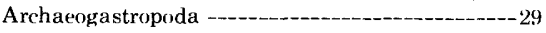

Archaeopteryx --_-_-_-_._-

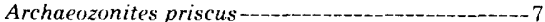

Archanodon -...-_

Archanodontidae - -

Arionacea --.-29, 31

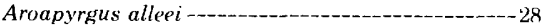

Aulacopoda -

Aulacospira----_-

Auriculella-

$-2 ;$

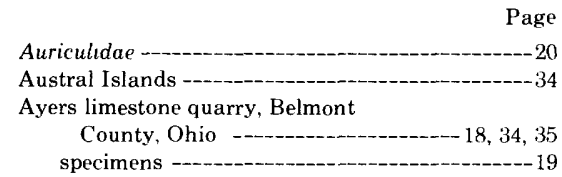

\section{B}

Baker, H. B., cited --

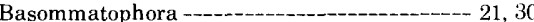
origin--

BelI, W. A., cited --

Belmont County, Ohio -------

Bensonella--...---.-- 22

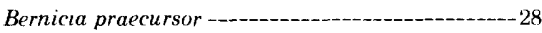

Big Creek Shale Member--
bigsbii. Anthracopupa -4

Dendropupa -- 2, 3, 6, 9, 19, 29, 31, 34; pls. 2, 8
Pupa -

bigshyi, Pupa---- 9

Birds, origin ---

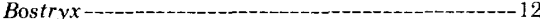

Boysidia --_-_- 22

Bradley, F. H., cited----- 12 quoted

Breezy Hill Limestone Member.

Cabaniss Formation --

britannica. Anthracopupa---_--------23, 26

Buliminus labrosus labrosus ---_-...-...------13

Bulimulidae-----_-_-_-_---_12, 13, 21 Austro-Pacific--_-_.

Neotropical --_-_._- 12

\section{$\mathrm{C}$}

Cabaniss Formation, Breezy Hill Limestone Member Kansas --_-..-.

Carbondale Formation, Herrin Coal Member -....- 4 Kewanee Group --

St. David Limestone Member-.............-28 Spring Lake Coal Member --_-_-_..-.

Carboniferous, Coal Measures, Little Vermillion River, Vermillion Co., Indiana -_...-_- 4

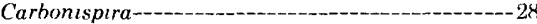
scotica--..-

Carpenter, P. P., cited ---_------ 7

Carroll, R. L.. cited--_-

Carychium--------- 21, 30

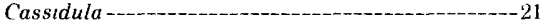

Ceres- Cos

Ceský Brod, Prague, Czechoslovakia --_-_-_----27

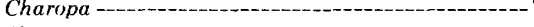

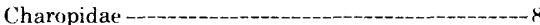

Chondrina -- Clonela lubrica-on

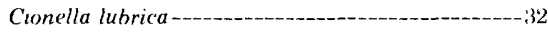

Clams, freshwater --_-_-_-_-_-

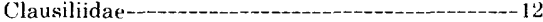

Coal beds, fossils --_-

Coal-Measures, South Joggins, Nova Scotia --_-_-...3

Coal mine, Vermillion $\mathrm{C}_{0}$., Ind -........-_.

Coal No. 4, Summum coal-_..._-_-_._. 4,5

Coal No. 6, Herrin coal--_Illinois section

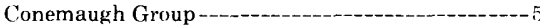

(Conulus) priscus, Zonites --_-_-_ 6, 7.9

Cooke, C. M., quoted -_-

Cracraft, Joel, quoted -_-_-_._._.

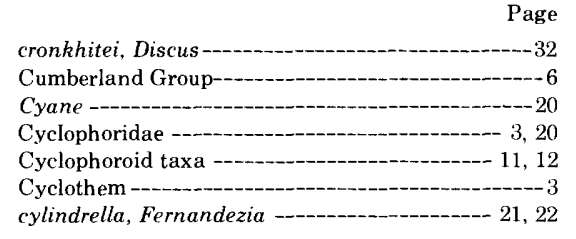

\section{D}

D’Aiguillon, Gaspé Peninsula, Quebec, Canada---28 Dawson, J. W., cited -- 3, 6, 7, 14, 27 quoted --_-_-_-_-_-_-_._-_-_-_-_.-- 6, 10 Dawsonella--_-_-_-_-_-_-_24, 25, 29, 31, 34 meeki--_-_-_-_-_-_-_-_, $3,25, ;$ pl. 10

Dawsonellidae --_---_-_-_----_-

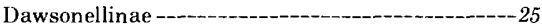

Dendropupa -- 2, 3, 6, 11, 12, 13, 26, 27, 28, 29, 31, 32 bigsbii--_-_._-_.-_. 9

Canada---.-_-

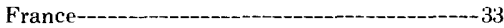

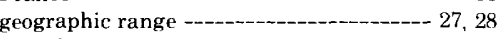

growth pattern---

grandaeva---.-------

grandaevus -...-

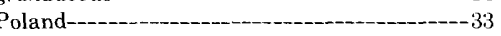

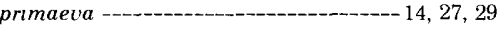

tenuistriata --.--- 6

thanatocoenose --_-_-_-_- 32

vetusta -- $3,6,10,15,24,26,27,29 ;$ pls. 4,8 mode of preservation--.---_- 18

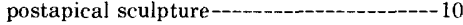
tenuistriata --_-_-_-_-

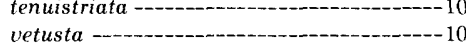
walchiarum -_-_-_ 14, 26, 27

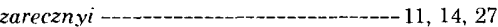

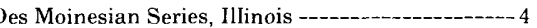
Iendropupinae -----_ 3, 13, 29 diminuta, Natıcopsis -__-_-_-_ 5, 15; pl. 1

Diotocardia --_-

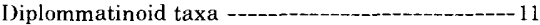
Discidae Holaretic --

Discus --.---.-.---

cronkhitet--_-_-

Draparnaudia--a-c-an

Iunkard basin--

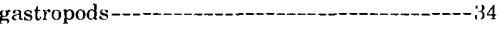

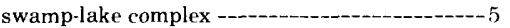

Dunkard beds------_-

Dunkard Group --_-

Greene Formation--

Uniontown Formation -

Washington Formation --_-_-_-

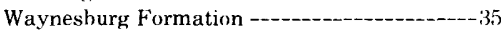

dunkardana. Anthracopupa-----------3, 5, 15; pl.

\section{$\mathrm{E}$}

Ecole de Mines-c.n-

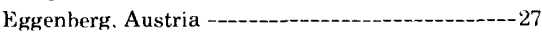

EIlobiidae---_--- 3, 20, 21, 23, 30 freshwater -...-_-_._-

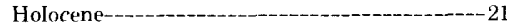

Ellobium-- Endodontidae--on

Endodontidae---

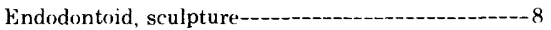




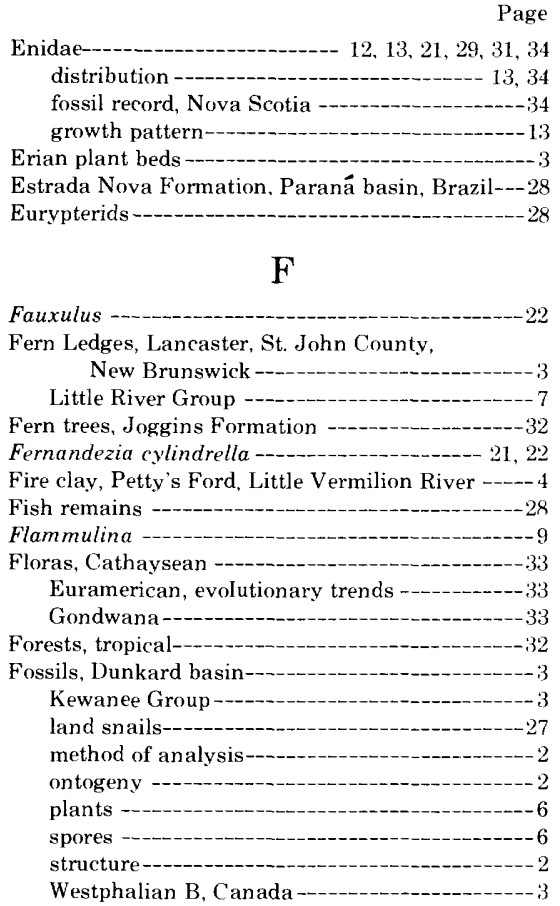

\section{G}

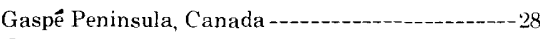
Gastrocopta pentodon----------------10

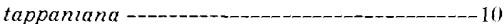
Gastropoda -Gastropods, I) unkard hasin --_-_-_-

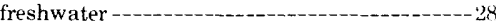
Paleozoic --_-_-_-

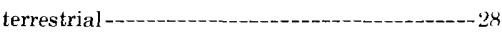
Illinois--_-

Gibbulina--_-_- 22

Gilboy Sandstone Member, Monongahela

Formation--Glaciation, North America --_-_-_._- 32 gonduanica, Hydrobia-------_-_--------28 gossei, Microceramus --_..-_...--

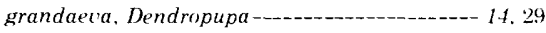
Strophella ---_--_- pl. 1 Strophites -grandae'us, Dendropupa-_-_--_Strophella ---_ 14; pl. 1 Strophites --_-_--_-- 3, 13, 14 Granopupa ------Greene Formation, Dunkard Group-----------5

Nineveh Limestone Member----_-...---- 16. 34 Gurley Collection ----Gylhotrachela ---

\section{$\mathrm{H}$}

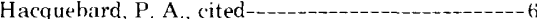

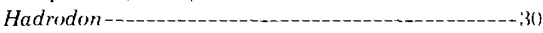

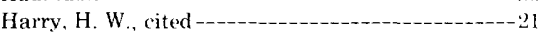
Hawaii --_

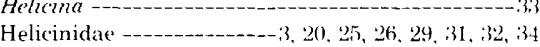
Helicinidae -
distribution, dis unct-- $3,20,25,26,29,31,32,34$ tropical -- dro

Helicoid, sculpture --

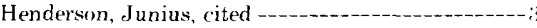
Hendersonta --.-- 33,34 Herrin coal, Coal No. 6--_-_-_-_-_Herrin Coal Member, Carbondale Formation ------ 1 Hodges Creek. Ill -Macoupin C (., Ill --Holopoda --.--.-- 1, 31

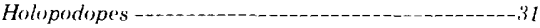

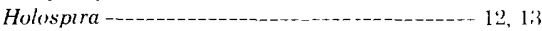
Hydrobia -

Page
gondwanica-10
Hydrobiidae -
Hypselostoma--

\section{I, J}

Illinois basin, limestones, freshwater

Illinois coal basinIntroduction isoclina, Protornatellina---_-_-_-_-_-_-_---34

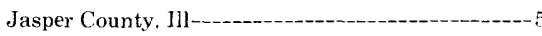
Joggins area, Nova Scotia --_-_-_-_-_-- 3, 31, 32 Joggins Formation, tree stumps ------------31

Journal de Conchyliologie--_-_-_-

Juan Fernández --

Jurassic-Cretaceous boundary --

\section{$\mathrm{K}$}

Kanawha Formation ----------

Karnovice Limestone, algal bed --_-_-_-_-_-_--27 isotopic composition --_--- 27 Iower limestone --_Poland------_-

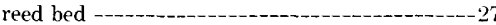

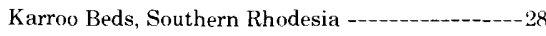
Keele beds, Hagley Park, Birmingham, England--26 Kewanee Group, Carbondale Formation -------4

Knight, J. B., cited--_-_-_-_ 6, 10, 11, 25 Kobelt, Wilhelm, cited----_--_Kondo, Yoshio, quoted --_-_-_._.

\section{L}

labrosus, Buliminus labrosus-----_-_----------1; labrosus, Bultmenus--_-_-_-_-_-_-_-_

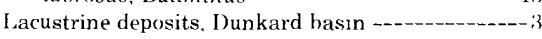

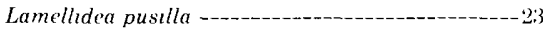

Land snail, England -German------Paleozoic, French --

I, and snails, apical sculpture---_-

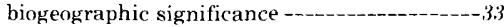
carboniferous ----- 1 deposition --....- 31, 32 deposits, Mexico --_Texas-distribution ---_-_-_. 33,34 diversity - Dunkard basin------

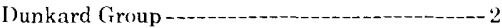

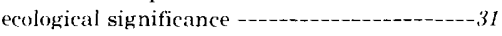
Fern Ledges, St. John, New Brunswick---.--- 6 flood plan, dispersal----fossil record--_-_-

Pennsylvaman---_- 1 fossils, Gondwana areas --geographic distribution ----Hudson Bay --

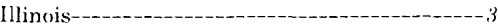
Illinois basin --

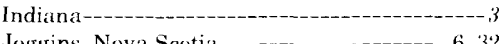

Joggins, Nova Scotia ------------- 6, 32 Karniovice. Krakow, Poland--_--_-_---27 Monongahela Group -New BrunswickNova Scotia --.-Ohio-roic - Paleozoc check lists -ecology -- local oceurrence-----Indiana Old World --

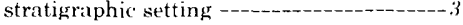
systematic list --

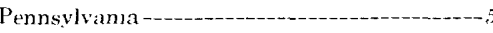
Pennsylvanian---_--_-_-_e

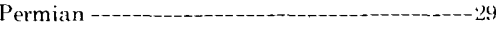

Petty's Ford, Little Vermilion River ---------4

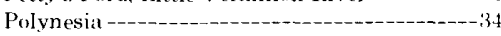

Page

Land snails-Continued postapical sculpture--

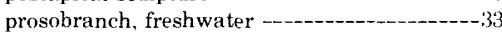
pupillid, North America------- 31

radiation, explosive - -

St. John, New Brunswick ---_-_-_-_-_-_-_-- 6

Vermillion County, Ind -----_-_-

Viséan-_------

West Virginia---_-_-

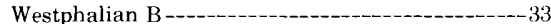

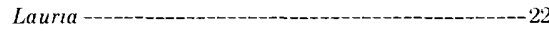

leat, Stenotrema --

Licharev. Boris, quoted-----------------27

Limestone, concretionary, Illinois section----------4 marine----_--_- 5

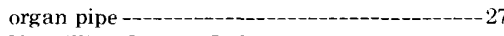

Vermillion County, Ind --_--_-_-_-_-

Limestone deposits, Belmont County, Ohio --------5

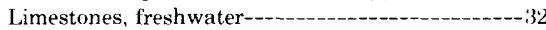
Illinois basin Jasper County. Ill-

lacustrine---_-----_-

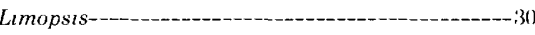

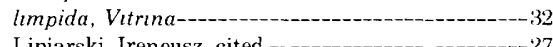
Lipiarski, Ireneusz, cited -_-_-_-_.--

Lissoacme - Captina Limestone Member,

limestone, rubbly - Member,

Monongahela Formation-----5, 23, 24, 31, 34, 35

thin sections ---_-_-

Little River Group, Fern Ledges -------_--------- 7

Fern Ledges. St. John. New Brunswick-------6

Little Vermilion River, Iand snails -----.-.
Locality refister, Field Museum of Natural History-U.S. Geological Survey-Monongahela-Dunkard Gastropods--_-_-_-_-34 Lower Beaufort beds, Weltevrede, South Africa ---28 I.ower Washington Limestone-.-------------5 Lower Washington Limestone Member --_---- 6, 18 thin sections --Loxonema par'a--

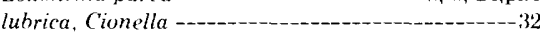
Lucidella --

Lyell, Charles--_-_-_-_-_-_- 6 Lymnaeidae -Lyrode's----

\section{M}

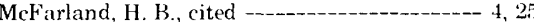

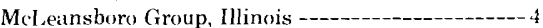
Mattoon Formation --

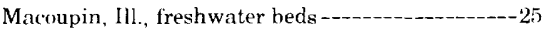
Jasper (Co., Ill-Macoupin County, Ill -_malachou. Omphaloptychia --_--_-_-_-_--27 Mangrove swamp---_-_---_30 Mansfelder Schichten, Halle, West Germany------26

Matthew, $G$. F cited-_- 6 quoted --_o--- 7, 14 Mattoon Formation, limestone, marine --Mcl eansboro Group --_---_--- 5 Reisner limestone Member--_-_-_-_._-_-_-_-_.

Maturipupa------_ 3, 20, 26 l'ermilionensis -meck. Anomphalus--_-..-_-_-_Dausonella --_-_-_-_, 2, 25; pl. 10 Mesauriculstra-----_Mesochtina--_-_Mesogastropods----_Mesonerituna---_-_- 29, 30

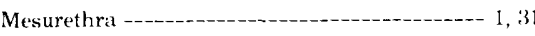
Microceramus--_-_-_- 10, 12 gosset--_-_-_-_- 12

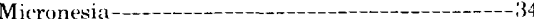
minutusstonum, Punctum---------_--_-_-_--_32 Modomorpha-------

Mollusks, freshwater--_-_-_.-_, 31

Monongahela-I)unkard Gastropods, locality registers --_-_-_-_-_-_-_-_-_-_-_-_-_----_34 
Monongahela Formation,

Gilboy Sandstone Member -----_-_-_- 35

Little Captina Limestone Member----- 5, 23, 24,

$31,34,35$

Monongahela Group -................. 5, 24, 35, 36 Uniontown Formation -

Monsoon areas-ormation -- Uniontown For

Morrison Formation, North America --.--_-- 29, 30

morsei, Vertigo --_--_-_-_-_-_-_-_-_-_-_-_-_---19

Museum National d'Histoire Naturel, Paris---_---26

Myalinidae - -

\section{$\mathrm{N}$}

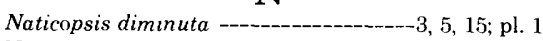

Neogastropods------ 12

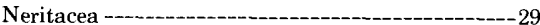

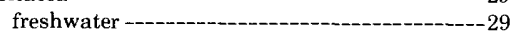

Great Britain ---_-_- 29

marine deposits --...- 29

terrestrial----_-

Newell, N.D., cited ---_-_-_-_-

Ninevah limestone----_-_-_-_-_-_-_-_-_-_-_-_-_35

Nineveh Limestone Member, Greene Formation 16, 34

Nipa palm swamp - -

notata, Triodopsis (Xolotrema) -

$\mathrm{O}$

oblongus, Tornatellides

Odontocyclas

Ohioensis, Anthracoupa--------3, 4, 5, 15, 20, 23, 24 $25,26,27,29 ;$ pls. $1,5,6,7,9$ Oligyra--_- $26,32,33$ orbiculata tropica --_-_-_-_-_-_-_-_-_-_-_ Omphaloptychia malachovi -._-_..--27

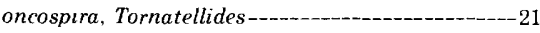

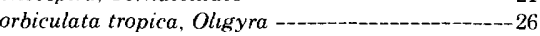

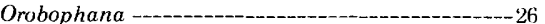

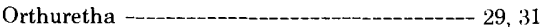

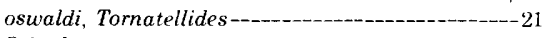

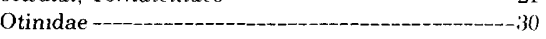

\section{$\mathrm{P}$}

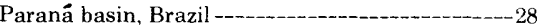

Partulacea --_-_-_.

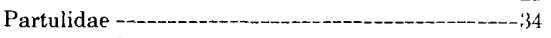

parva, Anthracopupa -_-_-_-_-_23, 24, 29; pl. 1

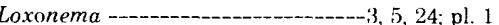

Peck, J. H., cited --_-_-_-_-_-_-_ 25

pentodon, Gastrocopta

Petersburg Formation, Indiana--_-_-_-_-_-_-_

Petty's Ford, Little Vermilion River, Ill-_-_------25

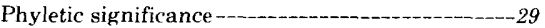

Physidae -

picta, Anguispıra --_-_-_-_-_-_ 8,$9 ; \mathrm{pl}, 3$

Pilsbury, H. A., cited-_-_-_ 3, 7, 8, 21, 28 quoted -._-_._- 12, 20

Pineria -

Planogyra -

Planorbidae-_-_-_- 30

Plant bed No. 2, Fern ledges, St. John,

New Brunswick-_. 6, 7

Plant beds, below coal No. 6, Petty's Ford, Vermilion River, Ill. --_-_-

Erian -...--_-

St. John, New Brunswick --_-_-

Plants, arborescent -_-_-_-_33

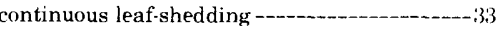
laminate foliage -

Pleasant Grove, Belmont County, Ohio--_-_-_-_- 5 Belmont County, Ohio, Permian rocks --_--_--. 3

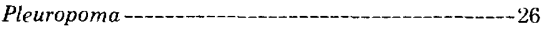

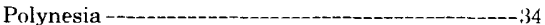

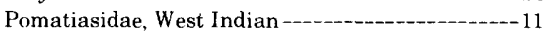

Poole, E. G., cited -

Potamopyrgus --..--

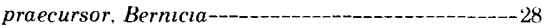

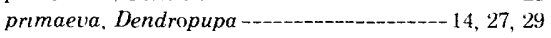
Pupa - - 2, 3, 7, 14

priscus, Archaeozonites --_-_-_-_-_-

Protodiscus --_-_-__-_-_-_._.-_29 pls. 2, 8
priscus-Continued

Page

Pyramidula-

$----7$

Zonites --__-_- $3,7,8,9$

(Conulus) --

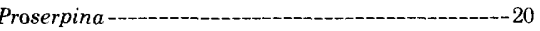

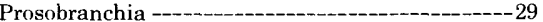

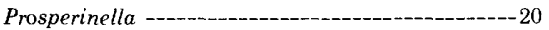

Proserpininae---_-

Prosobranch, thiarid---_-_-_ 2, 10, 28, 31, 34

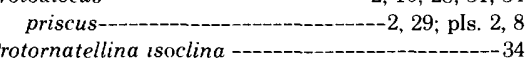

Pruvost, Pierre, cited --

Pseudhelicinia-_-_-_-_-_-_-_-_-_-_-_ 26, 33

Psuedosigmurethrous features--_-_--_-_-_-----31

Pterodactyl ---_-

Pulmonata---_-_._- 29

Pulmonate---_-_-_-_-_-_-_ 21

Punctidae-----_--_-.-

minutissionum --_-_-

Pupa begsbil -_-_ 2, 3, 6, 19

bigsbyi - 29, 31,$34 ;$ pls. 2,8

primaeva ----_-_-_-_-_-_, $3,7,14$

vermilionensis $\ldots-3,4,5,20,24 ;$ pl. 1 vetusta tenuistriata--_-

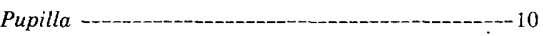

Pupillacea ----_-_-_-_-_-_-_-_---- 10, 12, 29, 31, 34

Pupillidae--_-_-_-_- 3,20 distribution -

Pupilloid, growth pattern--
Pupilloid, sculpture -21

Pupilloid, sculpture
pusilla, Lamellidea-

Pyramidula--

$$
\text { priscus }
$$

Pythia -

-

\section{$\mathrm{R}$}

Radiodiscus-------

Rain forest areas-_-

Redpath Museum, collection--_-_-_-_-_- 6

References cited---_--_36

Reisner Limestone Member, Mattoon Formation -- 5

rothenburgensis. Anthracopupa-_-_-----23, 26, 27

Runnegar, Bruce, cited --_-_-_-_- 28

Russell, L. S., quoted -

\section{$\mathrm{S}$}

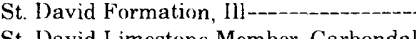

St. David Limestone Member, Carbondale

Formation -.-

Saône-et-Loire---_-_-_- 66

Schasicheila---

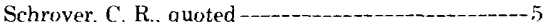

scotica, Carbonispira-_-_-_-_-_-

Scott's Cut, Belmont County, Ohio -

Scremerston Coal Group --

Scremerston, Northumberland, England-_-_-_----28

Siglllaria --_-_- 6

Sigmurethra -- 29, 31

Slugs - - - 1

Snail, planorbiform, Madagascar--_-_.....---- $2 \gamma$

Snails, freshwater-30, 31

freshwater, Paleozoic-_-

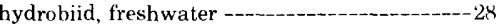

Paleozoic nonmarine --_-_-_-_-_._-_._--26

Sukhona-Mezen Rivers area, Vologda region,

Moscow-

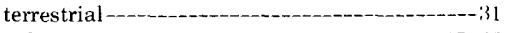

Spirorbis---_-_-_-_ 24, 25, 27 Spring I ake Coal Member, Carbondale Formation-4 Staesche, Karl, cited --_Stauffer, C. R., quoted--

Stenotrema leal -

Stratigraphic correlations, North America

and Europe --_-

Striatura--
Strophella-Continued Page

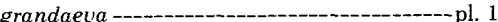

grandaevus ---------

Strophites --_-_---_--- 3,13

grandaeva--_-_-_-_-_-_-_ 3,15

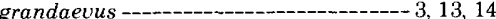

sturgeoni, Anthracopupa---------- 2, 23, 26, 29; pl. 9

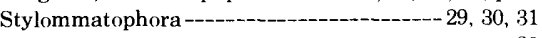

origin---_-

12, 21

Sukhona-Mezen Rivers area, Vologda region,

Moscow-- 27

Summum coal, Coal No. 4---_-_-_-_-_-_- 4, 5

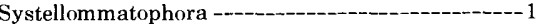

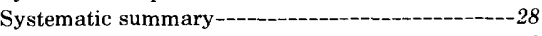

Systematic work, earlier--

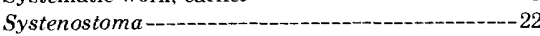

\section{$\mathrm{T}$}

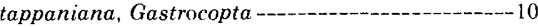

Taxa, analysis ---

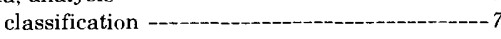

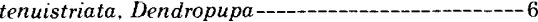

Dendropupa vetusta--_-_-_-_-_-_-_-_-_-_-_10

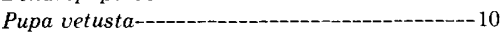

Terrestrial strata, New Brunswick--_-_-_-_-- 3

Top Hosie Limestone-------------------28

Tornatellides oblongus -...--_-_-_-_-_-_-_----23

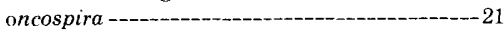

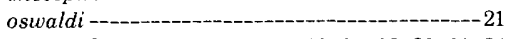

Tornatellinidae -----------3, 10, 12, 20, 23, 29, 31, 34

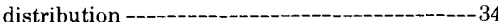
speciation centers ---

Tornatellinoid, growth pattern -----------------21

Tortacella-----

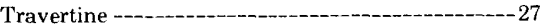

Tree stumps --- 6,31

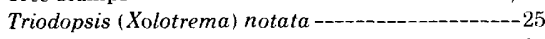

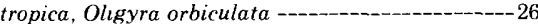

\section{$\mathrm{U}$}

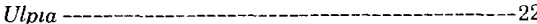

Unio--_-

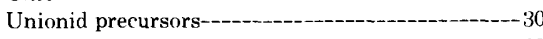

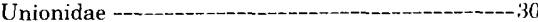

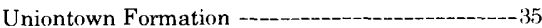
Dunkard Group --Monongahela Group --_-_._- 35

Uniontown Limestone Member ----------- 23, 24

Uniontown Limestone Member.

Uniontown Formation --_-_-_----- 2:3, 24

Upper Washington Limestone Member,

Washington Formation --_-_-_-

Uptown borehole, Oxfordshire, England ---_-_---26

Urocoptid stock, Antillean -------- 12, 1;

Urocoptidae-- 3, 12, 21,29 convergences --

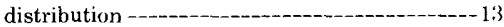
growth pattern--origin-----

\section{V}

Valvatidae--...-

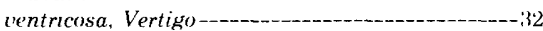

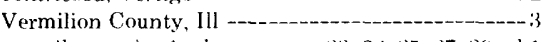

cermilionensis, Anthracopupa-23, 24, 25, 27, 29; pl.1

Maturipupa----_-

Pupa -_-_-_ 4, 5, 20, 24; pl. 1

Vermilionville Sandstone Member-.....

Vertigo ----morset--.-ventricosa -

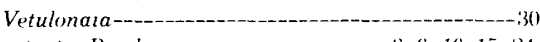

l'etusta, Dendropupa $26,27,29 ;$ pls. 4,8

Dendropupa le'tusta-_-_-_-_-_o Pupa tenuistrata, Dendropupa ---_-_-_- 10

Pupa -

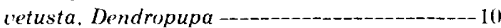


Page

Vitrina limpida

Viviparidae -

Vologda region, Russia--

\section{W}

walchiarum, Dendropupa ---------_------- 14, 26, 27

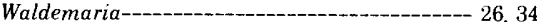

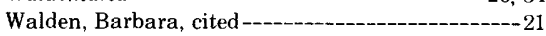

Washington Formation, Dunkard Group---------5

Iower limestone member--.----

Lower Washington Limestone Member-16, 24, 35
Page

Washington Formation-Continued Upper Washington Limestone Member --.-.-.-35 Waterfowl, Australian--_-_-_-_-_-_-_-_-_------30

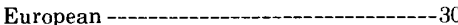

Waynesburg Formation, Dunkard Group ----------35

Weber, Jon, cited--_- 27

Weller, J. M., cited --_-_-_-_-_-_-

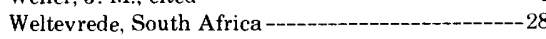

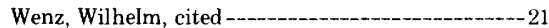

White, C. A., cited-

Whitfield, R. P., cited------------------------- 4, 21 quoted

Worm tubes
Page

$$
\mathrm{X}, \mathrm{Y}, \mathrm{Z}
$$

(Xolotrema) notata, Triodopsis -

Yen, Teng-Chien, cited --_-_-- 3, 7, 28

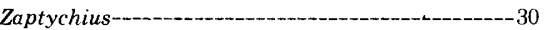
zareczyni, Dendropupa Zilch, Adolph, cited - - 3, 21

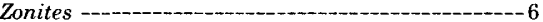
(Conulus) priscus -_-_-_-_-_-_-_-_-_--- 6, 7.9 priscus-_-_-_-_-_-_, $3,8,9$

Zonitidae - - -

Zonitoid, sculpture - 


\section{PLATES 1-10}

Contact photographs of the plates in this report are available at cost, from U.S. Geological Survey Library, Federal Center, Denver, Colo. 80225 


\section{PLATE 1}

[Figs. $1-3,5-22$ are $\times 15$; fig. 4 is $\times 5$ ]

Figures 1-3, 8-10, 13, 14, 18, 19. Anthracopupa ohioensis Whitfield, 1881, (p. 15).

1, 2. Side view of lectotype of Naticopsis (?) diminuta, OSU (Ohio State University) 15170 , probably the original of pl. 11, fig. 23 of Stauffer and Schroyer (1920). 3. Oblique side view of lectoparatype of N.(?) diminuta, OSU 15169, probably the original of pl. 11, fig. 22 of Stauffer and Schroyer (1920). Both specimens from "the shales at the base of the Lower Washington Limestone, one-half mile south of Pleasant Grove, Belmont County, Ohio" (Stauffer and Schroyer, 1920, p. 145). 8, 9. Oblique apical and side view of lectoparatype of A.(?) dunkardana Stauffer and Schroyer, 1920 (p. 15), OSU 15163, possibly the original of pl. 11, fig. 14 of Stauffer and Schroyer (1920). 10. Basal view of lectoparatype steinkern of $A$. (?) dunkardana, OSU 15162. 13, 14, 18, 19. Holotype, AMNH (American Museum of Natural History) 8487/1. From "Marietta, Ohio" (Whitfield, 1881, p. 126). 13. Side view. 14. Oblique apical view. 18. Oblique basal view, showing the thickened apertural lip. 19. Apertural view.

5-7. Anthracopupa vermilionensis (Bradley) 1872, p. 24.

5. Apertural view of Pupa vermilionensis Bradley, 1872, USNM (United States National Museum) 242,698. 6. Side view, USNM 242,699. 7. Side view with aperture broken back, USNM 242,700. All specimens out of USNM lot 27,600 labeled "Upper Carboniferous (Coal No. 6), four miles below Georgetown, Illinois."

4. Strophella grandaeva (Dawson, 1880) (p. 14). Side view of holotype Strophella grandaevus Dawson (1880) with light at an extremely low angle to emphasize the ribs, Redpath Museum 2384, from "plant-beds of St. John, New Brunswick" (Dawson, 1880, p. 413).

11-12. Anthracopupa(?) dunkardana Stauffer and Schroyer, 1920 (p. 15). Side and apertural views of lectotype of A.(?) dunkardana, OSU 15161, probably the original of pl. 11, figs. 12 and 13 of Stauffer and Schroyer (1920). All specimens from the same locality as specimens shown in fig. 1, this plate.

15-17, 20-22. ?Anthracopupa parva (Stauffer and Schroyer) 1920 (p. 24). 15, 20. Apical and apertural views of lectotype Loxonema(?) parva Stauffer and Schroyer, 1920, OSU 15165. This is the original of pl. 11, fig. 19 of Stauffer and Schroyer (1920). 16, 17. Slightly oblique side view and oblique apical view of lectoparatype Loxonema(?) parva, OSU 15166. This is the original of pl. 11, fig. 21 of Stauffer and Schroyer (1920). 21. Side view of broken lectoparatype Loxonema(?) parva Stauffer and Schroyer, 1920, OSU 15167. This is the original of pl. 11, fig. 20 of Stauffer and Schroyer (1920). 22. Side view of largest specimen, Loxonema(?) parva, lectoparatype OSU 15168; the original of pl. 11, figs. 17 and 18, Stauffer and Schroyer (1920); in those figures, the aperture was restored. All specimens from the same locality as specimens shown in figure 1 , this plate. 


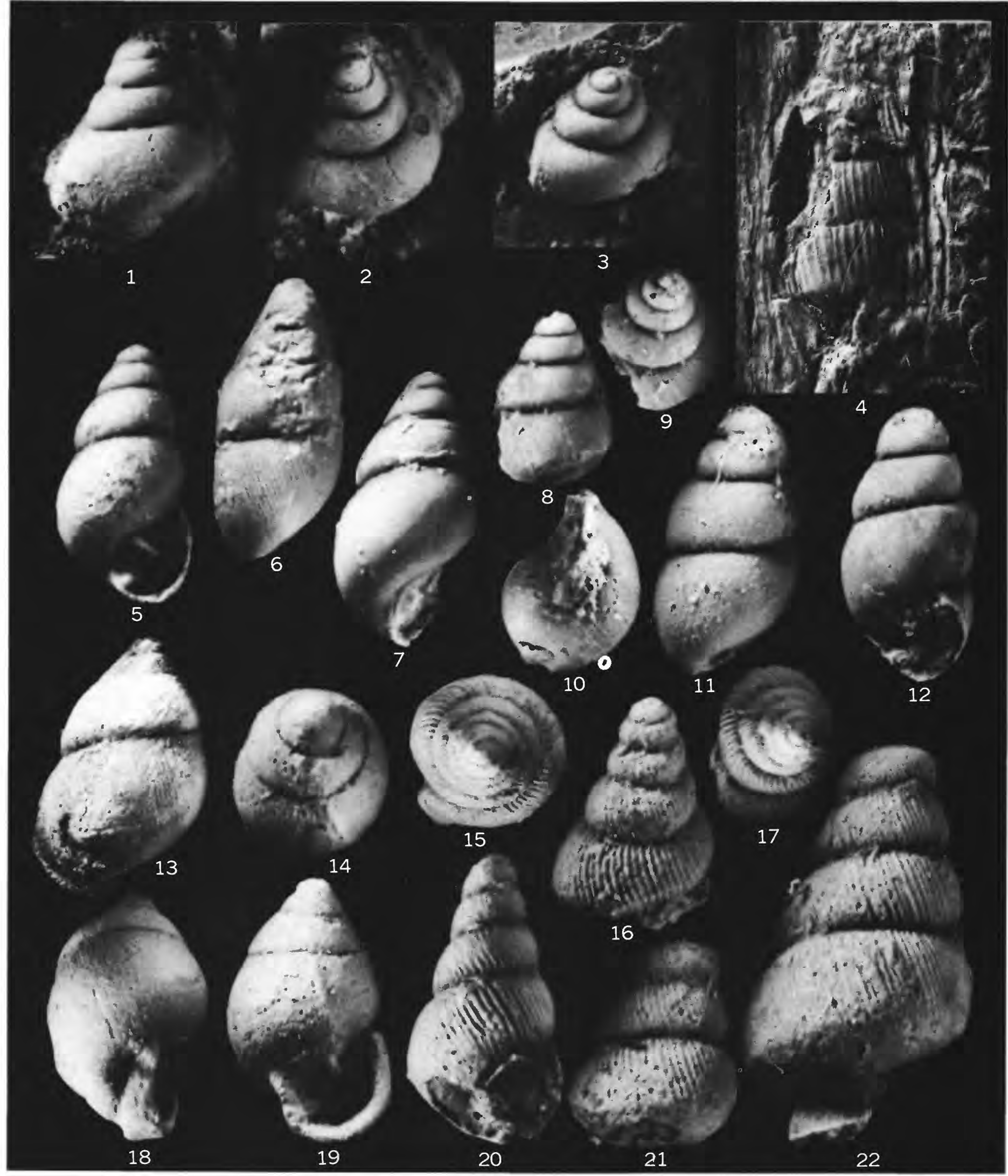

STROPHELLA, ANTHRACOPUPA (?), ANTHRACOPUPA, AND ?ANTHRACOPUPA 


\section{PLATE 2}

Figures 1-5. Protodiscus priscus (Carpenter, 1867) (p. 7).

1. ×31.6. Holotype. Coal Measures, Nova Scotia. Redpath Museum 3116. Original of Dawson's 1867 fig. b and 1880 fig. 10. 2-5. Paratype. Coal Measures, Nova Scotia. Redpath Museum 3116b. 1. $\times 31.6$. Oblique apical view of entire shell, partly crushed. 2 . $\times 98$. Apical and early postapical sculpture. $3 . \times 92$. Low-angle view of sculpture, apical left, postapical right. $4 . \times 184$. Detail of apical sculpture. 5. $\times 475$. Detail of spiral postapical sculpture near the suture.

6. Pupa bigsbii Dawson, 1880 (p. 9). Lectotype. Erect trees of Group XV, Coal Measures, South Joggins, Nova Scotia. Redpath Museum 3122. Apertural view of entire shell. $\times 42.6$. 

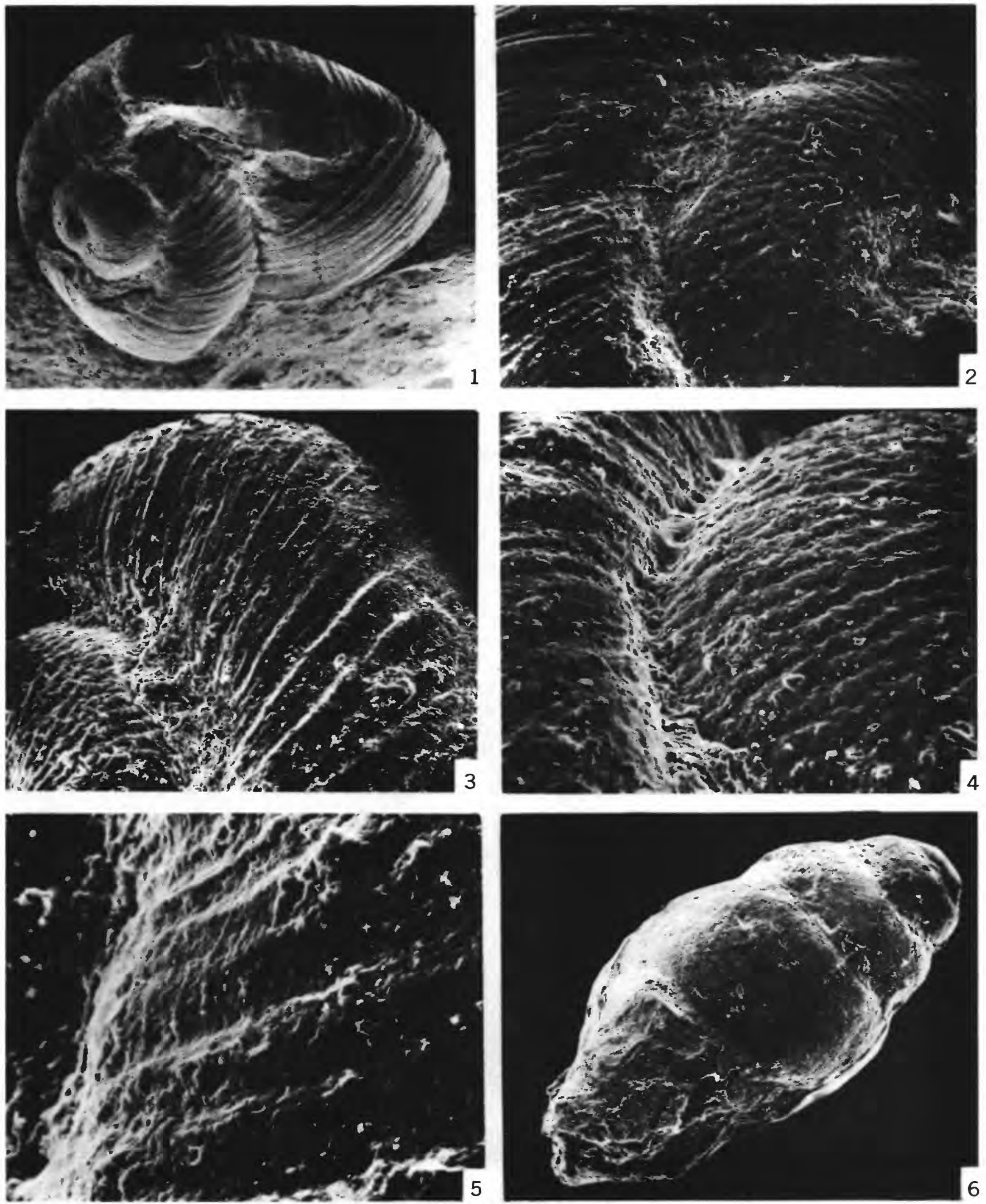


\section{PLATE 3}

Figures 1-6. Anguispira picta (Clapp, 1920) (p. 8). Buck Creek Cove, south of Sherwood, Franklin County, Tennessee. Glenn Goodfriend. Sept. 6, 1974. FMNH 171138.

1. $\times 72$. Apical boundary area. 2. $\times 229$. Detail of oblique microsculpture at end of apex. 3 . $\times 22.6$. Early whorls of juvenile shell. $4 . \times 112$. Midapical area having radial elements well developed, but oblique microelements absent to weakly developed. $5 . \times 112$. Apical transition between microsculpture only, and radial elements present. 6. $\times 228$. Detail of oblique microsculpture. 

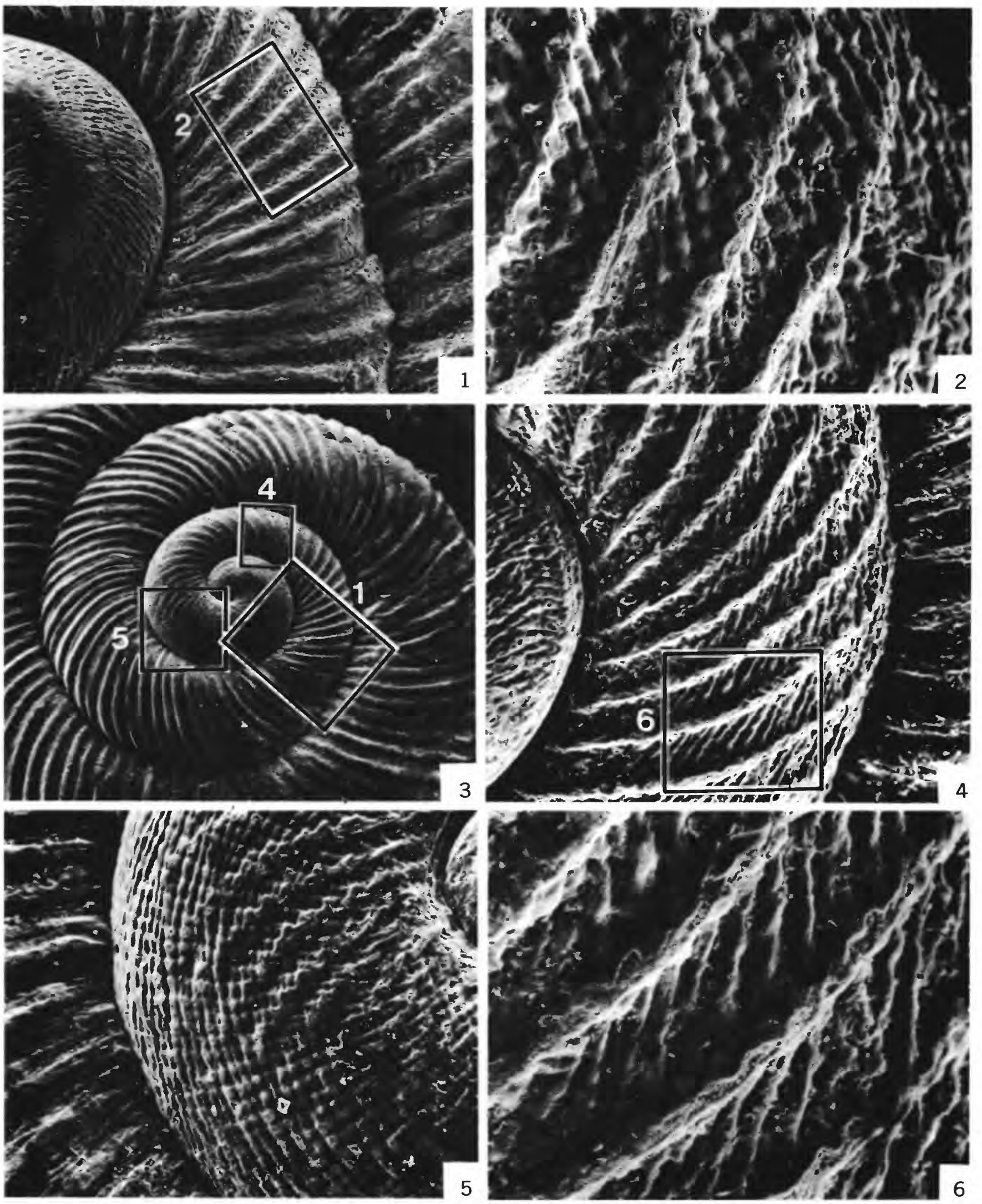


\section{PLATE 4}

Figures 1-6. Dendropupa vetusta (Dawson, 1855) (p. 10).

1. X21.8. Coal Measures, Joggins, Nova Scotia. Redpath Museum 15.011. Partly embedded shell having $51 / 4$ whorls preserved. 2 . $\times 116$. Redpath Museum 15.011. Details of apical (right) and first postapical whorl sculpture. $3 . \times 174$. Redpath Museum 15.007. Suture on spire of a shell fragment. 4. $\times 571$. Redpath Museum 15.011. Fracture through fossil showing recrystallization. 5. $\times 2,200$. Redpath Museum 15.011. Detail of recrystallization. 6. $\times 79$. Redpath Museum 15.012. Detail of body whorl behind expanded lip. 

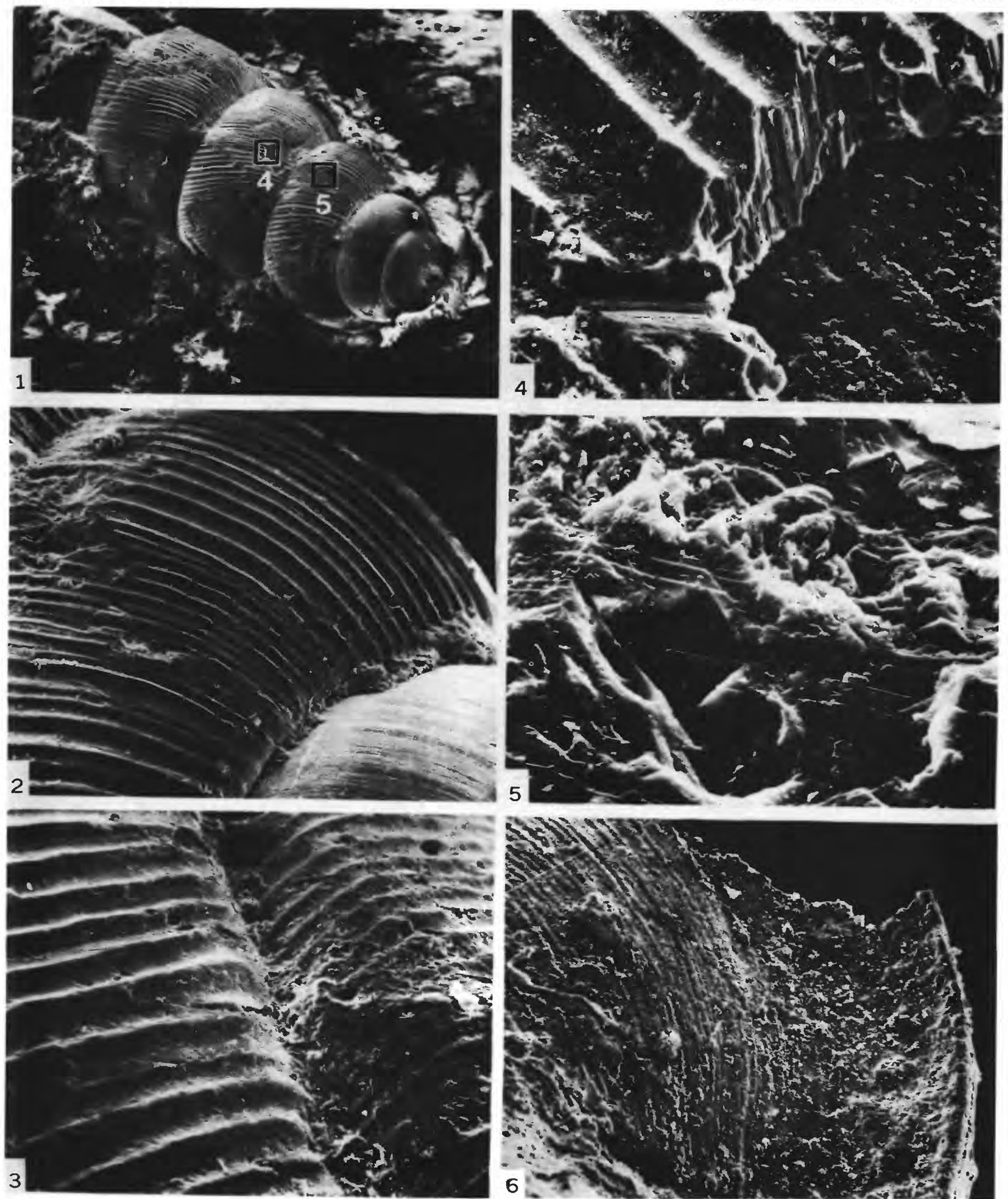


\section{PLATE 5}

Figures 1-6. Anthracopupa ohioensis Whitfield, 1881 (p. 15). "Lower Washington Limestone Member," Washington Formation, Ayers limestone quarry in SW $1 / 4$ sec. 19, Pease Twp., Belmont County, Ohio. USGS 24855-PC (USNM 242, 701).

1. $\times 18.9$. Apertural view. Entire shell, surface sculpture eroded. $2 . \times 49$. Gerontic aperture. 3 . $\times 89$. Detail of right part of aperture. $4 . \times 178$. Parietal barrier, showing crevice left by dissolved periostracum. 5 . $\times 872$. Break on outer surface of parietal barrier. $6 . \times 4,300$. Microcrystals on surface of parietal wall and barrier. 
GEOLOGICAL SURVEY
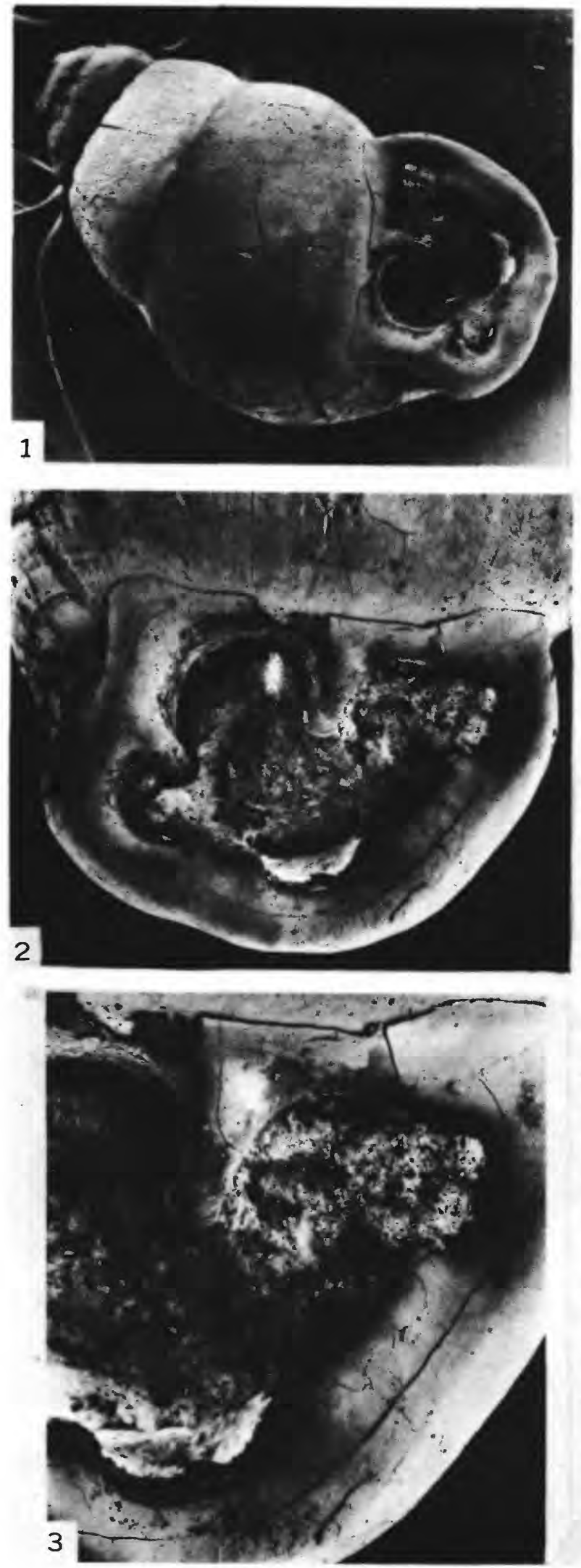

PROFESSIONAL PAPER 1072 PLATE 5
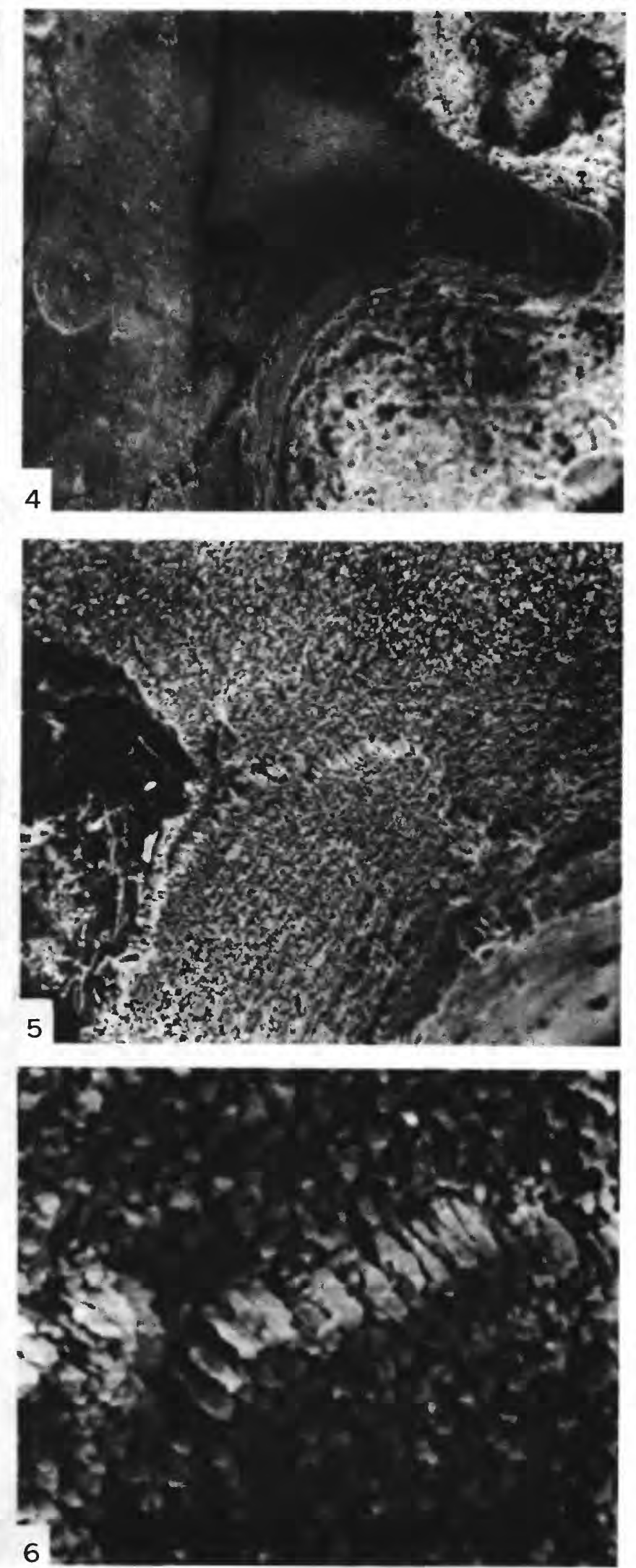


\section{PLATE 6}

FigurEs 1-6. Anthracopupa ohioensis Whitfield, 1881 (p. 15). "Lower Washington Limestone Member," Washington Formation, Ayers limestone quarry in SW $1 / 4$ sec. 19, Pease Twp., Belmont County, Ohio. Juvenile specimens. USGS 24855-PC.

1. $\times 51$. Sculpture on shell surface. USNM 242,702. 2. $\times 205$. Apical (upper left) and postapical sculpture. 3. $\times 64$. Juvenile aperture. $4 . \times 89$. Detail of aperture. $5 . \times 33$. A narrower juvenile shell. USNM 242,703. 6. ×77. Detail of aperture showing bilayered nature of lip at bottom. 

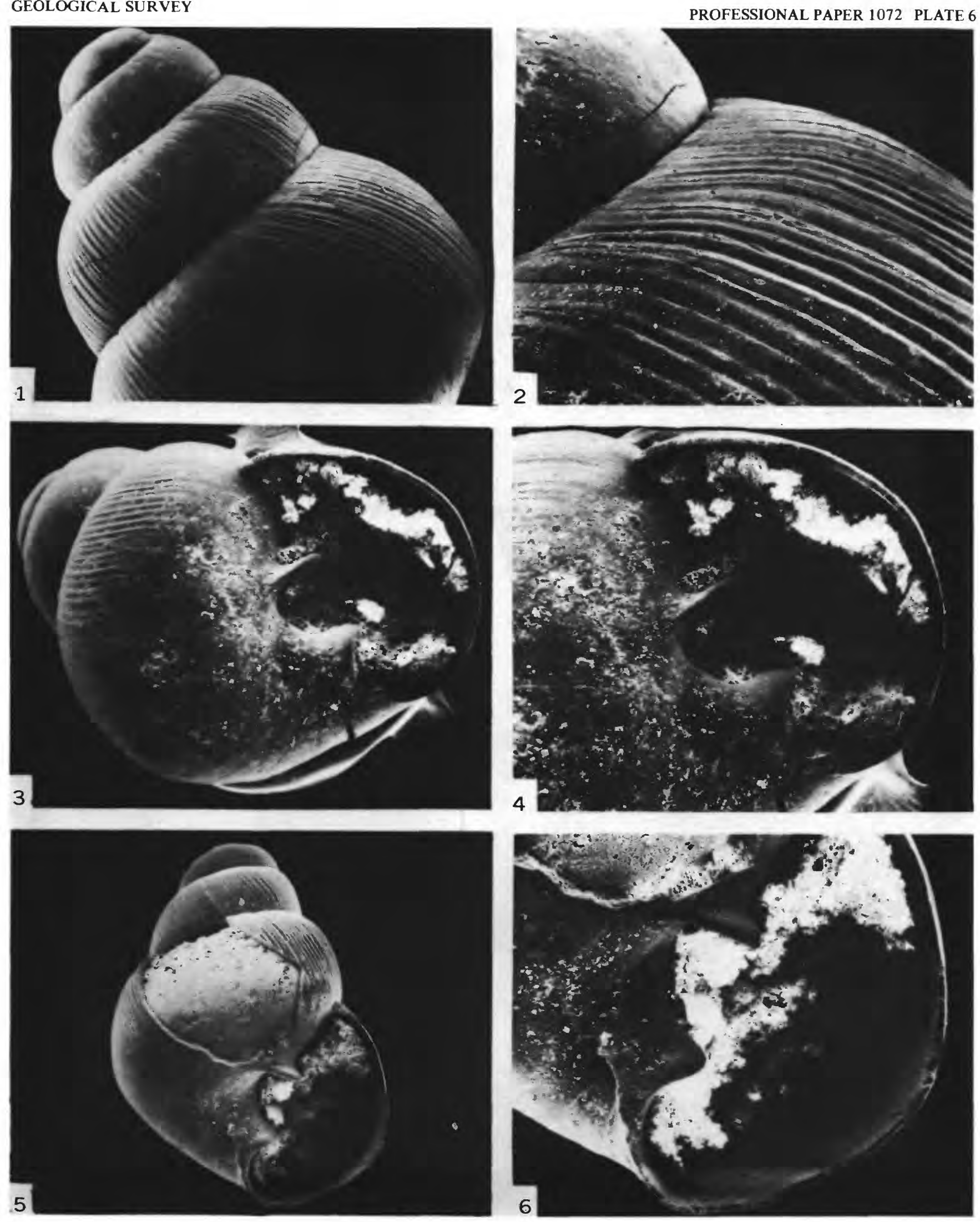


\section{PLATE 7}

Figures 1-6. Anthracopupa ohioensis Whitfield, 1881 (p. 15).

1-4. "Lower Washington Limestone Member," Washington Formation, Ayers limestone quarry in SW 1/4 sec. 19, Pease Twp., Belmont County, Ohio. USGS 24855-PC. (Barrier lost; remainder of specimen, USNM 242,704.) 1. $\times 138$. Excised parietal barrier, anterior margin at left. $2 . \times 1,326$. Side of barrier near posterior end showing change in size of microdenticles from side to top of barrier. 3. $\times 1,695$. Microprojections on top of parietal barrier. 4. $\times 9,764$. Details of individual microprojections on barrier top.

5-6. Basal part of Little Captina Limestone Member, Monongahela Formation, ravine on north side of Deep Run Road, extreme west sec. 26, Pease Twp., Belmont County, Ohio. USGS 24836-PC. (Specimen lost.) 5. $\times 171$. Anterior end and upper edge of columellar barrier. 6. $\times 888$. Microprojections on barrier (right) and matrix crystals. 

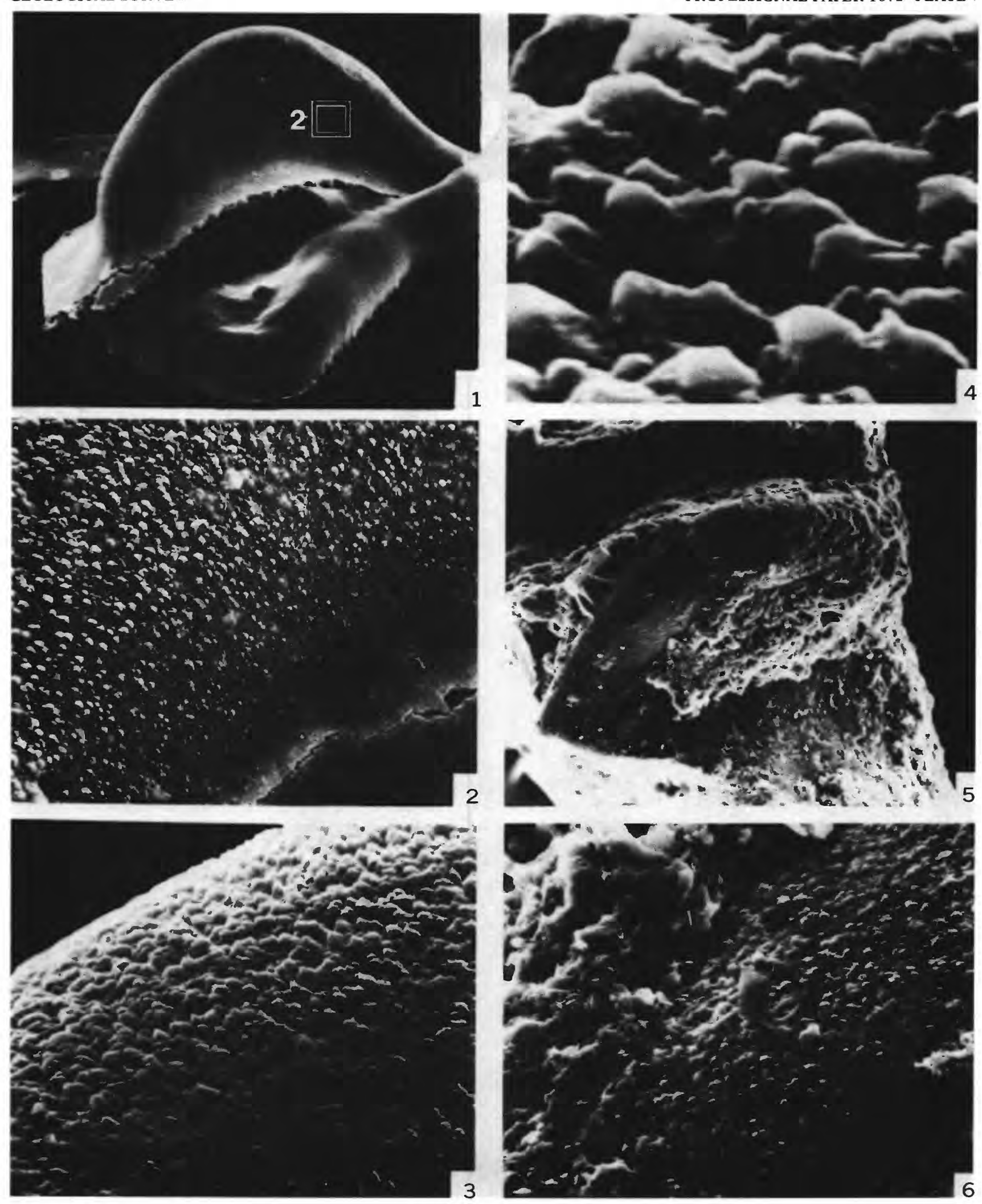


\section{PLATE 8}

Figures 1, 2. Protodiscus priscus (Carpenter, 1867) (p. 7). Coal Measures, South Joggins, Nova Scotia. Paratype. Redpath Museum 3116a. Basal view of shell.

1. $\times 21.3$. View from basal angle. $2 . \times 22.2$. View from apical angle.

3, 4. Anthracopupa sp. (p. 10). Paratype of Pupa bigsbii Dawson, 1880. Redpath Museum 3122a. Coal Measures, South Joggins, Nova Scotia. $3 . \times 42.5$. Side view. Note remnant radial ribbing at upper left. 4 . $\times 58$. View of worn side of apex.

5. Dendropupa vetusta (Dawson, 1885) (p. 10). Coal Measures, South Joggins, Nova Scotia. Redpath Museum 15.010. $\times 50$. Isolated columellar fragment showing the two raised ridgelike barriers on surface. 

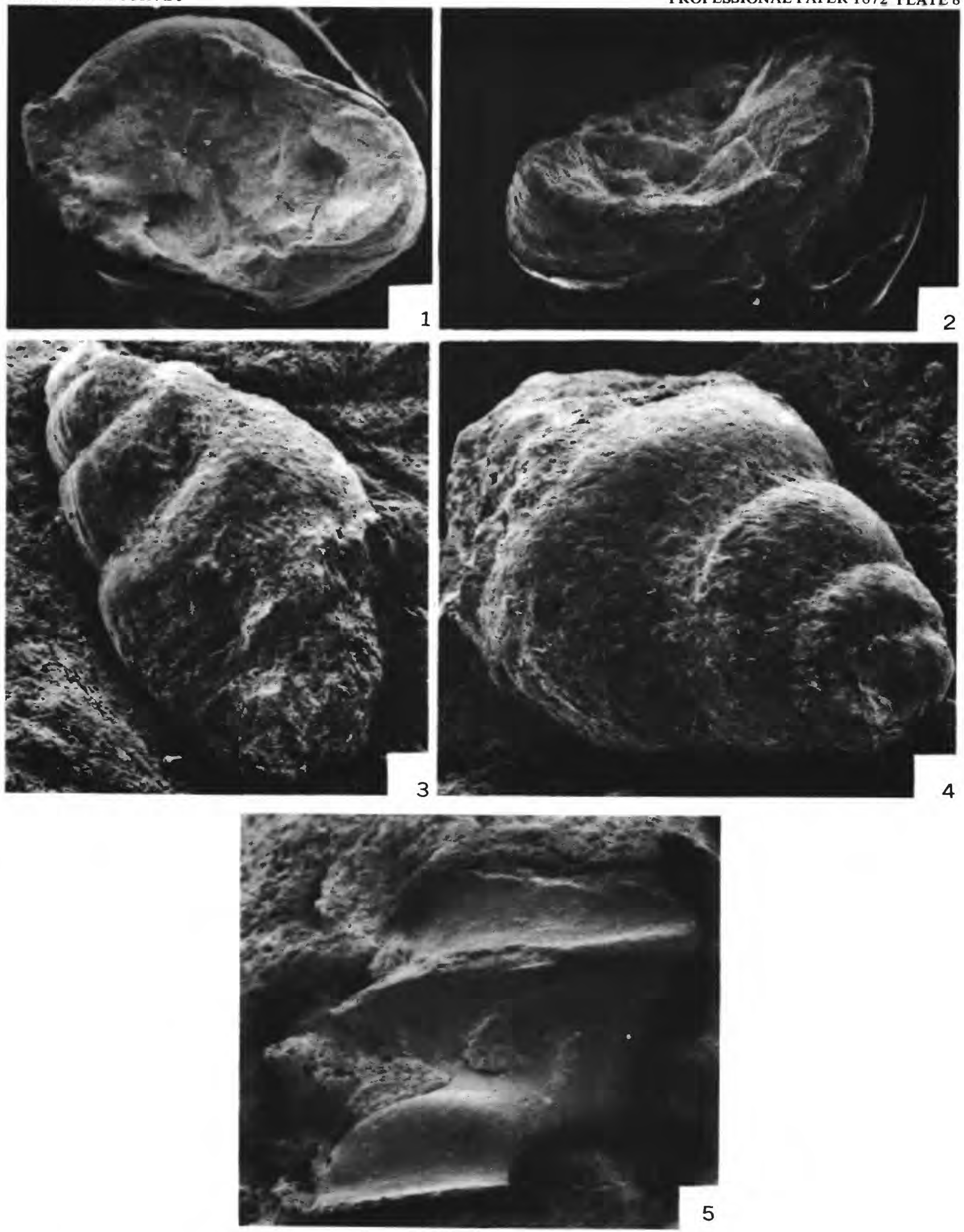

PROTODISCUS, ANTHRACOPUPA, AND DENDROPUPA 


\section{PLATE 9}

FiguRES 1-5. Anthracopupa sturgeoni Solem and Yochelson, n. sp. (p. 23). Little Captina Limestone Member, Monongahela Formation, in ravine on north side of Deep Run Road, extreme west sec. 26, Pease Twp., Belmont County, Ohio.

1-3, 5. Holotype. USGS 24836-PC. (USNM 242,705).

1. $\times 31$.5. Apertural view of entire shell. $2 . \times 59$. Detail view of aperture. $3 . \times 56$. Lateral view of aperture. 5. $\times 114$. Detail of shell sculpture on spire.

4. Paratype. USGS 24836-PC. (USNM 242,706). ×34.5. Apical fragment.

6. Anthracopupa ohioensis Whitfield, 1881. (p. 15). Nineveh Limestone Member, Greene Formation, center SW $1 / 4$ sec. 16, Salem Twp., Monroe County, Ohio. USGS 24827-PC. (USNM 242,715). X112. Shell sculpture on spire for comparison with sculpture of $A$. sturgeoni. 

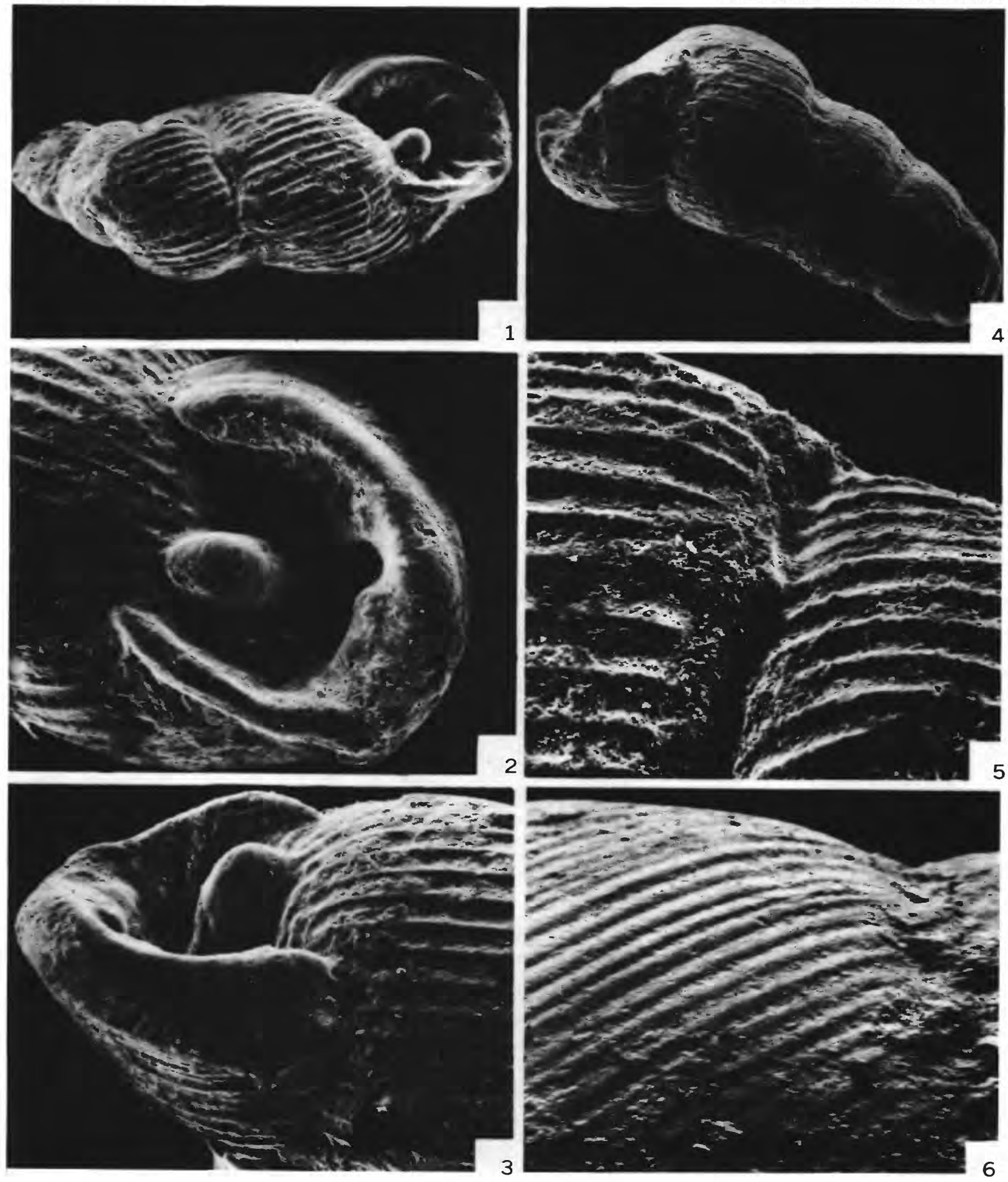


\section{PLATE 10}

Figures 1-6. Dawsonella meeki (Bradley, 1872) (p. 25). Petty's Ford, Little Vermilion River, below Georgetown, Vermilion County, Illinois FMNH 11673 from the Gurley Collection.

1. $\times 38.9$. Aperture. 2. $\times 42.3$. Lateral view of aperture to show basal-columellar projection. 3. $\times 107$. Sculpture on base of shell. $4 . \times 100$. Upper surface of shell showing broken layers. 5. $\times 997$. Detail of broken shell layer. $6 . \times 4,985$. Detail of crystal pattern in upper broken layer. 

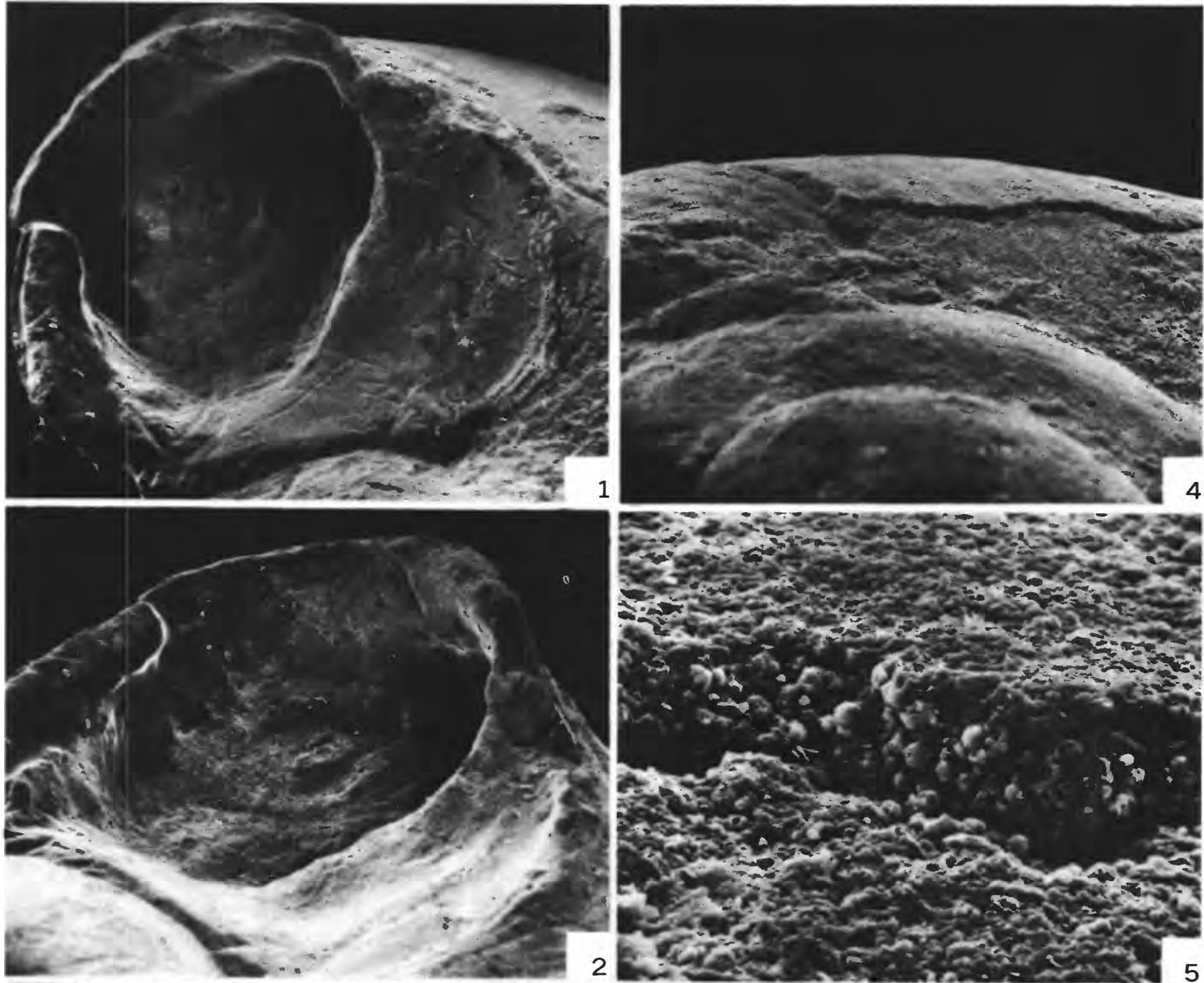

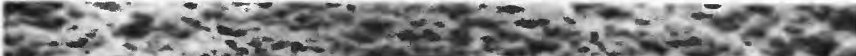

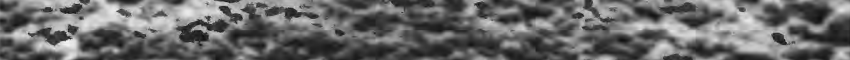

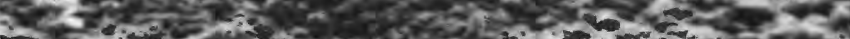

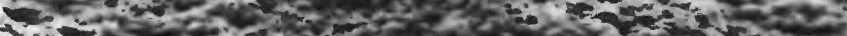
x.

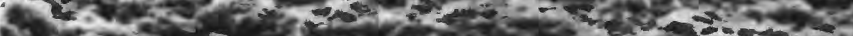

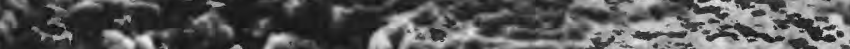

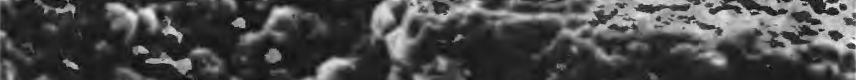
$\rightarrow x^{3}-2,5 E^{2}$
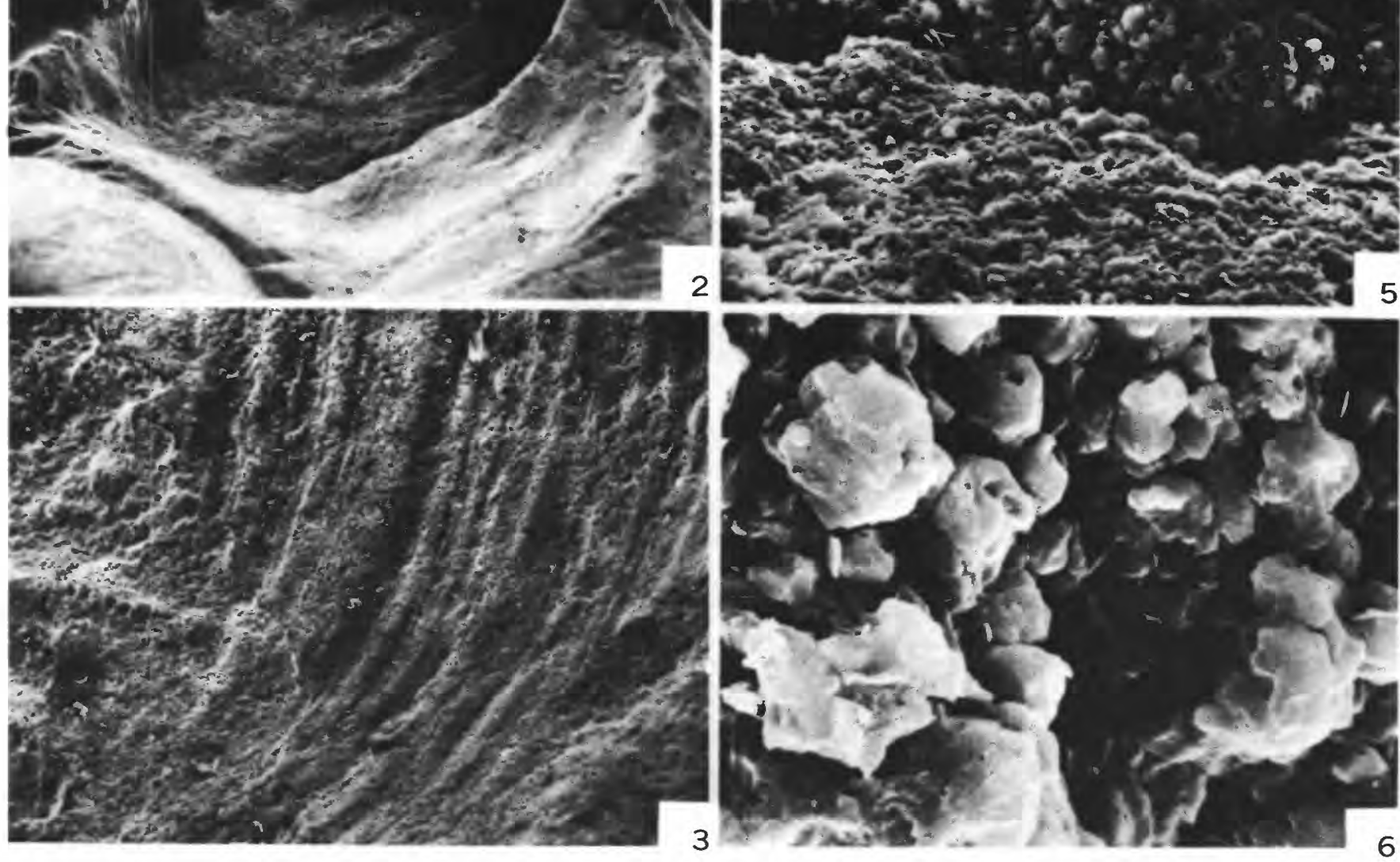